Dissertação de Mestrado apresentada à Banca Examinadora do Programa de Mestrado em Direitos Humanos e Cidadania da Universidade de Brasília (UnB), como requisito parcial para a obtenção do título de Mestre em Direitos Humanos e Cidadania.

Orientador: Prof. Dr. Wellington Lourenço de Almeida 


\section{Uma agenda possível? Desenvolvimento e direitos humanos no PNDH-3 e o neodesenvolvimentismo brasileiro}

Dissertação de mestrado apresentada à Banca Examinadora do Programa de Pós-Graduação em Direitos Humanos e Cidadania do Centro Avançado de Estudos Multidisciplinares da Universidade de Brasília ï UnB, como requisito parcial para a obtenção do título de Mestre em Direitos Humanos e Cidadania.

Orientador: Prof. Dr. Wellington Lourenço de Almeida

Banca Examinadora:

Prof. Dr. Wellington Lourenço de Almeida (Orientador) PPGDH ï CEAM

Profa. Dra. Vanessa Maria de Castro PPGDH ï CEAM

Profa. Dra. Magda de Lima Lúcio PPGDSCI ï CEAM

Brasília, Dezembro de 2014. 


\section{AGRADECIMENTOS}

Conhecer é existir. Sem cartesianismo: é como estabelecemos vínculos com o mundo: conhecemos o mundo que nos cerca, e das mais distintas maneiras: imagens, texturas, gostos, sonoridades, pensações, imaginações. Conhecer é sentir. É perceber-se. E interagir.

Quero aqui registrar as interações, tão importantes quanto a solidão. Enquanto as primeiras são eventuais, acontecem e passam, a segunda é o estado permanente, necessário ao conhecimento (ao autoconhecimento). Decifra-te a ti mesmo.

A pesquisa acadêmica é um processo silencioso e por vezes ruidoso, que decepa algumas colunas de certezas e alicerça outras pontes, que nos levam a outras margens. Além da reflexão solitária, há as pessoas que estão em nossas pontes, para dar suporte, fazer a vida ganhar sentido, estimular os sentidos, aguçar as percepções, proporcionar travessias (e travessuras).

É a elas que me reporto. Agradeço ao meu orientador, Wellington Lourenço de Almeida, pela compreensão constante, e pelos sempre gentis cafés regados a conversas sobre política.

Agradeço à Universidade de Brasília, e sobretudo ao Programa de Pós-Graduação em Direitos Humanos e Cidadania do CEAM, na pessoa de sua coordenadora, Professora Nair Bicalho, pelo espaço e oportunidade.

Não posso deixar de mencionar algumas pessoas que, após eu ter deixado um horizonte para trás e ter abraçado um cerrado de utopias, foram presentes ao longo desses dois anos de jornada. Pessoas-sentidos, indispensáveis ao conhecimento.

À acolhida. Clarice Calixto e Ricardo Horta, pela acolhida nesta Brasília de distâncias e pelo aprendizado nas duras engrenagens da máquina.

À utopia do lugar diferente, que nos faz mover todo dia. Às jovens companheiras do Bê e Dê, hoje Esquerda Libertária Anticapitalista Ï ELA, agradeço na pessoa do Rafael de Acypreste, que muita pilha colocou em uma cabeça ligada em inúmeros acontecimentos, e com vontade de tanto refletir sobre eles, para assumir esse projeto de fazer mestrado. Que a criatividade, a alegria e o amor sigam os passos das lutas dessas companheiras, por dias menos pesados nas vidas de tantas pessoas neste DF.

À compreensão. Anna Cláudia, pelo diálogo e incentivo à autonomia nas tarefas diárias: sua compreensão foi essencial para a realização desta pesquisa. 
e Maria Victoria Hernández, pela conversa receptiva,

transparente e expressiva, indispensável.

À amizade. Cleuber, pela troça diária, capaz de esboçar cenas almodovarianas sobre dias de concretude cinza e tediosa. Vinícius, por me mostrar que a leveza é aliada principal do entendimento e do presente. Rony e Yara, pela demonstração de que a maior inimiga da distância e da ausência é a fé. Menino Breno, por ter colorido minha vida no final dessa jornada, com a partilha das angústias, dos tempos sem tempo, e do burilar eterno de nossas existências. Natália Maria, mulher-verbo, capaz de corporificar a mais etérea das ideias. Rachel, Lygia e Alice, portos de graça do viajante sem descanso. Letícia, Danúbia, Debora, Carlos, Clara, Sueli, Marcos, Cleide, Julia, Ísis, Bárbara e Andreia: companheiras de ontem e de hoje da labuta acadêmica.

Dizem que não podemos entrar duas vezes no mesmo rio. Esta certeza do existir mutante, das pessoas que passam por nossas vidas e nelas deixam marcas, é o que de fato faz a vida valer a pena: seguir em frente, descobrir o novo, reinventar-se e se deixar marcar em cada dia. Deixo esse rio para atravessar outros rios, em busca da simples, porém árdua tarefa, de rolar a pedra morro acima, feito Sísifo. 
ñO desenvolvimento é realmente um compromisso muito sério com as possibilidades de liberdade.ò

Amartya Sen 


\section{RESUMO}

O Brasil tem observado, nesta última década, uma experiência híbrida de política econômica, que oscila entre concepções desenvolvimentistas, implementadas ao longo de sua modernização capitalista em boa parte do século XX, e de concepções neoliberais, vivenciadas sobretudo na década de 1990. Esse cenário misto de concepções econômicas aponta um projeto de crescimento com inclusão social, produzido do ponto de vista discursivo e das políticas públicas, como um projeto de desenvolvimento do país. Tal projeto recebeu o nome de neodesenvolvimentismo pela literatura recente, e sua implementação pode ser parcialmente explicada por uma dependência de trajetória da política econômica brasileira. Ao mesmo tempo, o conceito de desenvolvimento, estruturado ao longo da modernização capitalista mundial, contribuiu para a criação de exigência de fundo ético e universal: o direito humano ao desenvolvimento. Constituído como expressão recente dos direitos econômicos, sociais e culturais, afirmados em nível internacional, tal direito ganhou expressividade na teoria de Amartya Sen, que extrapolou o viés meramente econômico e o equiparou à liberdade humana com igualdade de capacidades. Esse quadro conceitual, global e histórico auxilia a compreensão da formulação da agenda política doméstica de desenvolvimento e direitos humanos, prevista no Programa Nacional de Direitos Humanos 3 ï PNDH-3. A pesquisa aqui proposta tem por objeto analisar, a partir desse quadro, o Eixo Desenvolvimento e Direitos Humanos no PNDH-3, com base em dados documentais e empíricos, obtidos em entrevistas com gestores responsáveis pela formulação do Programa. Conclui-se que a formulação da agenda escolhe, em nível pragmático e de forma adequada à convenção neodesenvolvimentista, as ações e projetos de reconhecimento do desenvolvimento como direito humano no Brasil.

Palavras-chave: Desenvolvimento, Direitos Humanos, Brasil, Política Pública, PNDH-3, Neodesenvolvimentismo, Desenvolvimentismo, Neoliberalismo, Amartya Sen. 


\section{ABSTRACT}

Brazil has been enduring, over the last decade, a hybrid experience of economic policy, ranging from developmentalist conceptions, implemented throughout its capitalist modernization during much of the twentieth century, and neoliberal conceptions, experienced mainly in the 1990s. This scenario combination of economic conceptions points towards a project of growth with social inclusion, produced through discursive perspective and public policy, as a development project for the country. This project received the name of neodevelopmentalism in recent literature, and its implementation can be partially explained by a path dependence of Brazilian economic policies. At the same time, the concept of development, structured along global capitalist modernization, contributed to the creation of an ethical and universal demand: the human right to development. Constitued as a recent expression of economic, social and cultural rights, and declared in international range, this right has gained expressivity on the theory of Amartya Sen, which surpasses the mere economic bias and matches it to human freedom with equal capabilities. The proposed research aims to analyze, from this conceptual framework, the Development and Human Rights axis in PNDH-3, based on documentary and empirical data obtained from interviews with managers who were responsible for the Programme formulation. This conceptual, global and historical context helps to understand the formulation of domestic policy agenda of development and human rights set forth in the National Human Rights Programme - PNDH-3. Therefore, it is concluded that the formulation of this agenda chooses, in pragmatic extent and suitable for neodevelopmentalist convention, the actions and projects of recognition of development as a human right in Brazil.

Keywords: Development, Human rights, Brazil, Public Policy, PNDH-3, Neodevelopmentalism, Developmentalism, Neoliberalism, Amartya Sen. 


\section{LISTA DE SIGLAS E ABREVIATURAS}

ABCD ï Designa o conjunto de Municípios de Santo André, São Bernardo do Campo, São Caetano do Sul e Diadema

Aids Ï Acquired Immune Deficiency Syndrom ï Síndrome da Imunodeficiência Adquirida

Bacen Ï Banco Central do Brasil

Bamerindus ï Banco Mercantil e Industrial do Paraná S/A

Banerj ï Banco do Estado do Rio de Janeiro

Banespa Ï Banco do Estado de São Paulo

BID ï Banco Interamericano de Desenvolvimento

BNDE ï Banco Nacional de Desenvolvimento Econômico

BNDES Ï Banco Nacional de Desenvolvimento Econômico e Social

BPC ï Benefício de Prestação Continuada

CADE ï Conselho Administrativo de Defesa Econômica

CMN ï Conselho Monetário Nacional

CSN ï Companhia Siderúrgica Nacional

CTEF ï Conselho Técnico de Economia e Finanças

DASP ï Departamento Administrativo do Serviço Público

FHC ï Fernando Henrique Cardoso

FMI ï Fundo Monetário Internacional

HIV ï Vírus da Imunodeficiência Humana

IBGE ï Fundação Instituto Brasileiro de Geografia e Estatística

IDH ï Índice de Desenvolvimento Humano

INSS $і$ Instituto Nacional do Seguro Social

LGBT ï Lésbicas, Gays, Bissexuais e Transgêneros

LRF ï Lei de Responsabilidade Fiscal

MDS ï Ministério do Desenvolvimento Social e Combate à Fome

MEI Ï Microempreendedor Individual

MSI İ Modelo de Substituição de Importações

ODM ï Objetivos de Desenvolvimento do Milênio

ONU ï Organização das Nações Unidas

Oxfam ï Oxford Committee for Famine Relief (Comitê de Oxford de Combate à Fome) 
PETI ï Programa de Erradicação do Trabalho Infantil

PIB ï Produto Interno Bruto

PIDESC ï Protocolo Facultativo dos Direitos Econômicos, Sociais e Culturais

PMDB ï Partido do Movimento Democrático Brasileiro

PNAA Ï Programa Nacional de Aquisição de Alimentos

PND ï Programa Nacional de Desestatização

PNMPO Ï Programa Nacional de Microcrédito Produtivo Orientado

PNUD ï Programa das Nações Unidas para o Desenvolvimento

PPA ï Plano Plurianual

Pronaf Ï Programa Nacional de Fortalecimento da Agricultura Familiar

PSDB ï Partido da Social-Democracia Brasileira

PT ï Partido dos Trabalhadores

PTB ï Partido Trabalhista Brasileiro

Selic İ Sistema Especial de Liquidação e Custódia

Sumoc ï Superintendência de Moeda e de Crédito

SWB ï Subjetive Well-Being (Bem-estar subjetivo) 
LISTA DE ILUSTRAÇÕES

1. ENTRE DESENVOLVIMENTISMO, NEOLIBERALISMO E NEODESENVOLVIMENTISMO: A FINA TRAMA DO DESENVOLVIMENTO BRASILEIRO.

1.1 Introdução. Origem e breve conceituação.

1.2 Historicizando o neodesenvolvimentismo. Notas e inflexões políticas. .23

1.2.1 1930-1964: o primeiro ciclo do desenvolvimentismo brasileiro .24

1.2.2 O segundo ciclo de formação do desenvolvimentismo brasileiro: 1964-1980..... .29

1.2.3 A decadência do modelo desenvolvimentista e a ascensão do neoliberalismoé .33

1.2.4 Uma trajetória dependente: a hibridização do neodesenvolvimentismo .43

1.3 Conclusão .56

2. O DIREITO AO DESENVOLVIMENTO: DO ANSEIO PERIFÉRICO À

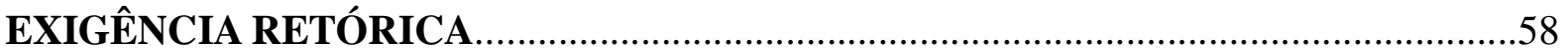

2.1 Introdução. 58

2.2 Desenrolar as amarras do passado e do presente: a ideia de desenvolvimento. .59

2.3 Desenvolvimento como liberdade: uma tarefa de conceituação. .68

2.4 Direitos humanos econômicos e sociais: desenvolvimento como imperativo, retórica

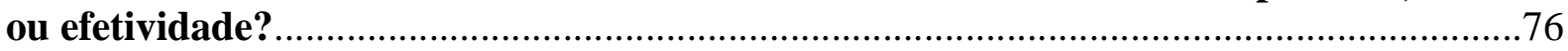

2.5 Um debate global. A agenda internacional do direito ao desenvolvimento................81

2.6 Conclusão

3. UMA PROPOSTA DE DESENVOLVIMENTO NUMA POLÍTICA DE DIREITOS HUMANOS: O PNDH-3.

3.1 Introdução.

3.2 A agenda política dos Direitos Humanos: os Programas Nacionais de Direitos Humanos.

3.3 O governo Lula e o contexto de formulação do PNDH-3. 102

3.4 O PNDH-3 e uma inovação: o direito ao desenvolvimento. 108 
5. REFERÊNCIAS 124

6. APÊNDICES 132

6.A Eixo Desenvolvimento e Direitos Humanos do Programa Nacional de Direitos Humanos 3 132

6.B Roteiro de perguntas realizadas nas entrevistas. 150 


\section{LISTA DE ILUSTRAÇÕES}

Figura 1: Quadro comparativo dos aspectos gerais da economia brasileira entre os dois ciclos do desenvolvimentismo

Figura 2: Evolução Histórica do Produto Interno Bruto Brasileiro (1995-2010). .46

Figura 3: Ciclo ñvirtuosoò de inclusão de renda e crescimento econômico. .50

Figura 4: Quadro dos principais conceitos da teoria do desenvolvimento como liberdade. $.74 / 75$

Figura 5: Expansão do Produto Interno Bruto Mundial, 1986-1999.

Figura 6: Distribuição do rendimento. Participação do quintil dos $10 \%$ superior no total da renda nacional (1995-2009). 106

Figura 7: Correlação de Ações do Eixo Desenvolvimento e Direitos Humanos do PNDH3 e Programas de Governo instituídos em governos antecessores. 


\section{ONSIDERAÇÕES METODOLÓGICAS}

A partir do início da primeira década deste século, o Brasil iniciou uma trajetória de ampliação das chamadas capacidades estatais, conforme apontam Gomide e Pires (2014). O Estado brasileiro, num contexto favorecido pela ampliação da oferta de crédito, aumento da renda salarial dos trabalhadores, sistematização e universalização de programas de transferência condicionada de renda para erradicação da pobreza extrema, aumento de reservas internacionais (com ganhos de exportação decorrentes dos aumentos de preços internacionais das commodities) e maior robustez fiscal, expandiu sua capacidade de formular políticas públicas e de implementá-las. Isso permitiu uma ampliação consequente de acessos, por diferentes parcelas da população brasileira, de serviços públicos, e contribuiu à formação ï sobretudo em nível discursivo $\ddot{i}$ de um projeto de crescimento econômico com inclusão social.

Essa apropriação discursiva da realidade construiu um projeto de desenvolvimento do país que, embora ressaltasse diferenças importantes de condução da política econômica, em comparação aos governos de tônica neoliberal, viu-se limitada, no nível mais pragmático, por concepções monetaristas, típicas dessa mesma tônica neoliberal, de gestão do capitalismo. A fixação de um tripé formado por câmbio flutuante, superávit primário e metas de inflação passou a ditar os rumos dessa gestão capitalista, fosse ela de caráter neoliberal ou não.

A ampliação de capacidades estatais e maior financiamento da produção pelo Estado, associados à vinculação pregressa, dependente, do Estado, a compromissos e exigências dos agentes de mercado em nível internacional, proporcionaram uma atuação oscilante do Estado na condução da política econômica $і ̈$ e também social ï o que foi batizado pela literatura recente (ARBIX E MARTIN, 2010; BOITO JR., 2003; ERBER, 2011); de neodesenvolvimentismo, numa afirmação mais ajustada à realidade que o termo novodesenvolvimentismo, cunhado por Bresser-Pereira (2003) e trabalhado por João Sicsú (2005).

Diante desse cenário, marcado pela relativização conceitual a ajustamento pragmático (decorrente de escolhas políticas) na gestão do capitalismo brasileiro, partem as questões fundamentais à investigação que deu origem a este trabalho: que concepção de desenvolvimento está no cerne desse projeto neodesenvolvimentista? Afinal, em que medida essa concepção de desenvolvimento se adequa a - ou se tensiona com - o projeto neodesenvolvimentista?

Para responder essas perguntas, fizemos algumas escolhas. A primeira diz respeito ao próprio objeto de investigação: elegemos uma política pública que trata do tema do 
Direitos Humanos 3 - PNDH-3, conjunto de ações de caráter transversal, com uma importante trajetória de consolidação na democracia brasileira, e que visa se tornar uma agenda permanente do próprio Estado brasileiro. O texto das ações do Programa está estruturado em torno de seis eixos orientadores, dentre os quais se encontra o eixo Desenvolvimento e Direitos Humanos, inovador em comparação aos outros dois programas nacionais de direitos humanos (PNDH-1 e PNDH-2), e que abarca um conjunto de ações diversas, voltadas à promoção do desenvolvimento enquanto direito humano. Por se tratar de um texto elaborado no final do segundo mandato do Presidente Luiz Inácio Lula da Silva (elaborado em 2008, publicado em 2009 e ajustado em 2010), está inserido em um contexto de vigência das concepções e ações neodesenvolvimentistas do governo federal, e de disputa política pelo próprio significado de desenvolvimento enquanto direito humano.

A segunda escolha que fizemos diz respeito à concepção teórica de desenvolvimento para a análise das ações do PNDH-3. Como marco teórico da investigação está parte da obra de Amartya Sen. Em Desenvolvimento como Liberdade (SEN, 2009), A Ideia de Justiça (SEN, 2013) e Desigualdade Reexaminada (SEN, 2012), o autor apresenta suas contribuições sobre a ideia de desenvolvimento, relacionada com a liberdade e a promoção de acessos a funcionamentos úteis, adequados a avaliações transitivas de necessidades para o igual exercício das capacidades pelas pessoas. A escolha do marco teórico justifica-se por tratar da temática de direitos humanos associada ao desenvolvimento e à promoção de políticas públicas, e também pelo fato de Amartya Sen ser nominalmente citado no Eixo Desenvolvimento e Direitos Humanos do PNDH-3, o que parece ter servido de inspiração às ações ali previstas.

Algumas considerações de fundo metodológico, que orientaram a condução desta pesquisa, são importantes para a melhor compreensão do leitor. Como se trata de investigação de natureza descritiva e teórico-analítica, nossa principal intenção é observar um conjunto de dados, analisá-los e interpretá-los, além de relacioná-los com a bibliografia escolhida, a fim de descrever um aspecto determinado da realidade. Portanto, o ponto de partida da investigação é conceitual, e visou, na exploração bibliográfica, compreender o significado do conceito de neodesenvolvimentismo.

Alguns dados auxiliam a compreensão da permanência de convenções de política econômica, como aqueles referentes ao crescimento econômico brasileiro nas décadas de 1990 e 2000. Tais dados corroboram a continuidade de um modelo de crescimento econômico com baixo dinamismo e instável. Outro aspecto conceitual imprescindível para a investigação 

investigação bibliográfica, e que buscou identificar os conceitos-chave para a teoria de Amartya Sen, de desenvolvimento como liberdade. Por fim, para a análise da agenda do direito ao desenvolvimento prevista no PNDH-3, partiu-se da interpretação documental, do texto propriamente dito das ações do programa, de alguns dados quantitativos disponíveis sobre o Governo Lula, úteis para contextualizar a formulação do Programa, e também de entrevistas com gestores responsáveis pela sistematização e redação das propostas contidas no texto.

Sob esse último aspecto, a pesquisa é parcialmente empírica; isto é, ela leva em consideração alguns dados da realidade, por nós coletados, para a obtenção de seus resultados, apesar de tais dados não constituírem as fontes fundamentais da própria investigação, mas de pontos de apoio para observação e interpretação. Nos dizeres de Lee Epstein e Gary King:

\begin{abstract}
A palavra @́mpíricoôdenota evidência sobre o mundo baseada em observação ou experiência. Essa evidência pode ser numérica (quantitativa) ou não-numérica (qualitativa); nenhuma é mais ñempíricaò que a outra. O que faz uma pesquisa ser empírica é que seja baseada em observações do mundo ï em outras palavras, dados, o que é apenas um termo para designar fatos sobre o mundo. Esses fatos podem ser históricos ou contemporâneos, ou baseados em legislação ou jurisprudência, ou ser o resultado de entrevistas ou pesquisas, ou os resultados de pesquisas auxiliares arquivísticas ou de coletas de dados primários. Os dados podem ser precisos ou vagos, relativamente certos ou muito incertos, diretamente observados ou conseguidos indiretamente; podem ser antropológicos, interpretativos, sociológicos, econômicos, jurídicos, políticos, biológicos, físicos ou naturais. Desde que os fatos estejam de alguma maneira relacionados ao mundo, eles são dados, e, contanto que a pesquisa envolva dados que são observados ou desejados, ela é empírica (EPSTEIN et. KING, 2013, p. 9-10)
\end{abstract}

Portanto, para alcançar os objetivos pretendidos, o caminho escolhido foi o de interpretação da realidade a partir de ampla investigação bibliográfico-conceitual, de alguns dados disponíveis sobre o governo Lula e sobre a economia brasileira, de dados documentais e também de dados empíricos, estes últimos decorrentes de entrevistas realizadas pelo autor. Ao final do trabalho, está anexado o roteiro que orientou as entrevistas realizadas, de caráter semi-estruturado.

Quanto à estrutura do texto da dissertação, o primeiro Capítulo apresenta uma breve trajetória da modernização capitalista brasileira, a fim de compreender a importância do desenvolvimentismo de matriz estruturalista e do neoliberalismo para a política econômica, e relacionar tais trajetórias como experiências constitutivas da concepção neodesenvolvimentista recente. Para tanto, também é utilizada a perspectiva de dependência de trajetória, ferramenta conceitual que auxilia a compreensão do quadro de escolhas políticas 
neodesenvolvimentismo.

O segundo capítulo, por sua vez, aborda o conceito de desenvolvimento, sob a perspectiva de ideia-força das economias globalizadas no capitalismo, e enquanto direito humano. Para tanto, resgatamos sua afirmação conceitual, a partir das anotações de Amartya Sen e, em seguida, apresentamos brevemente o contexto de seu reconhecimento no plano internacional.

Já o terceiro capítulo pretende analisar o conjunto de ações do Eixo Desenvolvimento e Direitos Humanos do PNDH-3, reportando-se à teoria de Amartya Sen e ao próprio conceito de neodesenvolvimentismo apresentados nos capítulos anteriores, e restringindo-se às discussões envolvidas no processo de formulação da política pública, e ao resultado concreto dessas discussões, traduzido no texto propriamente dito do Programa.

$\mathrm{Na}$ parte final do trabalho, apresentamos as considerações e conclusões da pesquisa, que corroboram a hipótese de adequação da agenda do direito ao desenvolvimento à política neodesenvolvimentista. Esperamos com isto poder contribuir para a compreensão das diferentes expressões do projeto de desenvolvimento e da agenda de desenvolvimento como direito humano em curso no Brasil, e apontar os principais desafios para sua realização. 


\section{ENTRE DESENVOLVIMENTISMO, NEOLIBERALISMO E NEODESENVOLVIMENTISMO: A FINA TRAMA DO DESENVOLVIMENTO BRASILEIRO}

\subsection{Introdução. Origem e breve conceituação}

Desde o ano de 2003, o termo novo desenvolvimentismo tem sido trabalhado pela literatura acadêmica, numa reflexão propositiva sobre os projetos de desenvolvimento para o Brasil. O termo aparece de forma conceituada e crítica pela primeira vez na obra de Luís Carlos Bresser-Pereira, autor conhecido por sua participação nos quadros da Administração Pública Federal, como Ministro de Estado da Fazenda, Ministro da Administração Federal e ainda Ministro da Reforma do Estado, nos governos de José Sarney e de Fernando Henrique Cardoso. Bresser-Pereira cunha o conceito pela primeira vez na 5a. Edição de Desenvolvimento e Crise no Brasil: História, Economia e Política de Getúlio Vargas a Lula (BRESSER-PEREIRA, 2003), ao introduzir um inédito capítulo 20, abordando de forma precisa e inaugural o conceito do que passou a ser definido como novo desenvolvimentismo:

(é ) um novo desenvolvimentismo, ou seja, uma teoria econômica e uma proposta de política econômica voltada para o desenvolvimento econômico. Uma proposta que não sofra dos vícios da frouxidão fiscal (populismo fiscal) e da frouxidão cambial (populismo cambial), mas que afirme a necessidade de uma intervenção firme do Estado para sanar parcialmente as falhas do mercado. Uma proposta que esteja comprometida com o equilíbrio fiscal e o fortalecimento do Estado, inclusive porque só Estados fortes podem garantir mercados fortes. Uma proposta que esteja voltada para os interesses dos mais pobres e para o interesse nacional. (...) O novo nacionalismo e o novo desenvolvimentismo admitem a superioridade econômica e tecnológica dos países desenvolvidos, mas não a sobreestima. Admite que eles tenham instituições melhores do que as nossas, mas não as copia servilmente, inclusive porque entre eles os modelos variam. (BRESSER-PEREIRA, 2003, pp. 430-445)

Não por acaso, o esforço teórico da geração que seguiu a reflexão de Bresser-Pereira, com o intuito de construir um novo conceito de política econômica para o país, aparece após a eleição de Luiz Inácio Lula da Silva à Presidência da República no ano de 2002, e se propaga nos anos seguintes, imbuída de força conceitual e crítica. Autores como Boito Jr. (2003) (2009), Sicsú et. al. (2005), Paulani (2008), Erber (2011), são expoentes, cada um a seu estilo, de reflexões sobre o modelo de sociedade, política e economia que seriam inaugurados nos anos da era Lula (2003-2010).

Sicsú (2005), a propósito, desenha em linhas gerais a origem do novo desenvolvimentismo na economia keynesiana, por haver certa relação complementar entre 
lismo cepalino, de que a industrialização não conseguiu resolver a forte desigualdade social, advogando uma transformação produtiva com maior equidade social. Isso permitiria compatibilizar crescimento econômico sustentável com melhor distribuição de renda. Apesar de reconhecer as diferentes nuances desse projeto, Sicsú ressalta a importância dessas características como um programa alternativo ao monetarismo neoliberal.

Este capítulo propõe discutir em que medida o conceito de neodesenvolvimentismo, tributário dessa matriz teórica novo-desenvolvimentista, representa uma nova realidade da economia brasileira: se de fato constitui uma ruptura ou transformação da linha de política econômica adotada pela administração petista pós-Cardoso, ou se consiste em leves ajustes conjunturais, em um cenário ainda marcado pela forte injunção internacional da liberalização dos mercados nacionais pós-Consenso de Washington. Para essa abordagem, a política econômica é considerada como política pública, e sua compreensão parte de uma análise baseada na noção de path dependence, ou dependência de trajetória, que busca entender como tal opção de desenvolvimento foi se constituindo, fortalecendo e alcançando as raias de um modelo econômico adotado recentemente por governos brasileiros, sem descuidar dos contextos passados que a informaram.

A reflexão econômica é, por excelência, a reflexão sobre os rumos dos modelos de organização produtiva de uma sociedade. Ela requer um aprofundamento sobre a realidade, percebida de forma imediata em suas evidências palpáveis, concretas, materiais. Trata-se de discutir como, por que e em que medida escolhas são adotadas para organizar a produção e circulação de bens, serviços e ativos numa economia. Isso abre também um importante leque de discussão sobre valores sociais, papel do Estado e das forças políticas representativas numa determinada sociedade, e sobre comportamentos e práticas sociais vigentes nessa mesma sociedade. Em última análise, a discussão sobre política econômica é uma discussão complexa, interdisciplinar, que envolve temas políticos, sociológicos, filosóficos, culturais e evidentemente, econômicos. Conforme aponta Souza (2011, p. 53):

No mundo moderno ï o mundo do naturalismo e da evidência material e concreta superficial como medida de todas as coisas $\ddot{i}$ tenderíamos a não perceber a influência de ideias. Isso é especialmente verdade num país como o Brasil, onde o mundo econômico, o mundo da materialidade por excelência, parece ser o único existente e visível. As concepções dos intelectuais, no entanto (é ) são centrais para a forma como uma sociedade escolhe e leva a cabo a seus projetos coletivos, (é ) são elas que explicam por que o mundo material e econômico visível e palpável se construiu dessa forma e não de outra forma qualquer, (é ) e explicam por que temos 'essa vida' social e política, e não qualquer outra possível. 
fundamentam escolhas e operam sobre essa realidade, criticar a adoção de escolhas políticas, entender certa gênese de problemas de fundo conjuntural e estrutural parece ser o desafio dessa geração de economistas e cientistas sociais e políticos, que começam a debater as transformações da economia brasileira no início do século XXI. Eles reinserem na evidência da realidade material e econômica, na superfície das aparências, a profundidade da análise crítica, e o papel das ideias não apenas como explicativas dessa realidade, mas também como transformadoras dela mesma. O papel das ideias que informam o projeto de política econômica (e o projeto político de país a ele subjacente), e explicam os porquês de nossa realidade material se constituir de uma forma e não de outra, é objeto dessa reflexão.

Esses autores se inserem em um período de novo vigor intelectual, preocupados com a uma formulação também assumidamente nova, que propunha se contrapor aos anos dos governos de Fernando Henrique Cardoso. Como veremos adiante, tais anos, compreendidos entre 1994 e 2002, foram profundamente marcados pela liberalização econômica do país e pela adoção, em maior ou menor medida, das regras basilares do Consenso de Washington ${ }^{1}$.

Escolhemos desbravar a discussão com o propósito de entender por que caminhos o Brasil trilha sua jornada rumo ao desenvolvimento, essa exigente e vacilante proposta da modernidade capitalista. Afinal, em que modelo de política o Brasil se afirma na condição de país em desenvolvimento, e em que medida isso consiste em uma novidade no cenário das políticas econômicas? Ela efetivamente se contrapõe à política econômica em curso nos anos da administração peessedebista?

A formulação do conceito de novo desenvolvimentismo, nesse sentido, parece tentar apontar uma saída aos dilemas que o capitalismo mundial, também em transformação, coloca(va)m à frente da inserção do Brasil no chamado sistema-mundo ${ }^{2}$ : o mundo que viu o

1 O Consenso de Washington foi o resultado de uma deliberação de funcionários do governo estadunidense com representantes de organismos financeiros ï Fundo Monetário Internacional, Banco Mundial e Banco Interamericano de Desenvolvimento, que resultou em propostas de políticas econômicas. Resultou do debate e avaliação de reformas econômicas empreendidas por países da América Latina no final dos anos oitenta. O encontro realizado em 1989 na capital dos Estados Unidos ganhou força simbólica nos foros internacionais multilaterais, integrando ideias esparsas e discursos isolados, sistematizando o que ficaria conhecido como ideário neoliberal: reformas profundas em prol da liberalização econômica e sobretudo financeira, desregulamentação, diminuição do papel do Estado em promoção de políticas sociais e distributivas. Trata-se de uma reformulação dos conceitos do liberalismo econômico clássico, que elege o mercado como a instituição social mais eficaz e que por isso deveria funcionar de modo puro, sem barreiras, considerando imprescindível diminuir ou mesmo aniquilar o papel das demais instituições sociais que despurifiquem a lógica fundamental de funcionamento do mercado: Estado, sindicatos, associações, cooperativas.

2 A teoria do sistema-mundo foi elaborada pelo sociólogo Immanuel Wallerstein, em sua obra The Modern World System, de 1974. Influenciado por uma perspectiva braudeliana de história, em que aponta a existência de uma estrutura mundial dividida entre centro, semiperiferia e periferia, Wallerstein descreve a existência 
socialismo real, é o mundo que, na década de noventa, viveu um período de intenso fortalecimento e hegemonização do capitalismo financeiro, avolumado pela expansão monetária, pelo crescimento de economias centrais e periféricas, e pela crescente liberalização de mercados. Em meio a esse crescimento, crises sucessivas nos finais do século XX começavam a dar sinais de alerta a essa liberalização financeira ascendente: México, Rússia, Argentina e Tigres Asiáticos foram acertados em cheio por bolhas especulativas ${ }^{3}$.

$\mathrm{Na}$ tentativa de contornar os dilemas estruturais do capitalismo financeiro e do receituário neoliberal mainstream que o acompanhou na década de noventa, o novo desenvolvimentismo se propõe não apenas como alternativa ao neoliberalismo, mas também ao desenvolvimentismo tradicional, de matriz estruturalista, que caracterizou o modo de desenvolvimento do capitalismo brasileiro em meados do século passado, marcado por forte intervenção do Estado em certos domínios econômicos. Essa intervenção buscava garantir preços, monopólios de produção de certos bens, sem descuidar de investimentos ï por meio de capitais nacionais ou estrangeiros $і ̈$ voltados ao crescimento econômico.

Entretanto, o que de fato se tem verificado, na tentativa de implementação do projeto novo desenvolvimentista brasileiro, é uma relativização prática, adaptada às exigências contextuais, que exigem medidas adequadas a expectativas de agentes de mercados, empresariado e que ao mesmo tempo responda a demandas sociais historicamente menosprezadas por políticas de governo.

interligada de duas esferas nessa estrutura: o sistema-mundo capitalista, acompanhada da divisão internacional do trabalho e o sistema-mundo interestatal, moldado a partir da tendência à guerra entre as nações modernas. Utilizamos essa noção de sistema-mundo para designar a aceleração do processo de globalização deflagrado com o fim da guerra fria, sobretudo a expansão hegemônica da lógica organizacional do sistema-mundo capitalista que, salvo raras exceções, atingiu em cheio a maior parte das nações do globo terrestre. (WALLERSTEIN, 2002, p. 45)

3 A crise mexicana data do biênio 1994-1995, e remonta a uma política macroeconômica de desvalorização cambial progressiva, coerente com as taxas de juros e com a inflação. Uma valorização cumulativa do peso mexicano e a abertura do país ao Nafta fez aumentarem as importações e gerou um forte desequilíbrio no balanço de pagamentos mexicanos, o que empurrou o país à desregulamentação da entrada de capitais financeiros, a fim de criar reservas que equacionassem esse desequilíbrio. Já a crise dos Tigres Asiáticos teve início em 1997, num processo de fuga de capitais e deflação de ativos financeiros, em que as moedas nacionais de alguns países (Tailândia, Malásia, Indonésia e Filipinas) sofreram forte desvalorização cambial, acompanhadas da recessão econômica japonesa e do declínio de exportações da Coreia do Sul, tratando-se uma crise das finanças desreguladas e globais. A crise russa, por sua vez, ocorrida em 1998, que levou o país a decretar sua moratório, foi resultado do impacto da crise dos Tigres Asiáticos, em razão da redução da liquidez internacional, reduzindo o crédito ao país e a queda no preço das commodities exportadas pela Rússia. A crise argentina, de 1999, foi marcada pelo fim do regime cambial de paridade entre o peso argentino e o dólar, um medo generalizado da desvalorização da moeda local de forma expressiva, e, diante da desvalorização do real em 1999, uma expressiva redução de suas exportações, o que desequilibrou sua balança de pagamentos e levou o país a decretar da moratória da dívida externa em 2001. Neste sentido, ver a obra de José Luís Fiori: 60 lições dos 90. (FIORI, 2002) 
híbrida de sua matriz teórica, que intenta conciliar as formas de capitalismo vividas pelo país nas últimas décadas, oscilando entre a intervenção do Estado na esfera econômica e as regras e pressupostos de funcionamento dos mercados tidos por livres, através da redução de custos transacionais e proteção integral à propriedade privada. Tal espécie foi recentemente batizada de neodesenvolvimentismo.

Esse termo passou a expressar algo que estaria numa posição intermediária, entre uma revisão dos anos de política neoliberal, e a proposta assumida pelo novo desenvolvimentismo. A diferença entre novo desenvolvimentismo e neodesenvolvimentismo, dois termos que expressariam motes distintos da política econômica, estaria no fato de o primeiro modelo ser caracterizado como uma formulação de natureza mais teórica, referindo-se a um conjunto de exigências e propostas para a estratégia nacional de desenvolvimento de países de renda média, na contramão das exigências neoliberais, enquanto o segundo, a política econômica brasileira efetiva, real, experimentada nos últimos anos pelas administrações petistas de Luiz Inácio Lula da Silva (2003-2010). Essa diferença é explicitada com maior clareza por Fábio Erber, que aponta:

\begin{abstract}
Do ponto de vista econômico, seu núcleo duro [o do neodesenvolvimentismo] é de inspiração keynesiana $\delta$ o crescimento é impulsionado pelo aumento autônomo da renda familiar dos grupos mais "pobres", via salário mínimo e transferências fiscais, e de investimentos em infraestrutura e construção residencial, regidos pelo Estado. No entanto, distingue-se da convenção "novo-desenvolvimentista", que tem a mesma matriz teórica (...), pela aceitação, mesmo que a contragosto, da política macroeconômica da convenção institucionalista restrita, que os "novodesenvolvimentistas" explicita e fortemente rejeitam. (ERBER, 2011, p. 8)
\end{abstract}

Para Erber, o conceito de novo desenvolvimentismo constitui-se muito mais num apelo crítico de economistas e acadêmicos em disputa pela hegemonia de um projeto de desenvolvimento para o Brasil que, de fato, um conjunto sistemático de políticas e medidas implementadas pelos governos petistas recentes. Sua principal crítica volta-se à existência de um modelo híbrido de desenvolvimento, designado como neodesenvolvimentista. Esse modelo representaria uma convenção que, por um lado, preserva os pressupostos fundamentais da convenção institucionalista ${ }^{4}$, e, por outro, adota uma maior participação do

4 Ao utilizarmos o termo ñconvenção institucionalistaò, referimo-nos a uma corrente de pensamento centrada na noção de evolução gradual da economia, focada no papel das instituições sociais nesse processo. Hábitos, aprendizado sujeitos, crenças e ações dos indivíduos caracterizariam a busca por produtividade e a lucratividade, e estariam dependentes de uma trajetória precedente historicamente construída, ao longo desse processo evolutivo. Sâo expoentes dessa corrente Thorstein Veblen, Adolph Berle e Clarence Ayres. Apesar de diretamente não se referir a uma convenção neoliberal, veremos adiante haver uma aproriação dessa perspectiva, do ponto de vista ortodoxo, que admite o funcionamento da economia somente se preservados alguns pressupostos fundamentais $\ddot{i}$ tornados instituições $\ddot{i}$ e definidos pela atuação do Estado. Essa 
infraestrutura, expansão de crédito público e privado, criação de círculo virtuoso estimulado pelo consumo e aumento de renda, investimento em inovação e de uma política externa independente. (ERBER, 2011) Para o autor, essa convenção é também marcada por uma visão competitiva e meritocrática da economia, para a qual algumas normas e organizações garantem o funcionamento correto dos mercados, vinculando-se a uma visão institucionalista ortodoxa: metas fiscais e de inflação, e autonomia e protagonismo no Banco Central para a definição de políticas de juros seriam características marcantes dessa visão.

Trabalharemos com maior detalhamento, mais adiante, com os reais sentidos do neodesenvolvimentismo, e avaliaremos que medidas, ações e decisões constituem sua agenda formativa. Por ora, aderimos à percepção de Erber: o neodesenvolvimentismo germina, floresce e se explica num contexto de realpolitik ${ }^{5}$ capitalista, e se afirma reproduzindo ou reforçando instituições típicas desse contexto: crença na eficácia e legitimidade do livre mercado (isto é, o mercado enquanto instrumento mais legítimo e eficaz de organizar e conduzir a economia e a sociedade) na alocação de recursos, adoção de instrumentos e de políticas estatais ï como as metas de inflação via definição da taxa de juros de títulos da dívida pública por uma autoridade monetária, o Banco Central, estabilização de preços relativos, adoção de um superávit primário por meio de rigor fiscal, e flutuação cambial e valorização das taxas de câmbio.

Esse conjunto de medidas tem como intenção clara atender os interesses de agentes financistas e setores empresariais, intimamente relacionados com a estrutura do Estado por meio de vínculos não tradicionais (isto é, em alguma medida informais, constituídos nos bastidores da política). Foi o que o sociólogo e ex-presidente da República, Fernando Henrique Cardoso, definiu como anéis burocráticos. ${ }^{6}$ Abordaremos com mais atenção essas

dependência de instituições acaba por fazer o neodesenvolvimentismo herdar um arcabouço institucional neoliberal e, se no plano discursivo prefere se esquivar dessa imputação, objetivamente guarda importantes semelhanças com ele.

5 O termo realpolitik é uma palavra em alemão que literalmente traduzida significa ñpolítica realò. Foi usada pela primeira vez por Ludwig von Rochau, escritor e político alemão do século XIX para designar a concepção de Meternich, no plano das relações internacionais, para o equilíbrio de forças entre as principais nações imperialistas europeias após o Congresso de Viena (ROCHAU: 1853). O autor descreve o termo em Grundsätze der Realpolitik angewendet auf die staatlichen Zustände Deutschlands, de 1853, como o estudo dos poderes que modelam, mantêm e alteram o Estado e a base de todo o discernimento político, e leva à compreensão que a lei do poder governa o mundo das nações da mesma maneira como a lei da gravidade governa o mundo físico. Desta forma, o termo passou a se referir, de modo geral, à política real, mais ao realismo e pragmatismo político e menos à ideologia política, com os constrangimentos das forças organizadas, das alianças e correlações pragmáticas, e dos modos de fazer política limitado pelos contextos históricos e fatores domésticos e externos.

6 O termo anéis burocráticos foi cunhado pela primeira vez por Fernando Henrique Cardoso para analisar a 
uma espécie híbrida, que bebe tanto na fonte novo-desenvolvimentista, quanto bebe, seja a contragosto ou em benefício de interesses reais do jogo político, o amargo xarope do receituário neoliberal do Consenso de Washington. O termo neodesenvolvimentista, assim, é o mais adequado para a crítica, pois reflete a preocupação com o que de fato tem cada vez mais se constituído enquanto modelo econômico. E é esse modelo o que ocupa especial atenção deste trabalho.

\subsection{Historicizando o neodesenvolvimentismo. Notas e inflexões políticas.}

O neodesenvolvimentismo, como apontado, é um sistema híbrido ï que adota características da convenção novo-desenvolvimentista e da convenção neoliberal ï e um sistema em construção, posto que experimentado recentemente pelos governos petistas, em um certo processo de transformação conjuntural no Brasil contemporâneo. Portanto, sua notícia histórica é imprescindível para que entendamos sua ascensão, suas características, o que de fato herdou como espólio do desenvolvimento capitalista brasileiro, e as principais razões de sua implementação.

Ao adotar uma perspectiva que relaciona intimamente o desenvolvimento do país com o desenvolvimento econômico, o neodesenvolvimentismo concebe a dinamização e diversificação das atividades econômicas como fortes aliadas a uma segunda transformação, de caráter social, isto é, através da diminuição, ainda que superficial, de profundas desigualdades e barreiras historicamente constituídas.

Para a análise do atual estágio da política econômica brasileira, escolhemos apresentar uma brevíssima resenha do processo de modernização econômica no Brasil, uma vez que as condições econômicas do presente são informadas por um passado, que alicerçou as bases fundamentais do capitalismo e da disputa de projetos políticos ao seu redor.

Nesse passado, a industrialização, se poderia contribuir a um salto do desenvolvimento do país $̈$ i segundo as visões predominantes em diferentes épocas $\ddot{i}$ jamais conseguiu saldar a dívida histórica da colonização e não foi capaz de promover profundas e radicais transformações das imensas desigualdades na sociedade brasileira. O Brasil, no século XX,

organização política da sociedade brasileira com relação ao Estado planejador e desenvolvimentista. O conceito serve para designar as ligações entre a burocracia estatal, (seja do governo ou de suas empresas públicas) com a burocracia corporativa do setor privado: empresas, sindicatos, agências nacionais e internacionais. Essas ligações extrapolariam as diretrizes do próprio Estado. (CARDOSO, 1972) 
homia mundial, e apresentou nesse mesmo período as maiores taxas de crescimento econômico acumulado do mundo. Os processos de modernização capitalista e industrialização brasileiros revelaram-se, contudo, extremamente concentradores, desafiando a visão economicista-liberal, de que o simples crescimento econômico geraria maiores oportunidades e diminuiria drasticamente os abismos sociais entre ricos e pobres, ou, noutros termos, de que a industrialização seria a via de superação da pobreza em uma determinada sociedade.

O neodesenvolvimentismo, herdeiro do processo de modernização capitalista do Brasil, propõe uma aliança que tenta conciliar crescimento econômico e distribuição de renda e, se em certa medida repete o passado, em outro plano tenta romper com ele, num contexto distinto e repleto de desafios, como é o de globalização econômica. Consideramos importante revisitar, ainda que brevemente, esse passado, para compreendermos de que forma a proposta neodesenvolvimentista se revela no presente.

Abordamos a seguir de forma bastante breve e sem maiores detalhes, apenas para situar o leitor, o primeiro e segundo ciclos de formação do desenvolvimentismo brasileiro, que oferecem elementos para a constituição da proposta novo desenvolvimentista, cientes dos riscos de pequeno aprofundamento que os objetivos deste trabalho nos cerceia. Exploramos as transformações recentes do capitalismo no Brasil no final do século XX, com a escalada do neoliberalismo, seguido pelo embate entre projetos distintos de país na arena política, e a constituição do que poderíamos chamar de opção neodesenvolvimentista, no curso desenhado pelas transformações do capitalismo no Brasil.

\subsubsection{0-1964: o primeiro ciclo do desenvolvimentismo brasileiro}

De início, cabe observar que a economia brasileira ingressa na modernidade capitalista precisamente a partir de 1930. A r̃Revoluçãoò iniciada naquele ano representou um golpe certeiro no projeto de país dominado por um sistema político de alianças locais e regionais nacionalmente projetadas, e um golpe também no modelo econômico de matriz agrárioexportadora, altamente dependente da demanda internacional. Por isso, sujeito a variações cambiais e flutuações de estoque de bens primários, como o café, a borracha, o açúcar e outros. Apoiada por diferentes setores das elites brasileiras, de constitucionalistas liberais a lideranças tenentistas semiautoritárias e nacionalistas, cúpula das forças armadas a 
desvalorização da atividade, a ñRevolução de 1930ò foi responsável por profundas mudanças na economia brasileira (SKIDMORE, 2010).

1930 não apenas inaugura o ingresso do Brasil na modernização capitalista, por meio de uma acelerada industrialização, através do Modelo de Substituição de Importações - MSI, mas também dá o pontapé inicial a um projeto de desenvolvimento nacionalista, uma vez que a industrialização foi fortemente incentivada e promovida pelas mãos do Estado, e estava voltada ao aumento de demanda interna e estímulo ao fortalecimento de mercado. Esse processo de industrialização é caracterizado pelo etapismo, que, em fases sequenciais de diversificação produtiva, aos poucos dinamiza a produção industrial, partindo da produção de bens de consumo não duráveis, seguindo para os bens de consumo duráveis, prosseguindo aos bens intermediários até que sejam produzidos bens de capital.

O que se inaugura com o governo de Getúlio Vargas, a partir de 1930, é uma forte participação do Estado no domínio econômico, que se justifica pela necessidade de recuperar o atraso histórico da economia brasileira, tornando-a dinâmica, expandindo seu mercado interno e criando condições estruturais para investimento e poupança. Essa forma estatal de intervenção na economia mudaria aos sabores das intenções políticas, e formaria os ciclos ideológicos e estruturantes do que a literatura resolveu chamar de desenvolvimentismo: ñm projeto de industrialização integral como via de superação do subdesenvolvimento, conduzido pelo Estadoò. (BIELSCHOWSKY, 2010, p. 15). Conforme aponta Celso Furtado, a crise de 1929 faz, portanto, o ñcentro dinâmico da economia brasileira se deslocar do mercado exterior para o mercado internoò. (FURTADO, 2007, p. 278). E, ainda mais, a crise de 1929, que resultou na chamada Revolução de 1930, não só desloca o centro dinâmico do mercado externo para o interno, como também inicia com maior vigor o processo de deslocamento do centro dinâmico da economia brasileira: do campo para a cidade.

A maior participação do Estado na vida econômica do país ï que desenha as formas principais do desenvolvimentismo que se organizou no Brasil ï a partir de 1930, é verificada através de seu desempenho em quatro funções principais: a adequação de um arcabouço legalinstitucional à indústria, com a adoção de uma legislação trabalhista reguladora do mercado de trabalho urbano em expansão, e de uma burocracia estatal e de agências para gestão do processo de desenvolvimento ( $\mathrm{DASP}^{7}, \mathrm{BNDE}^{8}, \mathrm{CTEF}^{9}$, etc.). Além disso, a criação de uma

7 O Departamento Administrativo do Serviço Público foi um órgão criado pelo Decreto-lei $n^{\circ} 579$, de 30 de julho de 1938, portanto, posteriormente à Constituição de 1937, que inaugura o Estado-Novo varguista e tinha como objetivos organizar e a racionalizar o serviço público no país, e proceder a uma ampla reforma 
produção, o fornecimento de insumos básicos necessários ao processo de industrialização, com a criação de empresas estatais que oferecessem aço, minério e petróleo, por exemplo, à demanda crescente do parque industrial nascente (Companhia Siderúrgica Nacional, Companhia Vale do Rio Doce e Petrobrás), e o financiamento da economia, por meio de bancos públicos, como o Banco do Brasil e o Banco Nacional do Desenvolvimento Econômico - BNDE (GREMAUD et. al., 2011). Curiosamente, apesar de temporalmente localizadas, essas formas de atuação não são menos frequentes em tempos mais recentes, em que o papel da legislação ainda é importante para ñdestravarò investimentos e regular setores da economia, os investimentos públicos em sistemas de concessões para obras de infraestrutura são exigidos por setores produtivos ao governo, o papel da Petrobrás na intervenção de estoques e controle de preços do mercado interno de combustíveis ainda é visível, e mesmo Caixa Econômica Federal, Banco do Brasil e BNDES constituem importantes fontes de financiamento de atividades produtivas, como a pequena agricultura familiar, a habitação ou a expansão comercial de empresas. Em suma, as medidas iniciadas com Vargas, que inauguravam a nova fase da economia brasileira, voltada ao centro dinâmico de seu mercado interno, constituem marcos da própria ação organizadora do Estado, enquanto força motriz da formação do capitalismo industrial no Brasil, influenciando ações governamentais também de anos mais tarde.

A participação do Estado na economia fica clara também nos anos que se seguiram a Vargas. Sucessivas intervenções, que oscilavam entre um caráter mais ortodoxo e certa heterodoxia da equação Estado-mercado, apontavam os rumos conjunturais do processo de modernização brasileiro. O rigor no controle inflacionário e nos preceitos liberais propagados

administrativa do Estado.

8 O BNDE, inicialmente Banco Nacional de Desenvolvimento Econômico, foi criado pela Lei $\mathrm{n}^{\mathrm{o}} 1.628$, de 20 de junho de 1952, como uma autarquia federal vinculada ao Ministério da Fazenda, no governo de Getúlio Vargas pós-Estado Novo, em seu mandato eleito iniciado em 1951. Em 1971 a autarquia tornou-se empresa pública, ampliando sua capacidade de captação e aplicação de recursos, desempenhando um papel fundamental no processo de substituição de importações, e canalizando seus investimentos em setores de bens de capital e insumos básicos. O Banco passou a ser designado Banco Nacional de Desenvolvimento Econômico e Social em 1982, por meio do Decreto no 1.940, de 25 de maio. Sua trajetória institucional revela as disputas dos modelos econômicos brasileiros, desde sua criação. O Banco foi responsável pela operacionalização técnica do processo de privatizações iniciado em 1991, com o Plano Nacional de Desestatização. Passou a vincular-se ao Ministério do Desenvolvimento, Indústria e Comércio Exterior. Sua principal função é fomentar as atividades produtivas do país, por meio da captação de recursos e oferta de crédito a preços baixos a diferentes setores da economia, com incentivo às exportações, o fortalecimento do mercado de capitais e a promoção da competitividade da economia brasileira.

9 O Conselho Técnico de Economia e Finanças foi um órgão técnico consultivo do Ministério da Fazenda, criado em 1937, com o objetivo de reunir informações sobre a tributação, situação financeira e outras informações, como legislação bancária e monetária, incentivos fiscais e política energética, das diferentes unidades da federação, no processo de centralização administrativa promovido no Estado-Novo varguista. 
governo combinou, em seu começo, taxa de câmbio sobrevalorizada, controle de importações e contrações no investimento público, com expansão creditícia e maior frouxidão monetária, em seu final, para citarmos um exemplo.

Merece destaque também, na formação econômica de tom desenvolvimentista, o governo de Juscelino Kubitscheck (1956 ï 1961), que lançou o Plano de Metas. Tal plano foi concebido sob a forma pragmática de uma economia mista, pois visava o crescimento tanto do setor público quanto do setor privado, em um mote de extremo otimismo, progressista, de produzir um verdadeiro salto da economia brasileira: cinquenta anos em cinco. Tendo angariado apoio político de classes empresariais e de trabalhadores por meio de reajustes salariais, e promovido investimentos em infraestrutura $і$ com a mudança do eixo prioritário de transportes, do ferroviário para o rodoviário ï o Plano de Metas de Kubitscheck merece destaque no processo de industrialização brasileiro, por adotar uma política de maior endividamento externo, uma vez que admitiu investimentos estrangeiros sem cobertura cambial, e incentivou isenções fiscais que estimularam a instalação de empresas estrangeiras no país. (GREMAUD et. al., 2011). Tal período foi também marcado por forte crescimento econômico, aumento de inflação e concentração de renda, e profundas mudanças estruturais, com a expansão da atividade industrial em taxas de crescimento superiores a 10 porcento ao ano. (GREMAUD et. al., 2011).

Contudo, uma conta cara foi cobrada anos mais tarde. O MSI apresentava limites bastante claros: além de se caracterizar pela produção de forte concentração de renda, apresentava crescimento marginal de demandas por novos equipamentos e tecnologias, acompanhado de lucros cada vez menores resultantes do incremento produtivo: o mercado interno não crescia no mesmo ritmo das expectativas dos setores industriais. A inflação crescente preocupava setores empresariais, que viram também os estímulos estatais viabilizadores de investimentos serem sufocados ou inibidos no começo da década de sessenta, após o Plano de Metas. Sob tais condições, o populismo brasileiro ${ }^{11}$ que gravitava ao

10 Os Acordos de Bretton Woods designam disposições ajustadas por países aliados em julho de 1944, na cidade de Bretton-Woods, estado de New Hampshire, Estados Unidos. Essas tratativas tinham por objetivo estabelecer diretrizes para a economia mundial no pós-guerra. São precisamente esses acordos que fazem surgir um sistema financeiro de caráter mundial, beneficiando fortemente a economia estadunidense, ao adotar o dólar como moeda padrão para transações correntes. Os EUA assumiam assim um importante papel no sistema de distribuição de capitais na economia mundial.

11 Ao usarmos o termo populismo, referimo-nos à forte base de sustentação popular de governos chefiados por lideranças carismáticas, que promoveram medidas reformadoras e geralmente expansionistas da renda de trabalhadores, com importantes expoentes: Getúlio Vargas, Juscelino Kubitscheck e o próprio João Goulart são presidentes marcados por esse apoio popular. 
ista encontrava-se, na primeira metade da década de sessenta, em estágio terminal. Caracterizava-se pela elevada inflação, o alto endividamento externo e também pela limitação de remessas de lucros para o exterior ${ }^{12}$.

Esta crise encerrou o primeiro ciclo de formação do desenvolvimentismo brasileiro, que se caracterizou pela definição estatal da expansão de setores específicos da economia, pela captação de recursos no exterior, e pela promoção de investimentos estratégicos em áreas consideradas prioritárias, como a indústria de base $̈$ i siderúrgica, de extração e refino de petróleo, e mineração, por exemplo. Ficou também clara, nesse período, a dificuldade de formação de uma burguesia industrial autonomista, capaz de liderar o processo de industrialização, centrado fortemente no Estado.

A crise sinalizava um profundo nível de tensão que se colocava, relativa a interesses em disputa no processo de modernização brasileiro: de um lado, crescia a preocupação sobre como retomar o rápido crescimento econômico e destinar os benefícios desse crescimento a uma fatia cada vez maior da população brasileira, além de equilibrar industrialização e agricultura, as fontes de capital (estrangeiro, público e privado), a correção de desequilíbrios regionais e a distribuição de renda quanto a salários, tributos e políticas de bem-estar, além de como alcançar tais objetivos com uma inflação controlada (SKIDMORE, 2010). De outro lado, uma tensão cada vez maior de setores tradicionais e novos, sobre os passos que eram dados nessa direção, e um alarmismo generalizado sobre o conteúdo e natureza de reformas empreendidas nesse sentido.

Três assuntos figuravam-se como centrais na discussão da crise que o modelo apresentava: ñcomo sustentar a continuidade do processo de crescimento no Brasil; qual seria a exata participação do capital estrangeiro nesse processo; e de que forma a industrialização poderia reverter a miséria urbana em crescimentoò. (BIELSCHOWSKY, 2010, p. 19). O historiador brasilianista Thomas Skidmore (2010, pp. 360-365) apresenta um cenário bastante esclarecedor sobre esse período:

\footnotetext{
Nos vinte anos transcorridos desde o fim da Segunda Guerra Mundial, o Brasil se revezara entre a expansão e a tentativa de estabilização. Depois da exaustão das reservas de moeda estrangeira em 1947, o país incorrera num crescente endividamento externo. O financiamento estrangeiro era um resultado previsível e necessário do impulso de industrialização. Ainda assim, adiava uma parte do custo do desenvolvimento, e representava um fardo crescente, que se transformou em desvantagem política cada vez maior para sucessivos governos. A taxa de crescimento econômico continuou alta, uma das mais altas do mundo até 1962, mas o amplo uso de financiamento estrangeiro significava que uma percentagem cada vez
}

12 Por meio das reformas de base implementadas por João Goulart, em especial através do Decreto 53.451, de 20 de janeiro de 1964, que garantia à Superintendência de Moeda e de Crédito ï SUMOC o controle de todas as operações de remessa de lucros, evitando a evasão de divisas e o descontrole cambial. 

político (é ) atitude que (é ) era fomentada pela esquerda organizada, culpava a incompreensão e a má vontade estrangeiras pelas dificuldades do Brasil para manter o desenvolvimento econômico. Como acontecia com tantos países em desenvolvimento, uma mobilização total de recursos foi o que faltou claramente ao Brasil durante seu impulso desenvolvimentista da década de 1950. (é ) O fato é que a necessidade de escolhas impopulares e dolorosas em estratégia de política econômica impôs sérios limites ao potencial de liderança carismática ou populista (é ) [e] a incapacidade de controlar a elite política no meio de uma controvertidíssima crise de formulação econômica.

Uma conta cara foi cobrada à organização política brasileira, anos mais tarde, muito em razão das controvérsias da política econômica brasileira do período. Tal conta foi representada pelos anos de chumbo sucedâneos, e o período autoritário estendido até 1985, com a ditadura civil-militar. Para se ter uma ideia, no ano imediatamente antecedente ao golpe de 1964, a economia brasileira apresentou um crescimento muito pequeno, de apenas $0,6 \%$, e retração da produção industrial (GREMAUD, 2011), o que se mostrava completamente díspar aos anos precedentes. Os setores produtivos reagiam, vociferantes, às tentativas de reformas de base propostas por João Goulart, que pretendia constituir um trabalhismo progressista, através da ampliação de direitos sociais a trabalhadores do campo e da cidade. $\mathrm{O}$ abalo conjuntural significava crise para esses setores, e deveu-se, em grande medida, a uma insatisfação de lideranças de setores empresariais e à trajetória de contribuição do Estado no processo de modernização e crescimento econômico. Ou seja, se a economia apresentava sinais de instabilidade e debilidade, o que parecia também instável e débil, a esses setores, também era o Estado, ou o governo que o ocupava. Portanto, era necessária uma incisiva alteração da ordem institucional, segundo essa visão.

Num contexto de crise do populismo, tentativas de reformas de base por João Goulart, pressões externas apoiadas no discurso anticomunista e antiesquerdista da guerra fria e a instabilidade política e institucional interna, além de uma sensível adesão de parcelas da sociedade, como algumas classes médias urbanas, parte importante do empresariado brasileiro viu seus interesses contemplados pelo regime inaugurado com o Golpe Militar de 1964, tendo a ele oferecido seu apoio e financiamento, assim como à ditadura que com ele foi instaurada.

\subsubsection{O segundo ciclo de formação do desenvolvimentismo brasileiro: 1964-1980}

O Golpe de 1964 marca o início de um novo período da história econômica brasileira. Trata-se de um corte no desenvolvimentismo que vinha se apresentando até então, no qual o 
ões e crescimento econômico eram acompanhados de um forte endividamento externo e aumento inflacionário, e de um importante processo de urbanização. O regime autoritário instalado no país abraçou o processo desenvolvimentista em curso, mas o conduziu com diferenças importantes: o Estado criou estruturas institucionais nada desprezíveis de incentivo à concentração e formação de grupos empresariais em setores estratégicos, criou também uma estrutura cada vez mais complexa de burocracia empenhada em controlar a inflação, como lograram fazer os ministros de Estado do Planejamento, Roberto Campos, e da Fazenda, Octávio Gouvêa de Bulhões, ao criarem o Banco Central do Brasil e o Conselho Monetário Nacional (CMN), logo após o golpe de 64.

Não se alterou, contudo, o quadro de endividamento externo, pois por mais nacionalista que o regime fosse no plano econômico, a capacidade baixa de financiamento de grandes projetos dependia de empréstimos externos. No plano discursivo, o regime alicerçou seu fundamento na burotecnocracia ï quadros qualificados envolvidos com uma técnica para operar ñmilagresò e favorecer os setores considerados estratégicos, a fim de alavancar o crescimento da economia. E, o mais importante, prevalecia o argumento de crescimento econômico em primeiro lugar, para em sequência, se proceder à divisão de seus resultados: a efetiva distribuição de renda. Essa nova roupagem institucional revelava a disputa pelo controle da hegemonia das formas concretas que o desenvolvimento assumiria no país.

A disputa travada pelo controle hegemônico do Estado e do projeto de país que isso implicava foi capitaneada por setores empresariais que não buscavam romper com as bases fundamentais do desenvolvimentismo inaugurado na Era Vargas.

A ditadura civil-militar contribuiu para que o capitalismo monopolista brasileiro ganhasse enorme vigor, através de políticas estatais de amplo protecionismo, fazendo emergir grandes grupos empresariais em três setores-chave, conforme apontam Mantega e Moraes: o bancário e financeiro (com os grupos como o Moreira Salles, Bradesco e Itaú), o da indústria pesada (com os grupos empresariais Gerdau, Votorantim, Villares e outros) e o da construção civil (particularmente, com as quatro maiores empresas do setor, Camargo Corrêa, Andrade Gutierrez, Mendes Júnior e Odebrecht). (MANTEGA et. MORAES, 1991). O BNDE teve papel central na concessão de crédito a essas empresas, estimulando a concentração de capital em gigantes de setores específicos, que constituíram relações informais com o Estado, por meio de anéis burocráticos, isto é, ñpequenos grupos de empresários individuais conectados a burocratas de forma também individualizadaò. (EVANS, 2004, p. 98)

Os laços entre empresariado brasileiro e a ditadura foram constituídos de maneira muito menos institucionalizada e, se à primeira vista o regime iniciado em 64 engendraria um 
le favoreceria a constituição de tais laços, por outro, implicava também formas de favorecimento insulado, privilegiado e setorial da economia. Nesse sentido, discordamos da abordagem que Schneider (SCHNEIDER, 1994) apresenta, de que o êxito da política industrial brasileira no período teria relação direta com sua formulação tecnocrática legal-racional, como fizeram Roberto Campos e Mário Henrique Simonsen, em defesa de uma política econômica despolitizada, marcadamente técnica e por isso mesmo superior ao que havia se verificado até 1964. Essa forma de interpretação da política econômica é errônea, ao afirmar que a política seria algo externo à burocracia, quando na verdade o que acontece é precisamente a manifestação de escolhas contextualizadas, que avaliam estratégias distintas de atuação, e que constituem, nesse período, um fazer político de agentes estatais, entrelaçados com os setores produtivos.

O segundo ciclo desenvolvimentista, iniciado em 1964, estende-se deste modo até 1980, ainda marcado por uma forte intervenção e planejamento estatal na economia, com a finalidade de industrialização do país. $O$ período consolida um desenvolvimentismo autoritário, em que o Brasil alcançou o que se chamou de ñmilagre brasileiroò, apresentando expressivas taxas de crescimento, superiores a oito porcento ao ano, forte aceleração de investimentos, execução de grandes obras e projetos que beneficiaram setores específicos da economia (construtoras e bancos, p. ex.), controle de inflação e crescimento dos níveis de emprego e renda, considerados pelos governos militares como o caminho para a melhoria das condições de vida da população. A ideia-força que movia a política econômica era crescer a riqueza do país, ou ñfazer o bolo crescerò para então poder reparti-lo, nos termos usados por Antônio Delfim Netto, Ministro da Fazenda (1967-1974) e do Planejamento (1979-1985) no período da ditadura civil-militar.

O período difere-se do primeiro ciclo de formação do desenvolvimentismo brasileiro, na medida em que, além do mencionado nível de interação entre burotecnocracia e empresariado, fez surgirem divergências teóricas importantes, apresentadas por uma geração de economistas ${ }^{13}$, ao modelo autoritário. O modelo autoritário mostrava-se incapaz de equacionar os graves problemas sociais que vinham acompanhando a acelerada industrialização e urbanização do país, desassociada da distribuição de renda.

Até meados da década de setenta, esse modelo se consolida num cenário de extremo

13 Maria da Conceição Tavares, Celso Furtado, José Serra, Edmar Bacha, Antônio Carlos Lessa e outros são expoentes dessa crítica, que caracterizava a expansão do modelo militar como socialmente perversa, com trágicos saldos de concentração de renda e desigualdade social. (BIELSCHOWSKY, 2006, p. 47). 
com o segundo choque, em $1979^{15}$. As crises do petróleo representaram o momento mais delicado da internacionalização econômica brasileira: as vulnerabilidades externas ameaçavam o modelo de incentivos à economia nacional. Essa fase sinalizou, à economia do país, e ao próprio modelo desenvolvimentista em vigor, sua crise e decadência, anunciando também a queda livre da organização autoritária do Estado brasileiro, e uma nova lógica de projeto nacional.

Para uma breve comparação entre os dois primeiros ciclos de formação do desenvolvimentismo brasileiro, sugerimos observar a figura 1 abaixo:

Figura 1: Quadro comparativo dos aspectos gerais da economia brasileira entre os dois ciclos do desenvolvimentismo

\begin{tabular}{|c|c|c|}
\hline $\begin{array}{c}\text { Endividamento } \\
\text { externo }\end{array}$ & $\begin{array}{c}\text { Primeiro Ciclo do } \\
\text { Desenvolvimentismo (1930 - } \\
\text { 1964) }\end{array}$ & $\begin{array}{c}\text { Segundo Ciclo do Desenvolvimentismo } \\
\text { (1964-1985) }\end{array}$ \\
\hline $\begin{array}{c}\text { Controle } \\
\text { inflacionário }\end{array}$ & $\begin{array}{c}\text { Baixo, oscilando mais em } \\
\text { direção ao aumento das } \\
\text { taxas de inflação }\end{array}$ & $\begin{array}{c}\text { Alto, por meio do PAEG, Plano Trienal, } \\
\text { minidesvalorizações cambiais, inflação } \\
\text { reprimida no governo Geisel; correção } \\
\text { monetária até que a inflação atingisse } \\
\text { os 10 porcento ao ano }\end{array}$ \\
\hline $\begin{array}{c}\text { Taxas médias de } \\
\text { crescimento }\end{array}$ & $\begin{array}{c}\text { 5,6\% a.a. } \\
\text { 6,29\% a.a. }{ }^{16}\end{array}$ \\
\hline $\begin{array}{c}\text { Investimento em } \\
\text { setores da } \\
\text { economia }\end{array}$ & $\begin{array}{c}\text { Sobretudo bens } \\
\text { intermediários (aço, } \\
\text { petróleo, derivados) e bens } \\
\text { de produção (maquinário, } \\
\text { instalação de indústrias } \\
\text { automotivas, etc.) }\end{array}$ & $\begin{array}{c}\text { Bens de produção, bens de consumo, } \\
\text { insumos básicos, etc. }\end{array}$ \\
\hline Endividamento & \multicolumn{2}{|c|}{ Sim } \\
\hline
\end{tabular}

14 O primeiro choque do petróleo refere-se ao boicote internacional de fornecimento de petróleo pelos países produtores da Organização dos Países Exportadores de Petróleo ï OPEP, cartel formado sobretudo por nações do Oriente Médio de formação cultural islâmica. Tal boicote se deu em resposta ao apoio estadunidense à permanência do Estado de Israel ao longo da guerra do Yom Kippur, deflagrada em outubro de 1973, com o contra ataque de Síria e Egito contra o estado israelense.

15 O segundo choque do petróleo ocorreu com a deposição do Xá da Pérsia, Reza Palehvi em 1979, a ascensão da República Islâmica do Irã com o movimento revolucionário e o conflito desencadeado com o Iraque, em 1980 , o que fez reduzir drasticamente a oferta internacional do produto por dois dos principais produtores mundiais.

16 Fonte: Anuário estatístico do Brasil. Instituto Brasileiro de Geografia e Estatística ï IBGE. 


\subsubsection{A decadência do modelo desenvolvimentista e a ascensão do neoliberalismo}

Os sinais de debilitação econômica vieram com força após os choques do petróleo. A reorganização do capitalismo em nível internacional e sua acelerada financeirização foram responsáveis por desmontar paulatinamente a forma nacional-desenvolvimentista de organização da economia.

A década de 1980 foi batizada como ñdécada perdidaò ${ }^{17}$. Essa designação representa, em grande medida, o que em termos econômicos os anos oitenta significaram para o Brasil: baixos índices de crescimento, inflação fora do controle e uma redução importante da capacidade de investimento, acompanhada de uma crise no balanço de pagamentos do país, incapaz de reter reservas de dólares.

As crises do petróleo na década de 70 assinalavam o grau de vulnerabilidade externa da economia brasileira. Ainda que o processo de desenvolvimento predecessor, no país, tenha assumido forte caráter nacional, alicerçado no crescimento do mercado doméstico, seu financiamento dependia diretamente dos mercados externos e de investimentos estrangeiros, para que pudesse proceder à substituição de importações e aos grandes projetos e obras de infraestrutura (como Itaipu, Ponte Rio-Niterói, a Transamazônica, por exemplo).

Esta dependência de mercados e investimentos estrangeiros foi drasticamente ameaçada com as crises de petróleo e a política restritiva de Ronald Reagan, presidente dos Estados Unidos. O FED ï Federal Reserve System, autoridade monetária estadunidense, elevou a taxa de juros a patamares altos, a fim de absorver a liquidez mundial, num período de aperto de crédito nos mercados. Esse receituário era difundido pelos chicago boys, grupo de economistas liberais que acederam aos postos-chaves do governo Reagan e que viam o problema da economia daquele país no excesso de intervenção e tributos do governo.

Os anos 80 no Brasil foram, nesse contexto, voltados à contenção da demanda agregada, desvalorização cambial do Cruzeiro, elevação de preços de derivados do petróleo,

17 A década perdida é um termo utilizado para fazer referência à estagnação econômica da economia da América Latina ao longo da década de 1980, quando se verificou de forma mais ou menos generalizada uma diminuição considerável da produção industrial e um menor crescimento da economia como um todo, muito em razão dos choques do petróleo de fins da década de 1970. Essa década representou o esgotamento do ciclo desenvolvimentista brasileiro, e o fim do milagre verificado na década de 1970. 
dos reflexos da reedição do Plano Nacional de Desenvolvimento ï PND II, e de políticas que marcariam uma profunda crise fiscal do Estado, sobretudo mediante a disponibilização de títulos da dívida pública no mercado interno a altos juros, com o intuito de transformar a dívida externa em dívida interna. ${ }^{18}$

À crise que se figurava na economia brasileira somava-se um contexto de franca decadência dos países socialistas, o que justificava cada vez menos a existência de governos autoritários nos países latino-americanos, apoiados por Washington para conter uma suposta ñameaça vermelhaò na região. De igual modo, a linha política de abrandamento do regime militar, que sucedeu os anos Médici, veio sinalizar a abertura gradual do regime, acompanhada do recrudescimento das mobilizações e greves sindicais. Curiosamente, a ruptura certeira com o regime militar e a adoção de um novo quadro político-institucional, em um contexto que clamava por eleições diretas, por democracia e maior participação popular, que desembocou na promulgação da Constituição de 1988, é um contexto também marcado por uma importante crise econômica.

Deste modo, revisitar a história política e institucional brasileira do século XX nos faz observar que as rupturas político-institucionais brasileiras desse mesmo século XX (1930, 1964, 1985) guardam importante relação com rupturas dos modos de estruturação, organização e hegemonia do capitalismo no país, sempre informado por condicionantes externas. Essa constatação diz respeito a rearranjos institucionais reforçados, apoiados e conduzidos por elites políticas e econômicas diretamente alicerçadas nas transformações internacionais do sistema capitalista.

Assim, 1930 remete-se ao crack de Nova York em 1929, à crise da economia cafeeira e da política das controlada por oligarquias rurais locais, ao impulso da industrialização, e à necessidade de sua organização pelo Estado. 1964 guarda íntima relação com 1959 e a revolução cubana, e o receio norte-americano de que novos países americanos vivenciassem regimes socialistas reais, aliado a certa comoção das elites políticas e econômicas, com o estado intestinal do Brasil, o cenário de crise e baixo desempenho da economia nos anos Goulart, e seu reformismo distributivista. 1985, por sua vez, refere-se ao esgotamento do ciclo

18 Referimo-nos aqui à críse da dívida brasileira, processo que resulta na moratória em 1987, e à recessão econômica que se seguiu. Na década de 1970 o capitalismo mundial começa a dar sinais de um impressionante giro. Trata-se do processo de ñfinanceirizaçãoò, no qual a acumulação ocorre segundo e em razão da lógica da valorização financeira. Os choques do petróleo e a política de juros americana, conhecida como reaganomics, acabaram levando também a um impressionante desequilíbrio das contas externas brasileiras, à dificuldade de financiamento do desenvolvimento e a necessidade de instrumentos auxiliares para garantir reservas ao país. Com isso, a rolagem da dívida e consequentes resgates e débitos junto ao Fundo Monetário Internacional passam a fazer parte do cenário econômico brasileiro. 
industrialização e expansão econômica nas reservas e nos investimentos externos, e que foi enfim colapsado com os choques do petróleo de 1973 e 1979 e a extrema aceleração da financeirização capitalista iniciada em nível global. O modelo de substituição de importações sinalizava, assim, seu crepúsculo.

O cenário de rearranjo institucional, diante do colapso do desenvolvimentismo, fez sucederem, no Brasil, entre 1986 e 1988, distintos planos econômicos que tinham por objetivo contornar a situação inflacionária galopante, represada no período autoritário pelo arrocho salarial e pela política de emissão de títulos do Tesouro Nacional para financiamento de gastos públicos. A segunda metade da década de oitenta assinala uma busca frenética de planos econômicos que faziam uso de instrumentos como o aumento de juros, a diminuição de gastos públicos, a desindexação da economia e o congelamento de preços: Plano Cruzado, Plano Bresser, e Plano Verão, para tentar contornar a inflação descontrolada. Mostraram-se fracassados, apesar de o Plano Cruzado ter obtido relativo êxito no controle da inflação em seu período inicial. Incapazes de superar o ciclo de esgotamento do desenvolvimentismo brasileiro, tais planos não removeram dos anos oitenta a alcunha de ñdécada perdidaò ${ }^{19}$, em que se verificou uma forte estagnação econômica do país.

O período em que a economia brasileira sinalizava sua crise existencial foi renovado por um contexto em que a democracia, as eleições diretas e a assembleia constituinte representariam os anseios por uma nova era, de reconhecimento de direitos de cidadania e dos fundamentos constitutivos de uma sociedade livre, justa e solidária. Foi essa guinada institucional que também abriu certa oportunidade política para uma disputa do controle hegemônico do país. As forças organizativas do neoliberalismo ï classes empresariais que vinham se modernizando, aliadas a setores parceiros de grupos empresariais transnacionais $і$ operaram então com grande vigor nessa disputa, num movimento que vinha apresentando claros sinais de ascensão, sobretudo no plano internacional.

Afinal, após duas décadas de prosperidade e crescimento econômico nada desprezível (1960 e 1970) o capitalismo começava a sinalizar a crise cíclica não apenas no Brasil, mas também em nível mundial. Conforme assinala Paulani (2010, p. 37):

19 Apesar de manifestada como crise inicialmente de endividamento externo, a crise econômica nos anos oitenta se revela de forma abrangente e significativa, se analisarmos alguns dados sobre a economia brasileira: o PIB per capita, que de 1970 a 1980 vinha se expandindo à taxa média de 6,1\% ao ano, diminui $13 \%$ entre 1980 e 1983, oscilando entre altos e baixos até 1989. A renda per capita caiu 0,6\% entre 1980 e 1989 . A participação econômica de trabalhadores sem vínculo empregatício na economia sobe de 41,9 para 47,2\% no mesmo período (1980-1983), enquanto o salário-mínimo sofre sucessivas reduções, passando de 100 dólares no começo da década de 1980, a 47,3 dólares em 1992. (MEDEIROS, 1993; IBGE,1993) 
Um dos fatores mais importantes que permitiu a ascensão dos neoliberais foi a desaceleração cíclica, acontecimento normal depois de duas décadas de forte crescimento econômico, que vem acompanhado de grande volume de investimentos. Em determinada hora, a demanda por investimentos fica suprida e há uma desaceleração, o que é natural. $O$ investimento não acaba, mas cresce a taxas menores, e essa variável reduz o crescimento econômico.

Foi nesse contexto de depressão econômica na década de 80 que moedas foram regularmente desvalorizadas, ou realinhadas com sistemas monetários de conversão, e muitas restrições relativas a trocas comerciais e movimentação financeira para o exterior foram reduzidas. Os instrumentos de política neoliberal foram também direcionados às economias domésticas de muitos países. Em muitos casos, a desregulamentação atingiu ainda os mercados de trabalho, geralmente envolvendo a dessindicalização e a abolição de leis de salário-mínimo, de modo a restringir o consumo das famílias e direcionar o excedente ao investimento privado, em um modelo trickle-down, isto é, um modelo que deposita forte crença no fato de que benefícios e isenções fiscais concedidas a setores empresariais e de negócios, com maior renda e poder aquisitivo, beneficiariam também as classes sociais menos favorecidas, numa espécie de efeito cascata. Além disso, outras medidas complementares iam sendo implementadas, caracterizando o projeto neoliberal, como aquelas direcionadas à redução do gasto público, especialmente através da privatização de empresas estatais e da redução do tamanho da burocracia, dos investimentos em educação, assistência social, saúde, previdência social, transporte e sistema de comunicações. (PRESTON, 1996).

O neoliberalismo não foi, nessas condições, uma experiência inteiramente nova no Brasil, ou algo completamente aleatório, que abateu sobre a organização do processo de desenvolvimento capitalista no país de maneira fortuita. Muito antes pelo contrário, sua existência no Brasil foi condicionada por importantes experiências prévias, em governos em outros contextos, como o de Margaret Thatcher, no Reino Unido (1979-1990), de Ronald Reagan, nos Estados Unidos (1981-1989), e de Augusto Pinochet (1973-1990), no Chile. Tais governos se caracterizaram, de diferentes maneiras e métodos, por adotar os preceitos mais significativos do cânone neoliberal, que encontrava na escola austríaca sua matriz teórica fundante: Carl Menger, Friedrich Hayek e Ludwig von Mises, autores que revisitaram o liberalismo econômico clássico em fins do século XIX e início do século XX e, em alguma medida inspiraram, anos mais tarde, o trabalho intelectual de Milton Friedman, em Chicago. Friedman foi um importante contribuidor da escola monetarista. Para ele, a estabilidade das economias capitalistas dependia de instrumentos monetários, como o controle do volume de 
(FRIEDMAN, 1984)

Essa matriz teórica inspirou um conjunto de reformas e a ascensão de uma agenda liberalizante em plano internacional. Uma agenda que passou a questionar a alta participação do Estado no crescimento das economias, as elevadas taxas de inflação, o nível de gasto e investimento público como fatores interferentes na demanda e oferta, pressupostos que, reduzidos, serviriam ao bom funcionamento do mercado, dentre outros. Neste modelo, podemos destacar uma forte tendência à negação do papel do Estado nacional como sujeito central condutor e executor de políticas públicas. O Estado torna-se, com isto, supervisor, um gerente, deixando de ser agente.

Essa tendência se associa fortemente, por sua vez, a uma perspectiva globalista, cuja principal ideia-força é a de que os países são interdependentes no mercado internacional globalizado e que tal processo, à medida em que se aprofunda, levaria a uma redução das políticas a cargo de deliberação governos: ño poder de decisão transferido investidores, agências, organizações e corporações transnacionais, diluído na força do mercadoò (DINIZ, 2011 , p. 35), porém concentrado nas mãos de poucos agentes organizados por esse mesmo mercado.

Foi precisamente sob essas condições que a agenda política internacional do neoliberalismo ganhou corpo e sistematicidade, em uma reunião realizada em 1989, convocada pelo Institute for International Economics, entre a cúpula de funcionários do governo dos Estados Unidos e de organismos internacionais situados na capital norteamericana, como o Fundo Monetário Internacional (FMI), o Banco Mundial e o Banco Interamericano de Desenvolvimento (BID). A reunião teve como tema ñLatin American Adjustment: how much has happened?ò (ñAjuste na América Latina: quanto aconteceu?ò), em um formato bastante acadêmico e sem uma feição deliberativa. A reunião ganhou importante caráter simbólico, sobretudo para o Brasil, na medida em que foram discutidas e consideradas exitosas as políticas econômicas liberalizantes implementadas por países latino-americanos já em fins da década de oitenta, excetuados o Brasil e o Peru. (BATISTA, 1994) Nessas condições, o Consenso de Washington foi nada mais que uma espécie de ñempurrãoò para o ingresso do Brasil na era da financeirização e da desregulamentação.

Apesar de seu caráter inicialmente não deliberativo, o Consenso de Washington fez ressoar nos meios acadêmicos o discurso de modernização pelo mercado e necessidade de alívio do estrangulamento que o Estado promovia no campo econômico, que seria uma espécie de ñmalò responsável pela crise econômica verificada nos anos oitenta. O 
e os anseios de elites (econômicas e políticas) e passa a ser cotidianamente parte dos discursos de veículos midiáticos, em compromisso com essa nova lógica que passa a organizar o quotidiano da política e da economia mundial. As instituições que participam dessa reunião reforçam, no plano internacional, a ideologia de supremacia dos mercados sobre o Estado, que passa a ser visto como um problema, devendo ser reduzido a um espaço de atuação mínimo necessário.

De forma bastante resumida, podemos destacar os seguintes apontamentos (exigências) resultantes da reunião do Consenso de Washington, que consideram necessário esse novo impulso pela eliminação de barreiras e restrições ao processo de mundialização financeira do capital: abertura comercial, mediante a redução de tarifas alfandegárias em nível mundial, a privatização de estatais, a redução de gastos públicos, a disciplina fiscal (enquanto ferramenta de controle inflacionário, evitando o expansionismo), a reforma tributária, que reduza e otimize os impostos sobre produção e circulação de bens e serviços, sobretudo os serviços bancários e financeiros, a desregulamentação trabalhista (que supostamente tenderia a favorecer a contratação), o estímulo a investimentos estrangeiros diretos (eliminando barreiras à instalação de filiais de multinacionais e as restrições para o investimento de capitais), e a prática de taxas de juros de mercado e câmbio também de mercado, associados diretamente às intervenções das autoridades monetárias.

O neoliberalismo ganha força ao longo dos anos, mas suas origens remontam a um processo iniciado com a crise do petróleo nos anos setenta. Nas palavras de Harvey (2011, p. 16), o neoliberalismo:

Assumiu a retórica da liberdade individual, autonomia, liberdade pessoal e as virtudes da privatização, livre-mercado e livre-comércio, legitimou políticas draconianas destinadas a restaurar e recompor o poder da classe capitalista.(...) Um dos princípios básicos pragmáticos que surgiu na década de 1980, por exemplo, foi o de que o poder do Estado deve proteger as instituições financeiras a todo custo. Esse princípio, que bateu de frente com o não intervencionismo que a teoria neoliberal prescreveu (é ) de modo nu e cru, (...) era: privatizar os lucros e socializar os riscos.

Nessa esteira o Brasil caminhou ao longo da década de 1990. A redemocratização do país, se por um lado significou a possibilidade de escolha direta dos representantes que assumiriam o primeiro governo eleito democraticamente em 1989, por outro, abriu espaço para a oportunidade política de que os setores das elites políticas e econômicas alinhados com as diretrizes de Washington vissem atendidos seus anseios. Foi precisamente com o candidato Fernando Collor de Mello que, após o pleito eleitoral de 1989, o país ingressou sua economia na lógica neoliberal. 
claro, na medida em que se verificaram: 1. o objetivo de rompimento com a indexação econômica, por meio da redução da liquidez na economia, do bloqueio de depósitos à vista, de fundos e também da poupança, 2. a promoção de uma reforma administrativa e fiscal, que pressupunha a redução de subsídios, incentivos e isenções e custos de funcionamento da máquina pública, a redução do custo de rolagem da dívida pública e a promoção de programa de privatizações, e 3. A mudança do regime cambial fixo para o flutuante e liberalização do comércio exterior, com redução das tarifas de importações, conhecida como ñaberturaò do país às importações. (GREMAUD, 2011) Incapaz de controlar a inflação mesmo com sua política forçosa de superávits fiscais, que veio acompanhada de uma baixa arrecadação, o primeiro presidente eleito democraticamente após a ditadura foi impedido de permanecer no exercício do mandato, após a série de denúncias sobre escândalos de corrupção que o acompanharam.

Após o rápido mandato de Collor, o Brasil volta a reforçar os preceitos do Consenso de Washington com os mandatos de Fernando Henrique Cardoso (1995-1998 e 1999-2002). Com a missão de combater a inflação no país, o governo de Cardoso foi responsável por articular um complexo ajuste para a estabilização monetária. O plano, batizado de Plano Real e gestado no governo precedente (em que o vice-presidente Itamar Franco assumiu a cadeira após o impedimento de Collor), enquanto Cardoso ocupou a pasta da Fazenda, iniciou-se com um forte ajuste fiscal, cortando gastos em despesas de investimento e pessoal e aumento da arrecadação, e também com a criação de imposto temporário sobre movimentações financeiras. No plano discursivo, o presidente antecipou sua política econômica e administrativa de forma bastante clara:

Que a própria complexidade da matriz produtiva implantada excluía novos avanços da industrialização por substituição de importações. Que a manutenção dos mesmos padrões de protecionismo e intervencionismo estatal que sufocava a concorrência necessária à eficiência econômica e distanciaria cada vez mais o Brasil do fluxo de inovações tecnológicas e gerenciais que revolucionavam a economia mundial. E que a abertura de um novo ciclo de desenvolvimento colocaria necessariamente na ordem do dia os temas da reforma do Estado e de um novo modo de inserção do País na economia internacional. (...)

A remoção destes entulhos do velho modelo aumentará enormemente a eficiência global da economia brasileira. Reduzirá os custos das empresas. Reduzirá os custos da política econômica para o próprio governo, hoje sobrecarregado por subsídios e pela administração de sua parafernália regulatória. E redundará em preços finais mais baixos (...)

O processo de privatização deve ser acelerado e estendido a outras atividades e empresas dos setores de energia, transporte, telecomunicações e mineração. (é ) $\mathrm{O}$ próprio conceito de privatização deve ser ampliado: venda de empresas com controle acionário direto ou indireto da União; venda de participações acionárias, venda de ativos imobilizados, concessões de serviços públicos, incluindo a responsabilidade por novos investimentos, contratos de administração de serviços com empresas 
ONGs como organizações neo-governamentais. Formas inovadoras de articulação da sociedade civil com o Estado (é ) descentralização e parceria com a comunidade, portanto, são as linhas mestras das ações do futuro governo no sentido de universalizar o acesso a serviços de saúde e a um ensino fundamental de boa qualidade. (CARDOSO, 1994, pp. 4-9) (grifos nossos)

O governo de Fernando Henrique, por menos que o próprio presidente aceite a designação de neoliberal, foi marcado por uma diminuição sensível da participação do Estado na execução de políticas públicas, redimensionando o papel da execução direta de serviços públicos, e da intervenção estatal na esfera econômica, após sistemáticas reforma da administração pública e reorganização da política econômica, consubstanciada na elaboração do plano Real e em sua manutenção nos anos seguintes. Segundo o ex-presidente:

Por motivos de luta político-ideológica, assim como por pouca informação, muita gente quer confundir ou confunde esta nova postura com o antigo ñneo-liberalismoò. Mas a verdade é que se trata da reconstrução do Estado para ser capaz de, respeitadas as limitações do mercado, atender com não menor devoção aos anseios da solidariedade e de novas formas de atuação. Nunca, porém, de destruição ou de minimização do Estado e da atuação dos governos. (CARDOSO, 1998, p. 7)

A implementação da agenda neoliberal no Brasil foi um processo conduzido ao longo da década de 1990: a necessidade de atração de investimentos estrangeiros e constituição de reservas monetárias significavam uma inserção na nova ordem de funcionamento do capitalismo em nível internacional. Nesta ordem, as políticas públicas ficam constrangidas e dificultadas, se não houver capacidade de investimento. A dívida pública e sua possibilidade de ser rolada são também poderosos instrumentos que financiam a capacidade de investimento do Estado (apesar de não novos), que coloca seus títulos no mercado para que os investidores possam negociá-los. A confiança nesses títulos e papéis do governo, conforme os níveis de reservas cambiais e taxas de retorno $\ddot{i}$ mensurada pelas taxas de juros da dívida pública $і ̈$ garantem a permanência de governos e sua credibilidade internacional, num poderoso jogo de xadrez das nações na atualidade. Agências de risco passam a traduzir esse nível de confiança e a operar também nesse cenário. A autoridade monetária recorre ao aumento frequente das taxas de juros, como fica sinalizado no período do governo FHC, e a equipe econômica composta por Pedro Malan, Ministro da Fazenda, e Gustavo Franco e Armínio Fraga, no Banco Central.

As medidas adotadas pelo governo de Fernando Henrique Cardoso podem ser caracterizadas como uma fratura nas relações entre Estado e mercado que alicerçavam o 
econômicas do país com a lógica internacional de funcionamento da economia, e uma revisão e aprofundamento sistemáticos das instituições e do modus operandi da máquina pública, sob um novo paradigma econômico, informado pela ordem internacional. Nesse paradigma, podemos destacar a redução da participação estatal nas atividades econômicas, a reinauguração do Plano Nacional de Desestatização ï PND (que já havia sido objeto de lei sancionada no governo Collor), aprovado pela Lei $\mathrm{n}^{\circ}$ 9.491, de 9 de setembro de 1997, o controle da inflação por meio de instrumentos monetários ï com a adoção do exitoso Plano Real, que veio reforçar uma espécie de hegemonia de projeto para o país, com larga penetração discursiva nos veículos midiáticos e aprovação importante de diferentes setores: empresariado, burocracia e classes médias urbanas, e mesmo por camadas populares, que viam a corrosão de suas rendas salariais com a inflação ser categoricamente reduzida. O êxito do Plano acabou não apenas por estimular que a Constituição fosse emendada, a fim de garantir a possibilidade de reeleição do presidente, mas também lhe garantiu, efetivamente, um segundo mandato.

Merecem destaque também, no período, a quebra dos monopólios dos setores de petróleo e telecomunicações, o saneamento do sistema financeiro - com a absorção de instituições financeiras em crise de insolvência (Bamerindus, Nacional, Banespa, Banerj) por grupos de instituições financeiras privados e com a facilitação da entrada de bancos estrangeiros no país, além do estímulo à conglomeração no setor financeiro, a reforma parcial da Previdência Social, postergando o tempo de contribuição e as idades mínimas exigidas para a aposentadoria, além da aprovação do fator previdenciário para o Instituto Nacional de Seguridade Social ï INSS, sem contar a renegociação das dívidas estaduais e a aprovação da Lei de Responsabilidade Fiscal - LRF (Lei Complementar $n^{\circ} 101$, de 4 de maio de 2000), estabelecendo tetos para despesas com pagamento de pessoal e proibição de renegociações de dívidas e a adoção de um programa com metas fiscais rígidas. Além disso, a quebra dos monopólios levou também à forte regulação do Estado por meio de agências: isto reduziu a execução direta de políticas públicas, e fez o Estado passar a regular setores como energia, comunicações, saúde privada e outros tantos.

O programa em curso no país, que enxugou o tamanho e a forma de operação da máquina pública, e finalmente conseguiu controlar a inflação, foi abalado pela crise financeira que se abateu em 1999: o ancoramento cambial do plano levou a um desgaste das contas externas do país e o agravamento da crise fiscal, exatamente porque o Brasil não contava com instrumentos de politica fiscal consolidados (uma vez que a LRF é do ano 2000). O governo 
sua capacidade de financiamento. Somado a isso, o cenário de crise precedente das economias de países emergentes, como o México, em 1995, os Tigres Asiáticos (sobretudo Tailândia e Coreia do Sul), em 1997 e da Rússia em 1998, afetou fortemente o Brasil no ritmo de entrada de capitais na economia doméstica. (GIAMBIAGI, 2011)

Diante dessa crise, a moeda brasileira teve uma forte desvalorização, após seu período de sobrevalorização, o que gerou saldos negativos na balança comercial e na conta de transações correntes, acentuando a vulnerabilidade da economia brasileira e sua dependência com relação ao fluxo de capitais estrangeiros. (FILGUEIRAS, 2006, p. 2). É exatamente nesse período que três instrumentos ingressam como fundamentais à política macroeconômica brasileira, a fim de evitar as crises e choques externos, e que passam a constituir uma agenda monetarista dessa política para os anos seguintes. O câmbio fixo foi abandonado, pois era necessário garantir que os capitais investissem com respaldo na capacidade de financiamento da própria dívida do governo (confiança dos credores e credibilidade do governo) e que os preços se mantivessem em um nível aceitável, garantindo a reputação, credibilidade e transparência exigidas para coordenar as expectativas do mercado e evitar que, com a desvalorização do câmbio, os preços subissem. Para contornar essa crise, nascia assim o chamado ñtripéò da macroeconomia brasileira: constituído por câmbio flutuante, superávit primário e metas de inflação, instrumentos da convenção institucionalista, ainda presentes na política macroeconômica atual.

Outro problema enfrentado pelo governo FHC foi a crise energética no país. Em razão da falta de investimento na expansão e na capacidade produtiva do setor, o conhecido racionamento de energia levou à retração do consumo, da produção e do próprio investimento na economia brasileira. Esse cenário $\ddot{i}$ em que as pressões externas também aumentavam significativamente, com a crise cambial argentina, e a insegurança dos mercados diante dos ataques terroristas às Torres Gêmeas, em 2001 ï abortou qualquer promessa de crescimento econômico vigoroso do pais, e deixou um quadro de juros altos, baixa capacidade de financiamento, taxa de desemprego elevada, que alcançou 12,6\% em 2002 (BRASIL, 2002), crescente endividamento público, em razão das taxas de juros altas praticadas para conter as pressões inflacionárias, a fuga de capitais e uma maior desvalorização monetária. (GREMAUD, 2011).

Os anos de governo Cardoso (1995-2002) representaram o realinhamento da concepção do Estado enquanto indutor do desenvolvimento, ao conceber sua organização e funcionamento sob formas de delegação de serviços públicos, concessões, privatizações e 
políticas públicas. No que diz respeito à política econômica, sua maior herança foi, como vimos, a readequação da estabilidade inflacional ï e aqui há que se frisar que o monetarismo passou a ser uma forma decisiva de organização e funcionamento da economia brasileira, alicerçada sob o Plano Real ï por meio da adoção do tripé macroeconômico câmbio flutuante, superávit primário e metas de inflação. Esse período também apresenta um nível de expansão instável do Produto Interno Bruto ï PIB, com baixo dinamismo da economia brasileira, o que parece ser também a tônica da economia nacional nos anos posteriores. ${ }^{20}$

\subsubsection{Uma trajetória dependente: a hibridização do neodesenvolvimentismo}

O fim da era FHC representou o enfraquecimento dos preceitos de uma economia cada vez menos regulamentada, que deslocava o centro de atenção do Estado para o mercado, traduzia a atuação do Estado na economia via formulismo monetário, promovia a dessindicalização e abria espaço para o agigantamento e inserção de grupos de instituições financeiras. Se essas características foram os tons da situação econômica ao longo da década de 90, o mesmo não se pode dizer dos anos 2000, sobretudo a partir de 2003.

A eleição presidencial de 2002 foi vencida por Luiz Inácio Lula da Silva, uma das figuras mais emblemáticas da história do Partido dos Trabalhadores - PT, conhecido por sua atuação como liderança sindical no ABCD (região formada pelos municípios de Santo André, São Bernardo do Campo, São Caetano do Sul e Diadema) paulista. Desde a fundação do PT em 1980, o partido, que agregava diferentes setores organizados da esquerda, intelectuais, setores de base de movimentos sociais urbanos e campesinos, setores progressistas da Igreja Católica, agregava também aqueles de base ideológica gramsciana ${ }^{21}$ e leninista ${ }^{22}$, erepresentava um programa ligado a uma agenda de esquerda, espelhada no chamado socialismo democrático. ${ }^{23}$ A vitória de Lula no pleito eleitoral deu fôlego às esperanças por

20 Entre 1994 e 2002, o Produto Interno Bruto Brasileiro cresceu, em média, 2,7\% ao ano, chegando a uma variação próxima a zero no biênio 1998-1999, ano da crise cambial do Plano Real. (IBGE; FGV, 2013)

21 O Partido dos Trabalhadores, adotou, desde sua fundação, caros princípios formulados por Antônio Gramsci, como a teoria da hegemonia, a ideia de fortalecimento da sociedade civil (enquanto luta de classes) e a construção de um bloco que produzisse reformas que reforçassem a democracia condição para a onstituição de um novo modelo de socialismo). Conforme Carlos Nelson Coutinho, mesmo na década de noventa essa marca ideológica é ainda forte, como se constatou no VII Encontro Nacional do Partido, realizado em 1990 em São Paulo, em que, das oito teses apresentadas, seis utilizavam explicitamente conceitos gramscianos. (COUTINHO, 1999, p. 298)

22 Neste sentido, ver artigo de Reginaldo Benedito Dias: Ação Popular Marxista-leninista e a formação do PT. (DIAS:2009)

23 No discurso de Lula à $1^{\text {a }}$. Convenção Nacional do PT, o sindicalista afirma que o socialismo que queremos se definirá por todo o povo, como exigência concreta das lutas populares, como resposta política e econômica 
eleitorado independente, assumindo a necessidade de superação dos efeitos das crises antecedentes, marcadas por recessão e desaceleração econômica.

Desde a campanha de 2002, o discurso do Partido dos Trabalhadores foi sendo abrandado, readequado em tons mais moderados, versando-se em um progressismo constituído por uma ampla frente, mobilizada por reformas econômicas. Assumindo compromissos nacionais e internacionais, o PT divulgou naquele ano a Carta ao Povo brasileiro, documento com o intuito de apaziguar a tensão pré-eleitoral verificada pelos mercados financeiros deflagrada pela possibilidade concreta de eleição do primeiro presidente ligado a um partido abertamente ligado ao movimento sindical e a setores de esquerda menos moderados no país. Ressaltamos alguns pontos nesse documento:

A crescente adesão à nossa candidatura assume cada vez mais o caráter de um movimento em defesa do Brasil, de nossos direitos e anseios fundamentais enquanto nação independente. Lideranças populares, intelectuais, artistas e religiosos dos mais variados matizes ideológicos declaram espontaneamente seu apoio a um projeto de mudança do Brasil. Prefeitos e parlamentares de partidos não coligados com o PT anunciam seu apoio. Parcelas significativas do empresariado vêm somar-se ao nosso projeto. Trata-se de uma vasta coalizão, em muitos aspectos suprapartidária, que busca abrir novos horizontes para o país. (é ) Será necessária uma lúcida e criteriosa transição entre o que temos hoje e aquilo que a sociedade reivindica. $\mathrm{O}$ que se desfez ou se deixou de fazer em oito anos não será compensado em oito dias. $\mathrm{O}$ novo modelo não poderá ser produto de decisões unilaterais do governo, tal como ocorre hoje, nem será implementado por decreto, de modo voluntarista. Será fruto de uma ampla negociação nacional, que deve conduzir a uma autêntica aliança pelo país, a um novo contrato social, capaz de assegurar o crescimento com estabilidade. (é ) À parte manobras puramente especulativas, que sem dúvida existem, o que há é uma forte preocupação do mercado financeiro com o mau desempenho da economia e com sua fragilidade atual, gerando temores relativos à capacidade de o país administrar sua dívida interna e externa. É o enorme endividamento público acumulado no governo Fernando Henrique Cardoso que preocupa os investidores. (é ) Trata-se de uma crise de confiança na situação econômica do país, cuja responsabilidade primeira é do atual governo. Por mais que o governo insista, o nervosismo dos mercados e a especulação dos últimos dias não nascem das eleições.(...) Superando a nossa vulnerabilidade externa, poderemos reduzir de forma sustentada a taxa de juros. Poderemos recuperar a capacidade de investimento público tão importante para alavancar o crescimento econômico. Esse é o melhor caminho para que os contratos sejam honrados e o país recupere a liberdade de sua política econômica orientada para o desenvolvimento sustentável. (é ) Ninguém precisa me ensinar a importância do controle da inflação. Iniciei minha vida sindical indignado com o processo de corrosão do poder de comprar dos salários dos trabalhadores. (é ) Quero agora reafirmar esse compromisso histórico com o combate à inflação, mas acompanhado do crescimento, da geração de empregos e da distribuição de renda, construindo um Brasil mais solidário e fraterno, um Brasil de todos. (...)A volta do crescimento é o único remédio para impedir que se perpetue um círculo vicioso entre metas de

global a todas as aspirações concretas que o PT seja capaz de enfrentar. (é ) O socialismo que nós queremos irá se definindo nas lutas do dia a dia, do mesmo modo como estamos construindo o PT. (PARTIDO DOS TRABALHADORES, 1998, p. 114) 

impedir que a dívida interna aumente e destrua a confiança na capacidade do governo de honrar os seus compromissos. (...)Mas é preciso insistir: só a volta do crescimento pode levar o país a contar com um equilíbrio fiscal consistente e duradouro. A estabilidade, o controle das contas públicas e da inflação são hoje um patrimônio de todos os brasileiros. Não são um bem exclusivo do atual governo, pois foram obtidos com uma grande carga de sacrifícios, especialmente dos mais necessitados. (LULA DA SILVA, 2003) (grifos nossos)

Essa sinalização de uma proposta de política econômica fez-se parcialmente coerente a seus propósitos ao longo dos anos de governo Lula: de fato, sua eleição foi fruto de uma ampla negociação $\ddot{i}$ uma vez que fortes setores do empresariado financiaram ${ }^{24}$, e uma forte base de apoio se consolidou para sua reeleição, angariando até mesmo o Partido do Movimento Democrático Brasileiro ï PMDB.

Uma interessante análise sobre a transformação do arco de alianças e a predominância ideológica no seio do Partido dos Trabalhadores é apresentada por André Singer, que afirma haver um abandono da posição anticapitalista e da política de alianças petista, com o predomínio de uma defesa da ordem capitalista, com preservação da estabilidade econômica, de estabilidade monetária e fiscal e acordos políticos com partidos à direita, como o extinto Partido Liberal (Atual Partido da República), com o PMDB, e mesmo o Partido Trabalhista Brasileiro (PTB), nos governos Lula. (SINGER, 2012). Essa base de apoio foi fundamental não só à campanha, mas também no apoio político aos anos de governo Lula, e foi beneficiada com expressiva participação na vida política nacional.

Também se observou a geração de 15,3 milhões de empregos formais, entre celetistas e estatutários (BRASIL, 2011), a preservação do superávit primário (que, na série histórica iniciada em 2002, apresentou taxas expressivas) e a preservação de contratos (sem declarar moratória, reestatizar empresas privatizadas ou estatizar propriedades privadas, além da redução dos juros ${ }^{25}$. Seu principal desafio, em que deixou a desejar, foram os índices de crescimento da economia brasileira, que permaneceram baixos e caracterizavam-na como economia de baixo dinamismo e instável. O que se verificou após a eleição de Lula e a ascensão do governo foi uma certa continuidade do modelo de crescimento instável de baixo

24 Conforme podemos observar no sítio eletrônico do TSE, a Companhia Vale do Rio Doce, doou algo em torno de 4 milhões de reais à campanha do candidato Luiz Inácio Lula da Silva. Camargo Corrêa, OAS e Andrade Gutierrez, bancos como Itaú, Bradesco, ABN Amro Bank e siderúrgicas (CSN e Gerdau), além da fabricante e sucos de laranja Cutrale, constam da lista dos principais financiadores da campanha presidencial no ano de 2002. (BRASIL, 2011)

25 Entre as oscilações da taxa Selic no período, a taxa de juros geral revelou-se em 22 de janeiro de 2003, num patamar de 25,36\% a.a., chegando, ao final do mandato de Lula no segundo governo, em 08 de dezembro de 2010, a 10,66\% a.a. Apesar da redução sensível, o valor geral das taxas de juros reais, isto é, taxas efetivas, que não são refletidas pelas taxas nominais reportadas, variaram de $47,32 \%$ a.a. para $29,35 \%$ a.a. Apesar da redução significativa, o Brasil ainda figura como um dos países com as maiores taxas reais de juros. 

do crescimento percentual do Produto Interno Bruto Ï PIB brasileiro, ao longo das décadas de noventa e a primeira década dos anos dois mil, quando tanto o PSDB quanto o PT estiveram à frente dos governos e de suas composições majoritárias. Conforme o quadro a seguir:

\section{Figura 2: Evolução Histórica do Produto Interno Bruto Brasileiro (1995-2010) ${ }^{26}$}

\begin{tabular}{|c|c|}
\hline Ano & \% de variação do PIB \\
\hline 1995 & 4,2 \\
\hline 1996 & 2,2 \\
\hline 1997 & 3,4 \\
\hline 1998 & 0 \\
\hline 1999 & 0,3 \\
\hline 2000 & 4,3 \\
\hline 2001 & 1,3 \\
\hline 2002 & 2,7 \\
\hline 2003 & 1,1 \\
\hline 2004 & 5,7 \\
\hline 2005 & 3,2 \\
\hline 2006 & 4 \\
\hline 2007 & 6,1 \\
\hline 2008 & 5,2 \\
\hline 2009 & $-0,3$ \\
\hline 2010 & 7,5 \\
\hline
\end{tabular}

É possível observar certa instabilidade do crescimento econômico brasileiro no período indicado, que oscila em geral em torno de um centro de crescimento médio ligeiramente superior a 3 porcento ao ano, com anos de maior expressão e anos atípicos, com recessão ou retração econômica. Esse quadro é o que podemos caracterizar como de baixo dinamismo e crescimento instável, que se verifica ao longo dos anos.

A combinação de fatores internacionais, somada à política de desenvolvimento e ao modus operandi da política macroeconômica ensejaram ñtaxas muito baixas de expansão do produto, e extremamente voláteis para a economia brasileiraò. (AMITRANO, 2006, pp. 274- 
tenha apresentado alguns anos com maior otimismo em relação ao crescimento do produto interno bruto, e às taxas de investimento e de emprego, em geral esse modelo de crescimento é o que predominou no governo Lula.

Quais as razões para a continuidade desse modelo? Nesta seção, buscamos analisar o que seria uma espécie de continuidade da trajetória econômica do país, refletindo sobre a convenção de desenvolvimento chamada de neodesenvolvimentismo que, como vimos no início deste capítulo, guarda importantes semelhanças com o neoliberalismo e sua matriz institucionalista e com o modelo desenvolvimentista de anos anteriores.

A análise desse modelo se estrutura sob o entendimento ferramental de que as instituições justapõem lógicas distintas de ordem política, cada qual com suas bases temporais. Vários arranjos institucionais fazem uma política emergir em tempos distintos e por configurações históricas também distintas. Deste modo, as várias peças de uma determinada política ñão formam um todo coerente, perfeitamente integrado ou suficientemente homogêneoò. (THELEN, 1999, p. 382, trad. do autor). Para a compreensão do neodesenvolvimentismo, essa abordagem implica dizer que certas heranças são contextuais, e acabam por desenhar, na experiência cotidiana, o próprio conceito, que não pode ser anterior à forma de organização e operação da política. Vale frisar, corroborando a opção teórica da reflexão aqui proposta: a realidade (econômica) é objeto de análise e reflexão, da qual se apreendem e se formulam conceituações. A realidade não é conformada por teorias, mas informa as teorias que tentam aprisioná-la no saber científico, racional.

Portanto, ao adotarmos a compreensão de que o neodesenvolvimentismo é uma opção de política de desenvolvimento, estamos nos referindo ao fato de determinados atores, num leque de opções e referidos num contexto maior, escolherem adotar algumas decisões e definir o conteúdo de uma política econômica, (com claros reflexos sociais) seja por motivos puramente racionais, cálculos entre custos e benefícios, formações, visões de mundo e experiências pessoais desses agentes, trajetórias de formação ideológico-partidária ou mesmo por percepções externas que não necessariamente impliquem valoração ou avaliação impactante sobre resultados e práticas dos próprios governos.

O neodesenvolvimentismo torna-se, assim, nas duas primeiras décadas do século XXI, uma forma hegemônica de opção econômica no Brasil, no momento em que forças políticas se organizaram em torno dessa opção, defendendo-a e viabilizando sua proposta de crescimento com transferência de renda. A eleição de Lula, nesse sentido, foi resultado da contraposição ao modelo desgastado de matriz neoliberal dos anos de Fernando Henrique Cardoso, e a necessidade de superação de um contexto que estrangulava investimentos, 
fvel a choques externos, aplicava uma política de base fortemente monetarista e aprofundava, em meio a crises de recessão, desigualdades sociais, com diminuição dos níveis de emprego e a corrosão do poder aquisitivo das classes trabalhadoras.

Como resposta a esse contexto, o PT reforça a tonalidade de seu discurso comprometido com a defesa das classes trabalhadoras e de grupos sociais à periferia do processo de desenvolvimento capitalista. Apoiado em sua própria formação, constituída em bases fortes de movimentos organizados da sociedade civil, o PT rechaça a política neoliberal dos anos FHC, e apresenta-se como portador de um projeto político de país distinto, democrático-popular, que se propunha capaz de promover a inclusão de setores historicamente excluídos da vida política, social e econômica brasileira.

No entanto, o PT se instrumentalizou no campo de disputa política, tendo abandonado o projeto e certo discurso avesso à lógica capitalista, que marcaram sua fundação, e angariado apoio entre lideranças e setores empresariais da burguesia interna brasileira, defensores de um novo modelo econômico para o Brasil. A constituição do projeto neodesenvolvimentista dependeu, desta maneira, de um convencimento de diferentes setores produtivos brasileiros, que apoiaram a candidatura de Lula à Presidência da República e foram fundamentais à linha política adotada nos anos desse governo.

Ao assumir o governo, o desenho do projeto neodesenvolvimentista é estruturado por uma frente política dirigida por grandes setores do empresariado, urbano e rural, e destinado a um envolvimento $\ddot{i}$ ainda que marginal - de classes trabalhadoras tradicionalmente excluídas do bloco no poder (BOITO JR., 2012) ï baixa classe média, operariado, campesinato e trabalhadores da massa marginal, aos quais são voltados esforços do governo central no sentido de elevar seu nível de renda, seja pela política de valorização salarial, seja por programas de transferência de renda. Deste modo, o neodesenvolvimentismo se alicerça em uma forte base de apoio político. (Ibidem) Além de enfrentar, ao menos no plano discursivo, o campo e a experiência neoliberal predecessora, assumindo a vontade de criar um novo pacto social no Brasil, coordenando ações voltadas tanto a setores tradicionais do empresariado, quanto a grupos sociais menos favorecidos das classes trabalhadoras.

Em linhas gerais, a construção do conceito de neodesenvolvimentismo está, assim, fortemente associada à tese apresentada por André Singer, em sua obra ñOs sentidos do lulismoò. Segundo o autor: 

crise do ómensalãoô um realinhamento eleitoral que se cristaliza em 2006, surgindo o ñulismoò. $\mathrm{O}$ aparecimento de uma base ñulistaò, por sua vez, proporcionou ao presidente maior margem de manobra no segundo mandato, possibilitando acelerar a implantação do modelo áliminuição da pobreza com manutenção da ordemô esboçado no primeiro quadriênioò. (SINGER, 2012, p. 13)

Do ponto de vista político, a base de apoio do modelo petista de administração e condução da política econômica alicerça-se no que Singer caracteriza como ñoase lulistaò, eleitorado progressivamente beneficiado pelo processo de inclusão de renda de classes mais baixas, ao mesmo tempo que satisfaz os interesses de diferentes setores produtivos $і$ empresários da indústria automobilística, de eletrodomésticos, roupas, alimentos e outros, impulsionados pelo reaquecimento e expansão do mercado interno, sem alterar significativamente a pauta de exportações brasileiras ï baseada sobretudo em commodities, e, o mais importante: sem promover qualquer alteração significativa na entrada de capitais financeiros no país, bem como na forma de rolagem e endividamento público, pela emissão de títulos da dívida do tesouro nacional.

Sob esse aspecto, o neodesenvolvimentismo caracteriza-se como uma espécie de concertação econômica, que busca, pela acomodação de diferentes grupos, dispor de microrreformas nas formas de funcionamento do capitalismo no Brasil sem, contudo, confrontação radical (nas suas raízes constitutivas) ou incisiva sobre suas formas de operação. Trata-se de uma opção política estratégica, que não visa tensionar os fundamentos essenciais da macroeconomia institucional. Garante com isto os ganhos tradicionais de setores financeiros e especulativos, sustenta o empresariado de grandes obras e projetos que contrata com o Estado, além de promover, conforme condições conjunturais, universalização de acessos e políticas, e ganhos marginais a setores historicamente excluídos.

Do ponto de vista econômico, a forte inspiração do modelo neodesenvolvimentista é keynesiana, uma vez que o crescimento econômico almejado é alavancado pela ação do Estado, que tem por objetivo aumentar a renda das famílias, sobretudo as mais pobres, excluídas dos processos de produção e circulação de bens e serviços, seja por uma política de transferências fiscais, por valorização do salário-mínimo e qualificação de mão-de-obra a fim de gerar maior empregabilidade, além de investir em infraestrutura e em obras de construção civil. (ERBER, 2011). Nesse sentido, o neodesenvolvimentismo propõe redução das desigualdades sociais, mas o faz de maneira marginal, limitada por seu contexto.

O mote do neodesenvolvimentismo, ao menos no plano discursivo, é o de crescimento com redução de desigualdades, que aponta a existência de um círculo ñvirtuosoò resultante 
ao processo de crescimento econômico sustentado pelo ingresso nas cadeias produtivas e consumidoras de pessoas que estiveram, durante anos, à margem da economia capitalista no Brasil. A inclusão de famílias trabalhadoras pobres no mercado de consumo teria, nessa acepção, contribuído a certa retomada do crescimento econômico, à capacidade estatal de cumprir compromissos fiscais e respaldar sua capacidade também de organizar suas atividades e financiar políticas públicas. A figura a seguir tenta traduzir de forma simplificada esse ciclo:

\section{Figura 3: Ciclo ñvirtuosoòde inclusão de renda e crescimento econômico ${ }^{27}$}
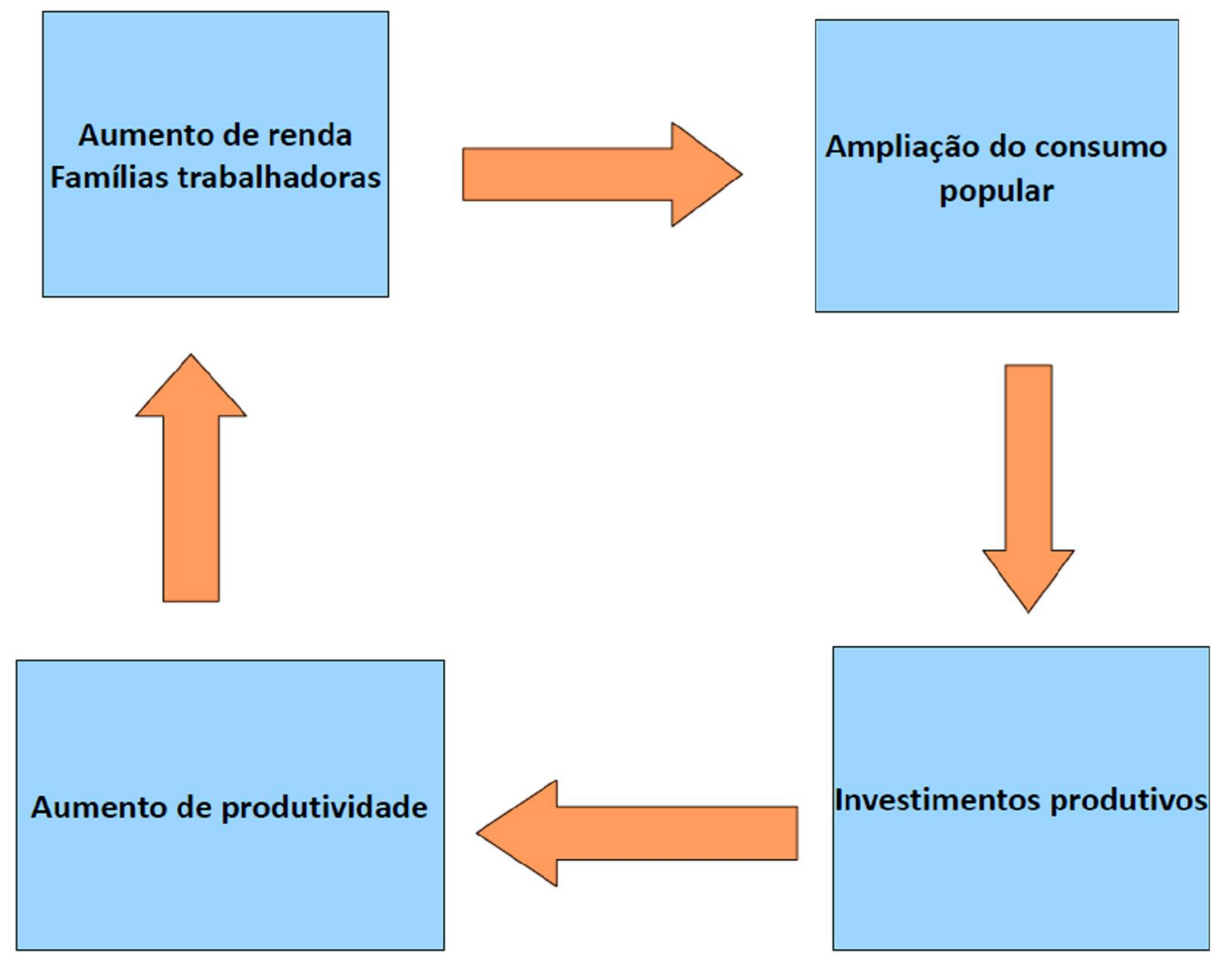

A figura representa o que se tornou o trunfo dos governos petistas ao longo dos últimos anos, sobretudo por meio dos programas de transferência de renda (combinação entre Bolsa-Família, Benefício de Prestação Continuada e garantia de uma Previdência Social universal, inclusive a trabalhadores do campo), além de uma política de valorização do

\footnotetext{
${ }^{27}$ Fonte: Desenvolvimento econômico Evolução e estado atual do pensamento no Brasil. Apresentação de Ricardo Bielschowsky CEPAL na Universidade Federal da Bahia/SIAGS/NEPOL. Dezembro de 2004
} 
oduziu, gradualmente, um aumento de renda das famílias trabalhadoras, que passaram a demandar por mais bens e serviços em diferentes regiões do país (uma vez que as políticas foram estruturadas de forma universalista, com um Cadastro Único que acompanha o perfil e os benefícios sociais a que fazem jus determinada família). $\mathrm{O}$ aumento $\ddot{i}$ e em alguns casos surgimento de demandas até então inexistentes fez aquecer a economia em diferentes regiões do Brasil, e exigiu também maiores investimentos que incrementassem a produção nessas localidades $і ̈$ ou diminuíssem seus custos. Com isto, o aumento da produtividade passou a reforçar e fechar o ciclo de aumento de renda das famílias trabalhadoras.

Esse modelo, pelo menos em tese, ofereceu uma significativa inserção de segmentos sociais até então fortemente excluídos da economia de mercado, e caracterizou expressivamente os governos Lula, em que foram expandidos os programas sociais de transferência de renda condicionada. Os resultados dessa expansão de programas sociais são medidos e visíveis. Para se ter uma ideia, entre 2003 e 2011, a população de extremamente pobres reduziu-se em 4,7 pontos percentuais, a população de pobres decresceu 9,6 pontos percentuais e a de vulneráveis sofreu queda de 1,2 pontos percentuais, além do que a população não pobre do país aumentou em 15,4 pontos percentuais no mesmo período. (IBGE, 2003-2011).

Além dessa política, que alicerçou um modelo de crescimento econômico com inclusão social, os recentes governos petistas redimensionaram o papel do Estado, ao priorizar investimentos em infraestrutura, com a formulação do Programa de Aceleração do Crescimento ï PAC, em áreas como energia, transporte e habitação, mediante financiamento do BNDES ou mesmo do Estado, investimento em inovação, por meio de incentivos fiscais e crédito subsidiado e subvenções. (ERBER, 2011). A maior participação do Estado também em outros setores, como a agricultura familiar, com a concessão de linhas de créditos, via bancos ou fundos públicos (Banco do Brasil e Caixa Econômica Federal) no âmbito do Programa Nacional de Fortalecimento da Agricultura Familiar ï Pronaf, a ampliação de vagas e criação de novas Instituições Federais de Ensino Superior e outras tantas medidas foram sendo construídas ao longo dos últimos anos no país, formando uma agenda que seguramente redimensionou a importância do Estado no fomento, incentivo e execução de ações, sejam universalistas ou focalizadas, desconstituindo o desenho que o pusesse na condição de ñEstado mínimoò.

O neodesenvolvimentismo, assim, é um conceito que foi sendo construído ao longo dos anos: à medida em que eram acumuladas experiências sobre o funcionamento da 

acadêmicas, jornalísticas, políticas, eram produzidas. O caráter nacionalista desse modelo foi reforçado por uma certa política externa independente e por uma preocupação com os problemas da produtividade nacional, da economia doméstica e da erradicação das desigualdades regionais. Deste modo, o neodesenvolvimentismo mantém o caráter nacionalista e a importância da capacidade do Estado em fomentar e incentivar o crescimento econômico, semelhante ao desenvolvimentismo de fins do século passado. Sua marca diferencial é a redução de desigualdades sociais: distingue-se nesse aspecto do modelo autoritário altamente concentrador da renda e da riqueza, que incentivou o surgimento de grandes grupos empresariais e expandiu o poder aquisitivo de uma parcela ínfima da população, em detrimento de melhores condições de vida de uma enorme massa trabalhadora subempregada.

De fato, o que o neodesenvolvimentismo apresenta é uma espécie de resgate de algumas experiências predecessoras. Experiências da matriz desenvolvimentista iniciada na Era Vargas, de anos atrás e guardadas as devidas proporções, repaginam-se também na atualidade, por meio da promoção estatal, via subsídios, financiamento e organização de formas de proteção social e inclusão social. A política de incentivos à expansão do mercado interno resgata certo papel do Estado no fomento à demanda, numa repaginação do nacionalismo desenvolvimentista predominante na primeira e segunda metades do século passado. Ultimamente, o enfoque sobre os gargalos para destravar o crescimento capitalista demandam à intervenção do Estado mais vigorosa, em grandes obras e projetos de infraestrutura, como de fato o desenvolvimentismo autoritário (e não só ele) buscou fazer.

Por outro lado, a convenção neodesenvolvimentista, preserva os pressupostos institucionalistas e monetaristas ï responsabilidade fiscal, autonomia da autoridade monetária, tripé macroeconômico constituído por câmbio flutuante, superávit primário e metas de inflação - afirmados ao longo período em que prevaleceu certa ortodoxia neoliberal (sobretudo no final do mandato de Fernando Henrique Cardoso) como convenção de política econômica no país. Trata-se de um contexto de experiências prévias que criaram expectativas de agentes produtivos, de mercados financeiros, que passam a pressionar pela permanência de certo cenário e condições a eles favoráveis.

Nesse sentido, contrariamente à complacência do velho desenvolvimentismo com relação à inflação, o neodesenvolvimentismo une-se parcialmente à ortodoxia, na promoção de uma aversão concreta à inflação. No entanto, diferentemente da ortodoxia, o neodesenvolvimentismo acredita que este objetivo não deveria ser pago com o custo de altas 
ilidade macroeconômica decorrente do Consenso de Washington é complementada com um firme compromisso com o pleno emprego e uma distribuição de renda mais progressiva. ñA fé ortodoxa no livre comércio desembaraçado é substituída pela aceitação de controle de capitais, taxas moderadas de endividamento externo e a acumulação de reservas domésticas para aumentar o nível de investimentoò. (BAN, 2013, p. 304, trad. do autor).

Isso se reflete de forma muito clara nos discursos de posse de Lula, tanto em 2003 quanto em 2007. Vejamos:

\begin{abstract}
O Brasil pode e deve ter um projeto de desenvolvimento que seja ao mesmo tempo nacional e universalista, significa, simplesmente, adquirir confiança em nós mesmos, na capacidade de fixar objetivos de curto, médio e longo prazos e de buscar realizálos. O ponto principal do modelo para o qual queremos caminhar é a ampliação da poupança interna e da nossa capacidade própria de investimento, assim como o Brasil necessita valorizar o seu capital humano investindo em conhecimento e tecnologia. (é ) Sobretudo vamos produzir. A riqueza que conta é aquela gerada por nossas próprias mãos, produzida por nossas máquinas, pela nossa inteligência e pelo nosso suor. (LULA DA SILVA, 2003)
\end{abstract}

O Brasil ainda possui sérias travas ao seu crescimento e fragilidades nos seus instrumentos de gestão. Mas nosso País é diferente, para melhor: na estabilidade monetária; na robustez fiscal; na qualidade da sua dívida; no acesso a novos mercados e a novas tecnologias; e na redução da vulnerabilidade externa. Hoje, digo que os verbos acelerar, crescer e incluir vão reger o Brasil nestes próximos quatro anos. (é ) Mas é preciso combinar essa responsabilidade com mudanças de postura e ousadia na criação de novas oportunidades para o País. (é ) É necessário, igualmente, que este crescimento esteja inserido em uma visão estratégica de desenvolvimento que nosso País há muito tempo havia perdido.É preciso uma combinação ampla e equilibrada do investimento público e do investimento privado. Para lograr este equilíbrio, temos de desobstruir os gargalos e de romper as amarras que travam cada um destes setores. Isso significa ampliar e agilizar o investimento público, desonerar e incentivar o investimento privado. Sei que o investimento público não pode, sozinho, garantir o crescimento. Porém, ele é decisivo para estimular e mesmo ordenar o investimento privado. Estas duas colunas, articuladas, são capazes de dar grande impulso a qualquer projeto de crescimento. (é ) Este conjunto de iniciativas significa o reforço das linhas mestras da política macroeconômica, com a redução da taxa real de juros. Tenho claro que nenhum país consegue firmar uma política sólida de crescimento se o custo do capital, ou seja, o juro, for mais alto do que a taxa média de retorno dos negócios. (LULA DA SILVA, 2007)

O primeiro discurso reforça o caráter nacional do desenvolvimento brasileiro: o projeto político abraçado pelo governo Lula espelha o foco no nacional, na medida em que nega a inserção periférica do país no plano internacional. Se historicamente o Brasil, apesar de sua industrialização, inseriu-se no sistema-mundo ainda como um grande exportador de commodities, é no plano nacional que a indústria fortaleceu seu mercado interno. A estratégia discursiva é evidente, e denota o próprio caráter industrialista dessa visão de desenvolvimento. Que, ao mesmo tempo, em sua implementação prática, teve de ceder espaço 
parciais aos setores do agronegócio, eleitos às bancadas do Congresso Nacional, ainda importante setor da pauta de exportação do país, aliado às commodities do extrativismo mineral.

A ampliação da poupança interna e da capacidade de investimento remetem à necessidade de crescimento do Produto Interno Bruto. Contudo, se lermos a íntegra do discurso, não há qualquer menção à manutenção dos pressupostos macroeconômicos de funcionamento da economia, o que só é revelado no discurso de posse após sua reeleição, conforme demonstrado acima. Essa estratégia também demonstra o que significou a eleição majoritária do PT ao Poder Executivo em 2002: uma espécie de rejeição inicial- ou ocultamento da matriz institucionalista que vigeu, sobretudo após a crise do Real em 1999, no governo Fernando Henrique Cardoso.

Isso revela uma espécie de visão pragmática do jogo político atual que, de acordo com o que salientamos no começo deste capítulo, conforma a atuação dos governos. Trata-se, na esteira das experiências historicamente acumuladas, de adoção, ainda que a contragosto, do receituário programático de inserção das economias capitalistas no capitalismo financeiro global, por meio de instrumentos monetaristas que controlem a inflação, destravem as economias domésticas para a entrada de capitais voláteis e garantam o rendimento desses mesmos capitais. Já no começo do governo Lula, os instrumentos monetaristas (institucionalistas) tradicionais de controle da inflação e redução do risco Brasil pelas agências internacionais classificadoras foram lançadas por meio de uma manutenção e mesmo elevação da taxa Selic pelo Banco Central nos meses imediatamente subsequentes à eleição de Lula.

Para entendermos o neodesenvolvimentismo em seu atual estágio, é preciso enxergá-lo no conjunto de relações e processos que se desdobram ao longo do tempo, dentro dos quais contextos mais amplos de uma realidade impactam e dão forma a outras realidades. Isso demonstra que a análise causal é inerente a uma análise sequencial. ñUm exame mais próximo de sequências temporais e processos temporais que se desdobram, em nível doméstico e internacionalò. (THELEN, 1999, p. 390, trad. do autor). A organização política e institucional do Estado brasileiro, e sua maior ou menor participação na esfera econômica e na promoção do desenvolvimento podem ser representados de forma pendular, se observarmos sua conformação atual. Vale dizer, no que se chama neodesenvolvimentismo, as trajetórias e convenções precedentes são revestidos de importante significado, e são aproveitados pelos agentes políticos atuais, conforme seu uso seja conveniente e oportuno (MAHONEY, 2002). A importância dessa avaliação de conveniência e oportunidade é o que marca o 
dentro de margens possíveis, a diferentes classes e setores.

Essa condição faz o fenômeno um conjunto complexo de ações e discursos, que se complementam e ora se contradizem, aproveitando as experiências pregressas. Diante do arranjo institucional presente, seus principais mecanismos de atuação, numa mescla de valores, percepções, exigências e experiências, somadas a um contexto em que, por um lado, não se rompe de vez com o passado (apesar de criticá-lo), mas produz reformas superficiais, que são reforçadas no plano discursivo como de fundo, suficientes para uma distinção programática, polarizada para a disputa eleitoral. Esse reforço discursivo eleitoral implica uma importante linha de manutenção institucional desse modelo.

Diante do complexo processo de modernização e consolidação da economia capitalista no Brasil, pudemos verificar certo aproveitamento de concepções institucionais da relação entre Estado (e seu conjunto) com o mercado, readaptada ao tempo presente. Não se trata aqui de dizer que o neodesenvolvimentismo compreende uma experiência ocupada em reviver ou reorientar o conceito de estado desenvolvimentista de meados do século passado, já que o próprio neodesenvolvimentismo agrega experiências muito distintas entre si, de outros tempos e países. (ARBIX et. MARTIN, 2010)

A trajetória de desenvolvimento do Brasil parece ocupar algum tipo de espaço intermediário, onde talvez seja apropriado falar de categorias híbridas, que ora exibem formas antigas (como o alicerce no tripé macroeconômico, como as subvenções do BNDES, ou mesmo a disposição de erguer grandes obras e projetos) de uso e funcionamento institucional, ora revelam-se completamente novos $\ddot{i}$ especialmente no que diz respeito às transformações mais profundas da implementação de políticas sociais de distribuição de renda, universalização de acesso a educação superior e saúde pública, e inserção de populações pobres no mercado sob a condição de consumidores. A trajetória pregressa é readequada a um contexto de múltiplas exigências, em que se percebe também, sobretudo após as condições contextuais de fortalecimento da democracia e de instrumentos de participação, uma maior vocalização em prol da melhoria de serviços públicos e da organização da capacidade do Estado de gerir recursos, apresentar resultados, contas transparentes e serviços de qualidade à população.

Arbix e Martin, apresentam um diagnóstico importante desse Estado neodesenvolvimentista: seria possível se pensar numa consolidação de um novo tipo de Estado, que assume uma posição que permite intervenções pró-mercado por meio de políticas de competitividade e um papel mais forte em prover serviços sociais e benefícios que estão 
anteriormente excluídas e desassistidas, sem unicamente transferir renda para os pobres. Apontam existir quatro ideias importantes da experiência brasileira em direção à transformação da política econômica dirigista e centrada no Estado. A primeira é que, no neodesenvolvimentismo, o caminho em direção a uma política econômica mais amigável ao mercado se dá com maior intervenção estatal, embora com uma natureza decididamente diferente. A segunda é que não há caminho a uma política democrática e uma economia aberta sem a atuação do Estado, particularmente nos contextos sociais pobres e desiguais do sul. A terceira ideia é que abolir práticas particulares, ferramentas e políticas apoiadas por um quadro estatal não equivale a desmantelar esse próprio quadro. E a quarta é que instituições estatais podem mudar, adaptando-se em torno de novos papéis e políticas (ARBIX et. MARTIN, 2010).

Concordamos parcialmente com esse posicionamento. De fato, a experiência brasileira aponta uma negação do dirigismo estatal da economia, uma adaptação institucional, uma promoção do mercado pela via estatal, uma democratização da política pela inserção, inclusão e promoção de direitos de setores mais pobres da sociedade. Contudo, essa perspectiva apenas reforça certa atuação estratégica do Estado que, como já apontamos, oscila entre uma maior intervenção e um reforço de instituições tipicamente neoliberais. Não se trata de um modelo novo de Estado que vai se autorreforçando ou autoconsolidando, à medida que inclui ou expande setores anteriormente retraídos, mas parte de uma série de ñerros e acertosò do passado para conformar sua atuação no presente. Conforme ressalta Werneck Vianna, o capitalismo brasileiro vive, atualmente, um momento que o conduz a desbordar os limites nacionais: trata-se de um realinhamento dos interesses em disputa, das burguesias nacional e estrangeira. Deste modo, o capitalismo não apenas se escora na força expansiva do mercado interno brasileiro, mas também é reforçado por uma estratégia de Estado consciente dos seus objetivos econômicos e políticos de maximização do poder, em estreita articulação com o grande empresariado. (VIANNA, 2011) Essa atuação ocupa-se de uma quadro referencial desses setores, cujo principal objetivo é garantir a legitimidade e eficácia do funcionamento da economia de mercado, seu maior pressuposto.

1999 marca, portanto, um evento crítico, de ruptura com o modo de se conduzir a política macroeconômica. Ao longo do desenvolvimento econômico brasileiro, o modelo ganha espaço e vai caminhando uma trajetória de autofortalecimento: ele é reforçado pelo conjunto de instituições e de agentes (rentistas internacionais, bancos, grande empresariado industrial) que esperam uma resposta a um momento crítico, e o próprio modelo continua a 
a, tanto como modo de se evitar novas crises quanto garantir que ñaqueles que se beneficiaram dessa resposta, permaneçam dela se beneficiandoò. (PIERSON, 2004, p. 52, trad. do autor). A política econômica torna-se, assim, dependente de uma trajetória prévia, trilhando um caminho de relativa previsibilidade, e hibridizando diferentes conteúdos e matrizes teóricas, conforme sejam convenientes e oportunas em determinado contexto.

\subsection{Conclusão}

Conforme buscamos apresentar, a consolidação do capitalismo no Brasil, ao longo do século XX, foi fruto de um processo de industrialização colocado como um desafio, sobretudo a cargo do Estado. O desenvolvimento econômico, portanto, foi traçado no seio do próprio Estado, como um objetivo a ser alcançado. A matriz desenvolvimentista, construída ao longo de mais de quarenta anos, iniciada em 1930 e finalizada apenas no fim da década de 80, propugnava uma maior participação do Estado no volume de investimentos e promoção da industrialização e desenvolvimento que dela decorreria, ora assumindo empréstimos no exterior, ora realizando grandes obras, ora voltado ao mercado interno. Esse modelo entra em decadência com os choques e pressões internacionais de fins da década de 70, e se desgasta com a crescente financeirização econômica em fins da década de oitenta. Nesse contexto, o discurso monetarista e as instituições típicas de funcionamento neoliberal das economias capitalistas passam a viger no Brasil: a responsabilidade fiscal, o flutuamento de câmbios e juros, a adoção de metas de inflação e de superávit primário são adotados como poderosos instrumentos de estabilização monetária e criação de condições propícias ao investimento e à entrada de capitais voláteis estrangeiros no país. A crise do Real, em 1999, constitui-se deste modo um evento crítico, que incorpora as características novas de mudança da política macroeconômica.

Contudo, a eleição de Lula, o governo petista trouxe à tona uma convenção de desenvolvimento chamada de neodesenvolvimentista, que aproveitou as experiências pregressas, marcando-se por uma trajetória dependente, diante do conjunto de expectativas que recaíam, seja do eleitorado, seja do empresariado e de setores financeiros, no equacionamento entre Estado e mercado nos dias atuais. $\mathrm{O}$ neodesenvolvimentismo, portanto, caracteriza-se como um sistema híbrido, que espelha no Brasil contemporâneo um projeto em disputa, que preza pelo crescimento com inclusão social, mas que se vê também constrangido pelas próprias regras institucionalistas de funcionamento de uma economia de mercado 
Nossa preocupação, diante desse cenário é: qual política de desenvolvimento enquanto direito humano é formulada sob essas condições? Que conceito de desenvolvimento ela adota? E de que forma tal política dissocia-se ou se aproxima, de forma coerente, desse contexto híbrido do neodesenvolvimentismo?

Tentaremos responder a essas e outras questões nos próximos capítulos. 


\section{O DIREITO AO DESENVOLVIMENTO: DO ANSEIO PERIFÉRICO À EXIGÊNCIA RETÓRICA}

\subsection{Introdução}

No capítulo anterior, descrevemos brevemente o processo de modernização capitalista brasileiro, e as condições nas quais a atual opção de política econômica acedeu ao governo federal. Tratamos da formação de uma política oscilante, entre um aspecto mais social, de inclusão e aumento de renda de grupos à margem do crescimento capitalista, e mais liberal, caracterizado pela manutenção, ainda que relativa, de fundamentos monetaristas de estabilidade econômica e observância de compromissos internacionais, em prol de credibilidade internacional e do suposto crescimento econômico dela decorrente.

Nesse aspecto, o quadro que marca os governos de Lula se caracteriza por essa oscilação pragmática, ao sabor da reorganização das forças predominantes no cenário político brasileiro. A constituição desse modelo de inserção, ainda que periférica, de pobres no mercado de consumo e de trabalho, somado ao compromisso resoluto de erradicação da miséria e de maior participação do Estado na indução e elaboração de programas e políticas voltados à universalização de acessos a educação, saúde, previdência social, e a outras políticas sociais sinaliza $\ddot{i}$ ainda que de forma tímida $\ddot{i}$ um projeto perseverante de desenvolvimento.

Não é portanto fortuito nem eventual que esse modelo econômico tenha recebido, pela literatura acadêmica, o nome de neodesenvolvimentismo. Se sua origem, como apontamos, está entrelaçada com o desenvolvimentismo de matriz estruturalista, não menos entrelaçada está com a ideia de desenvolvimento. Os dois mandatos de Lula à frente do Poder Executivo formaram uma síntese contraditória, conforme pontua Singer (2012, p.122), ao ñpromover, simultaneamente, políticas que beneficiam o capital e a inclusão dos mais pobres, com melhora relativa na situação dos trabalhadoresò.

Afinal, qual ideia de desenvolvimento se localiza no cerne do neodesenvolvimentismo? Será possível que, num modelo erguido na mutação tardia do neoliberalismo, o desenvolvimento tenha um papel tão central assim? Essas perguntas são fundamentais ao propósito deste trabalho: afinal, qual a relação entre desenvolvimento 
nos limites mais pragmáticos da política brasileira contemporânea?

Nesse sentido, apresentamos, neste capítulo, o que é desenvolvimento, sob a perspectiva de ideia-força das economias globalizadas no capitalismo, e sua conceituação enquanto direito humano. Para tanto, resgatamos sua afirmação conceitual, a partir das anotações de Amartya Sen e, em seguida, apresentamos brevemente o contexto de seu reconhecimento no plano internacional, para que possamos, no capítulo seguinte, entender o contexto de formulação de políticas de desenvolvimento como direito humano no país, e suas relações com o modelo neodesenvolvimentista vigente.

\subsection{Desenrolar as amarras do passado e do presente: a ideia de desenvolvimento}

A ideia de desenvolvimento está associada a certa percepção vulgar, comum, do tempo histórico da civilização ocidental e capitalista. O tempo histórico situa-se como um terceiro tempo, entre o tempo físico e o tempo filosófico. O tempo físico reflete-se nos movimentos naturais, sucessivos: nascer e pôr do sol, seca e chuva, cheia e vazante, primavera, verão, outono e inverno, dia e noite, sem diferençar passado de presente e de futuro, mas acontecimentos simultâneos daqueles sucessivos, geralmente cíclicos. O tempo filosófico, por sua vez, é o tempo que se define pela apreensão consciente das mudanças, capaz de entender, ainda que diante de eventos que se repetem, o que foi o passado, o que é o presente e criar expectativas sobre o que será o futuro.

Conforme pontua José Carlos Reis, o tempo histórico é um tempo intermediário, construído a partir de duas noções de tempo: o tempo natural da física e o tempo consciente da filosofia. (REIS, 2007). As transformações evidenciadas a partir da segunda metade do século XVIII, com o início da revolução industrial, e a disseminação do ideário racionalista iluminista na porção ocidental da Europa trouxeram à tona uma noção de tempo histórico, à medida em que o capitalismo industrial constituía suas principais bases, e com ele iam se formando as sociedades de massa. Esse tempo histórico se conectava ao tempo de transformação material, evidente, em que diversos fenômenos iam se sucedendo: cidades cresciam, famílias cresciam, tecnologias, produção, riquezas e pobrezas cresciam numericamente. $\mathrm{O}$ racionalismo científico pugnava pela apreensão racional dessas transformações, com o intuito de interpretá-las e classificá-las entre a superação do passado, os desafios do presente e as possibilidades e anseios do futuro. 
materiais da vida social humana, afirmando uma necessidade permanente de ñsuperação do passadoò. Ao passado, vinculava-se a noção de atraso, ao presente, de verdadeiro, e ao futuro, de promissor. Uma das correntes teóricas expoentes dessa noção foi o próprio positivismo comtiano $^{28}$, para a qual o progresso decorreria de uma ciência social, positiva, significada a partir da apreensão de leis imutáveis que regeriam a vida dos seres humanos, a fim de atingir uma significação moral e social maior, positiva. Um estágio em que os demais estágios da existência humana, teológicos ou metafísicos, estivessem superados. Não por acaso, essa corrente surge na primeira metade do século XIX, período em que o capitalismo monopolista iniciava sua empreitada em diversas regiões da África e da Ásia, por meio da expansão imperialista europeia.

Outra perspectiva fundamental do campo científico, surgida também no século XIX, é atribuída a Charles Darwin que, apesar de não ter como objeto de estudo diretamente a sociedade, trouxe a noção de evolucionismo e seleção natural ao cerne do debate acadêmico. Essa perspectiva foi transposta por meio de simplificações comparativas no campo das ciências sociais, com o nome de darwinismo social, que tentava explicar as incongruências e desigualdades observadas a partir do fenômeno da industrialização com base em teorias de seleção, evolução e adaptação ao sistema capitalista industrial de produção. Tal corrente teve Herbert Spencer e Richard Hofstadter como seus principais expoentes.

Não por acaso, no século XIX, a expansão imperialista repetia alguns cânones do colonialismo de séculos atrás, ao se referir a culturas e civilizações em ñatrasoò, e justificava a necessidade de expansão de certa missão civilizadora europeia. Cecil Rhodes, empresário e político britânico que viveu na segunda metade do século XIX, sustentava: ñsomos a primeira raça do mundo, e quanto mais do mundo habitarmos, tanto melhor será para raça humana...Se houver um Deus, creio que Ele gostaria que eu pintasse o mapa da África com as cores britânicasò. (RHODES apud HUBERMAN, 2010, p. 200) Essa percepção de uma cronologia intrínseca ao processo de expansão capitalista, entre atraso e modernização, entre barbárie e civilização, tornou-se um poderoso mecanismo de hierarquização cultural, de dominação de

28 Corrente teórica que contribuiu ao surgimento da sociologia, iniciada na França em meados do século XIX por Auguste Comte, e que representou certa desvalidação de fundamentos metafísicos, exteriores, a uma dada realidade, buscando nas relações existentes entre fatos, acessíveis pela observação, as causas para a realidade. Resumia-se a sete palavras-chaves: real, útil, certo, preciso, relativo, orgânico e simpático. Todas elas expressavam motes de um sistema de valores e certa metodologia para a ação positiva. $\mathrm{O}$ surgimento da corrente está fortemente associado ao contexto de profundas transformações políticas, sociais e econômicas na França no século XIX. 
fortemente associadas à colonização mercantil.

A noção racionalista de tempo histórico acerca da existência humana, em progresso linear e evolucionista, foi sucessivamente confrontada pelo debate acadêmico, que teve nas contribuições metodológicas da história nova ${ }^{29}$ (contraposta à velha história, a história política, de grandes feitos e epopeias, associada a um entendimento de mudanças como superação) e das correntes antropológicas pós-evolucionistas ${ }^{30}$ os principais expoentes. Apesar de apresentar críticas profundas e sistemáticas à ideia de progresso e caminho linear das sociedades, essas correntes não afastaram por completo uma certa confusão, não somente vulgar, mas também presente ainda na atualidade, entre desenvolvimento e progresso ${ }^{31}$.

A crença em um tempo histórico baseado nas ideias de superação do passado, realidade do presente, e expectativa do futuro foi ajustada aos intensos processos de transformação econômica, política e social iniciados com a revolução industrial. Com isso, a civilização que dali nasceu se enxergava como soberana sobre sua cronologia: o presente, real, justificava-se como melhor que o passado, e a incerteza do futuro como possibilidade de ser ainda melhor que o presente. Inventava-se, pela simplificação, a progressividade da existência humana. E com esta maneira de interpretar o processo, a própria percepção da complexidade humana, transitória, via sua importância diminuída. Enfraquecia-se, afinal, o significado mais profundo de desenvolvimento.

29 A história nova encontra seus pioneiros com a geração da Escola dos Annales, surgida na França, na década de sessenta. Um tempo histórico baseado na ideia de forças profundas e longa duração no tempo histórico, e a ideia de velocidade de curto prazo (incapaz de compreender mudanças de fundo) são introduzidos por essa corrente de pensamento, que passa a questionar a própria noção de tempo histórico. O mover histórico é constante, mas há aquilo que permanece ao longo do tempo, sendo lentamente substituído. Nesse sentido, o progresso é questionado por essa corrente, que vê no tempo histórico um delicado e complexo jogo de continuidades e rupturas, singularizadas conforme as exigências próprias de cada contexto social. Para Marc Bloch, só há apenas uma história, ñpura e simples em sua unidade. A história que é toda social, por definiçãoò. (BLOCH apud LE GOFF, 2005, p. 36)

30 Consideramos, nesse sentido, as correntes teóricas da antropologia que questionavam a noção de evolução seletiva e progresso indefinido da escola evolucionista do século XIX. Nessa categoria, o funcionalismo, a escola sociológica francesa e o estruturalismo são importantes exemplos.

31 Uma interessante observação sobre esse ponto pode ser feita a partir da inserção de novas metodologias de pesquisa de opinião ï surveys ï sobre desenvolvimento e bem-estar. Em vez de insistir em critérios objetivos ï e muitas vezes paradigmáticos, espelhados em exemplos exitosos de qualidade de vida de outros países, tidos por desenvolvidos - recentemente algumas pesquisas têm se preocupado com a percepção subjetiva da qualidade de vida e bem-estar econômico das pessoas, o chamado Subjective Well Being (SWB). Como apontam AFSA et. al (2008, p. 15) ñuma vez que os indivíduos são os maiores interessados em seu próprio bem-estar, pode-se considerar que eles são os melhores juízes sobre sua qualidade de vidaò. Curiosamente, o survey consultado utiliza o termo ñprogresso socialò em seu título, reforçando a confusão comum entre desenvolvimento e progresso também no campo especializado. 
noção de progresso e linearidade histórica que tanto se confunde com o termo. Afinal, o que é desenvolvimento? Para a definição de sentido desta palavra, é importante buscarmos suas origens mais remotas. Desenvolvimento, na língua portuguesa, tem sua origem no latim, no encontro de des- (partícula que expressa oposição a algo) e in (com o sentido de para dentro, interior) e volvere (mudar a direção, alterar o rumo, voltar). A matriz, involvere, com o sentido de envolver, envolvido. (CUNHA, 2010) Significa negar a introspecção, negar o movimento para dentro, ou seja, expandir, mover-se de dentro para fora. Com o tempo, a palavra alterou o sentido original de in + volvere, passando a ser usada também para aquilo que envolve, que está à volta de algo, que cerca alguma coisa. Curiosamente, o mesmo radical dá origem a evolução, evoluir. Isso talvez nos aponte algumas razões para a confusão entre a ideia de progresso linear, que segue uma noção evolucionista, e a ideia de desenvolvimento. Desenvolvimento foi uma palavra associada a expansão, a algo de dentro para fora, e, posteriormente, à ideia de retirada de invólucros. Basta um breve olhar sobre outras palavras de origem latina para verificar a permanência dessas ideias: desarollo, em espanhol, que significa retirar aquilo que enrola, que envolve algo, desenvolvemento, em galego, com o mesmo sentido que em português. E, com a complexificação linguística e mutações da língua latina, volvere, volùvi, volùbi, volupi, esta última dando origem, no francês arcaico a voloper e, no italiano, a viluppo, enredo, que descamba em sviluppo, desenvolvimento. (PIANIGIANI, 1907). Do francês arcaico surge também o termo enveloppe na França, indicando o invólucro destinado a comunicações epistolares, e dá origem a developpement, desenvolvimento em francês, e que é apropriado por outras línguas, como o inglês, para formar a palavra development.

Essa breve exposição etimológica nos permite compreender desenvolvimento como um termo associado a duas principais ideias: a de retirada de invólucros, de materiais que aprisionam algo em seu interior, e de um movimento expansivo, extravasante, de algo de dentro para fora. Ambos os significados estão, de uma ou de outra maneira, associados com o próprio movimento de expansão do capitalismo em escala mundial. E expressam os fundamentos de um conceito atual de desenvolvimento, que pretendemos demonstrar a seguir.

Com relação à ideia de movimento expansivo, ela representa a marca mais forte da ascensão ideológica do modo de produção capitalista que se afirmou a partir da revolução industrial iniciada no século XVIII. Era necessário conectar o mundo nesse novo modo de produção, de maneira sistemática, em busca de mercados consumidores, matérias-primas e fontes de riqueza, que estimulassem cada vez mais tal expansão. Extravasar a economia de 
dogenia, externalizando suas relações comerciais com o ocidente tornou-se máxima. Abrir-se, conforme os critérios exigidos pelos países protagonistas da industrialização, a esse processo intenso que a Europa Ocidental vivia na segunda metade do século XIX. Um movimento expansivo, de dentro para fora, do doméstico ao internacional, que também se livrava dos grilhões protecionistas ï ainda que parcialmente ï e exclusivistas do mercantilismo.

A ideologia preponderante que justificava essa expansão era o liberalismo econômico, que teve por princípios básicos assegurar os direitos à propriedade e à liberdade de transações comerciais, e engendrou os Estados burgueses modernos como elementos principais de instrumentalização do poder de ñdeterminar regras que governam relações sociais de produção no interior de sua jurisdição territorialò, e não reconhecer ñnenhuma restrição à sua liberdade legislativa, exceto aquelas que eles mesmos se impõemò (WALLERSTEIN, 2001, p. 44). Apesar de todo esse poder conferido aos Estados modernos, que passavam a definir tais regras em constituições, a necessidade de liberdade de mercado e de direito a realizar transações comerciais sem grandes restrições preponderou por anos, ao menos no plano discursivo. Era indispensável, para essa ideologia, subtrair as amarras e invólucros do Estado mercantil colonialista, e permitir que a livre iniciativa empreendesse abertamente suas atividades.

Em suma, a história da expansão capitalista em nível mundial associa-se a uma necessidade de expansão dos mercados, num processo avassalador centrado na liberalização econômica. Assim:

A liberação da iniciativa privada, o motor que, todos concordam, promoveu o progresso da indústria. Nunca houve um consenso mais esmagador entre economistas ou políticos e administradores inteligentes no que toca à receita para o crescimento de sua época: o liberalismo econômico. As barreiras institucionais que sobreviverem ao livre movimento dos fatores de produção, à livre iniciativa ou a qualquer coisa que concebivelmente pudesse vir a tolher sua operacionalidade lucrativa caíram diante de uma ofensiva mundial (é )Indiscutivelmente, este vasto processo de liberalização encorajou a iniciativa privada, assim como a liberalização do comércio ajudou a expansão econômica, mas não devemos esquecer que grande parte da liberalização formal não era realmente necessária (é ). Por outro lado, a questão do lugar que as mudanças institucionais ou legais têm na proteção ou limitação do desenvolvimento econômico é demasiadamente complexa para a fórmula simplista do século XIX: ñA liberalização cria progresso econômicoò. (HOBSBAWM, 2011, pp. 69-72)

Repaginado anos mais tarde, e sujeito a crises de especulação semelhantes, o liberalismo econômico segue ressignificado, conforme a participação maior ou menor dos Estados nacionais no exercício de seu próprio poder de regulação: de mercados domésticos 
protecionistas. Em suma, o liberalismo econômico e a liberalização dos mercados não deixou de existir, mas sofreu importantes mutações ao longo dos séculos, à medida que se verificava a incapacidade de autorregulação do capital, e certo avanço ou encolhimento da ação estatal. O neoliberalismo, como vimos no capítulo anterior, tem sido uma reedição do liberalismo econômico, ajustado à fase rentista, financeira e especulativa do capitalismo contemporâneo.

A relação entre o significado original de desenvolvimento e a liberalização econômica que justificou a expansão capitalista pode nos ajudar a explicar, parcialmente, por que, ao menos no plano econômico, desenvolvimento e crescimento são conceitos tão intimamente relacionados e, por vezes, confundidos entre si. Em outras palavras, o fato de a economia mundial ter crescido, expandido fortemente e complexificado sua produção, com a expansão capitalista, fez também criar uma espécie de crença, de que tal expansão tenha significado, em essência, desenvolvimento. É necessário que rejeitemos também essa crença, para uma melhor compreensão do que é desenvolvimento.

A expansão material da produção, com a larga complexificação das atividades produtivas e de prestação de serviços, a introdução de novas tecnologias, a estruturação de novos mercados trouxe, sem dúvidas, alguns benefícios mais gerais ao conjunto da população mundial. É inquestionável que a descoberta de vacinas, a invenção de eletrodomésticos, de máquinas produtivas que evitassem acidentes pessoais em fábricas, e os avanços da medicina e da ciência puderam ser disponibilizados a um número não desprezível de pessoas, promovendo seu bem-estar, numa sociedade cada vez mais massificada e interconectada. Tal expansão, acompanhada da complexificação das atividades econômicas, pôde ser apropriada por uma importante fatia da população mundial, que se beneficiou diretamente do crescimento econômico, da inovação tecnológica e da expansão da economia de mercado aos cinco continentes do planeta.

A prosperidade material alargou-se à medida em que novos usos, novos produtos, novos desejos e novos mercados iam sendo incorporados ao quotidiano, acompanhando uma intensa explosão demográfica mundial, garantida por intervenções sanitaristas, melhores condições de produção agrícola (com a mecanização da produção), melhores salários (com as lutas e negociações sindicais), expansão de previdência e assistência social, e acesso a uma medicina cada vez mais rigorosa com seu campo de estudo e com os resultados efetivos na prevenção e erradicação de doenças. A humanidade explodiu em números, e foi progressivamente abandonando a vida agrária e modesta, em direção à ostensividade da vida 

capitalista era o prenúncio de ñuma passagem da pobreza universal para graus variados de prosperidade [que] aconteceu com rapidez no breve espaço de tempo da história da humanidade (é )ò(SACHS, 2011, p. 53).

Entretanto, a prosperidade material, nesse processo de expansão de dentro para fora das economias, foi sendo constatada em graus bastante variados: enquanto uns tornavam-se extremamente prósperos, ricos, outros eram deixados à condição de absoluta indigência, que crescia também em velocidade acentuada. Em continentes inteiros, uma imensa maioria da população crescia e se formava marginalmente, em condições precárias de vida. A expansão do produto material não se demonstrou suficiente para que todos tivessem acesso a uma mesma cesta de produtos e serviços básicos, a fim de garantir continuidade de sua existência. Suas necessidades mais elementares, como comer, vestir, morar sob um teto, saber ler e escrever e gozar de água encanada e rede de coleta e tratamento de esgoto, por exemplo, não eram atendidas de forma automática, como decurso da expansão capitalista.

O crescimento econômico, imensa transformação na produção material, não foi acompanhado de uma universalização do bem-estar, por meio do efetivo acesso a uso de recursos, produtos e serviços por uma enorme parcela da população. O crescimento da pobreza acompanhou o imenso crescimento demográfico e econômico verificado nos séculos XIX e XX, em grande parte do planeta. Segundo estimativas do Programa das Nações Unidas para o Desenvolvimento ï PNUD, cerca de 1,57 bilhão de pessoas vivem atualmente em situação de pobreza multidimensional ${ }^{32}$, o que corresponde a mais que $30 \%$ (trinta porcento) da população dos 104 países objeto de estudo da organização. (PROGRAMA DAS NAÇÕES UNIDAS PARA O DESENVOLVIMENTO, 2013) O crescimento da pobreza, em escala mundial, não apenas coincidiu com o crescimento das economias capitalistas. Demonstrou ser também sua consequência mais imediata: a organização em escala mundial da produção levou a divisões e especializações do trabalho e da produção, a certas zonas desiguais de investimento e especialização tecnológica, a estruturas favoráveis ou desfavoráveis à acumulação de capital. Dividia-se cada vez mais a distância entre o mundo pobre e o mundo rico, em que o primeiro se espelhava em, um dia, tornar-se tão próspero quanto o segundo.

32 Convém de antemão explicar que o conceito de pobreza multidimensional vai além da noção monetarista, simplificada, de pobreza, comumente adotada pelo Banco Mundial para seus estudos e diagnósticos. O Banco Mundial, nessa visão monetarista de pobreza, considera miseráveis aqueles que vivem com menos de dois dólares por dia. A pobreza multidimensional refere-se ao número e intensidade de privações sobrepostas, em saúde, educação e padrões de vida. 
crescimento econômico é condição para a prosperidade, pois seria impossível se falar em mais bens e serviços à disposição da população, acessados e usufruídos por pessoas, atendendo a suas necessidades básicas e a seus desejos nem tão básicos, sem se falar em expansão da oferta desses mesmos produtos e serviços, em correspondência ao crescimento demográfico. Deste modo, a medição material da expansão produtiva passou a ser um importante instrumento, não apenas de confiança em uma economia nacional (de sua capacidade de produzir bens e mercadorias, agregar valor a processos produtivos de transformação e uso de recursos), mas também do crescimento da renda, da demanda de sua população e de populações externas a essa economia, por mais produtos e serviços, de forma mais geral. $\mathrm{O}$ incremento da produção de uma economia, em números absolutos, tornou-se forma para medir a intensidade de sua transformação. Nos dizeres de Mankiw (2009, p. 538), ño produto interno bruto (PIB) de um país mede tanto a renda total auferida na economia quanto o gasto total em bens e serviços nessa economia. O nível do PIB real é uma boa medida do progresso econômico.ò

Mesmo com taxas expressivas de crescimento econômico ao longo dos séculos, e apesar de uma certa percepção de melhoria das condições gerais de vida, os países do sul também chegaram à conclusão de que isso não garantia melhorias estruturais e profundas de suas condições históricas de pobreza e marginalização social. Desigualdade, por um lado, e crescimento econômico enquanto condição de ampliação dos acessos, por outro, eram portanto constatações decorrentes do processo expansivo da produção capitalista.

A distribuição de recursos, a superação da pobreza multidimensional, a melhoria das condições de vida das pessoas em geral dependia de ações políticas coordenadas pelos Estados, e não somente de expressivas taxas de crescimento econômico, que poderiam beneficiar poucos. Ainda que o crescimento seja importante, pela constatação óbvia da impossibilidade de se distribuir o que ainda não foi produzido a não ser por meio de ganhos gerais concretos ou por meio de empréstimos, o crescimento econômico não se confundia com desenvolvimento. Desenvolvimento passou a estar associado a certas mudanças qualitativas, profundas, nos quais bem-estar e melhoria de condições gerais de vida estão fortemente entrelaçadas. Desta forma, o conceito de desenvolvimento encontra-se muito além da mera complexificação de atividades econômicas, ou de simples incremento da produção.

Chegamos ao segundo aspecto do conceito de desenvolvimento: a retirada de invólucros, de entraves, de materiais que aprisionam algo em seu interior. Do ponto de vista 
traduzida na ideologia do liberalismo econômico. Todavia, como apresentamos, a expansão econômica pela via da liberalização foi também acompanhada de forte aumento da pobreza e concentração de riquezas. A liberdade como máxima da economia tornou-se o próprio veneno do processo, na medida em que produziu desigualdades imensas, não foi tornada igualmente universal, e deixou um saldo de milhões de pessoas à margem desse processo, sem a liberdade mais elementar do sistema: poder escolher ñtilizar recursos econômicos com propósitos de consumo, produção ou trocaò. (SEN, 2009, p. 55) O sistema capitalista liberal processou, assim, sua própria contradição.

Nesse sentido, uma definição interessante de desenvolvimento econômico foi proposta por Celso Furtado. O economista paraibano traduziu a ideia de desenvolvimento na junção entre crescimento econômico e benefício geral das pessoas. Tal benefício geral é medido por meio de eficiência. Uma economia ascendente precisa disponibilizar com eficiência e em benefício do maior número de pessoas quanto possível o resultado de seu incremento produtivo. Quanto mais pessoas puderem fazer uso de produtos e serviços os mais distintos, maior será a satisfação de suas necessidades e desejos, e tanto maior será o desenvolvimento de determinado grupo. Assim:

A ideia corrente de desenvolvimento econômico refere-se a um processo de transformação $i ̈$ no sentido morfogenético: adoção de formas que não são um simples desdobramento das preexistentes ï que engloba o conjunto de uma sociedade. Essa transformação resulta da adoção de métodos produtivos mais eficazes e se manifesta em aumento do fluxo de bens e serviços finais à disposição da coletividade. Assim, a ideia de desenvolvimento liga-se, causalmente, ao conceito de eficiência e, por outro, à de abundância ou riqueza. Às formas mais racionais de comportamento corresponde uma satisfação mais plena das necessidades humanas. (FURTADO:,2008, p. 130)

Ora, a abundância ou riqueza, de fato, é expressa pelo crescimento da produção material: quanto mais bens, produtos, mercadorias, matérias-primas, e ativos existirem, quanto mais abundantes forem, maior a chance de essa economia explorá-los e transacionálos, e apresentar crescimento econômico com algum vigor. Mas a ideia de eficiência somente pode ser concebida em economias capazes de distribuir corretamente tais riquezas: quanto maior for o total de pessoas a gozar ou dispor de bens e serviços, reduzindo as perdas de uma grande maioria em detrimento da concentração de riqueza de uma minoria, mais eficiente será a disponibilização de produtos e serviços finais à coletividade, a fim de se garantir que o maior número possível de pessoas perceba e usufrua da abundância. A ideia de desenvolvimento, para Celso Furtado está assim fortemente associada a um aspecto 
ssoas usufruindo dos muitos serviços e bens gerados), e a um aspecto distributivo, de maior eficiência no uso de recursos (pessoas com suas necessidades mais plenamente satisfeitas).

Verificamos, nesse breve quadro conceitual, que o desenvolvimento não se confunde com crescimento econômico, pois se alia a certa noção qualitativa: a satisfação das necessidades humanas não está reduzida à simples expansão material da produção, mas a uma correta e eficiente distribuição dessa produção no sentido de satisfazer necessidades. Conforme pontuamos nesse mesmo quadro, o aspecto de expansão, de movimento expansivo, de dentro para fora do conceito de desenvolvimento transformou o planeta local em planeta global, conectado sistematicamente em um modo de produção com o objetivo de liberar entraves entre uma região e outra, garantindo sua expansão. A liberalização, a derrubada de entraves para o exercício das atividades comerciais e produtivas, por outro lado, estava no cerne do processo de expansão capitalista.

Sob essas condições, a noção de retirada de invólucros do desenvolvimento teve de ser redimensionada: não poderia reduzir-se à simples liberdade propagada pelo liberalismo econômico, mas devia voltar sua atenção a uma complexa condição humana: a liberdade em seu mais profundo sentido.

A união entre retirada de invólucros e movimento expansivo como conceito de desenvolvimento requer portanto que pensemos tal conceito tanto sob o aspecto da expansão de liberdades (em seu mais profundo e complexo sentido), quanto na derrubada de entraves que inviabilizem o pleno exercício dessas liberdade.

Assim, além de uma perspectiva exclusivamente alicerçada no consumo e uso de bens, serviços e mercadorias, a liberdade deveria ser traduzida numa conquista complexa, em muitos outros campos da vida social. Esta teoria foi formulada por Amartya Sen, economista e filósofo indiano, que equiparou desenvolvimento à liberdade, em sua mais famosa obra, originalmente publicada em 1999. É essa teoria que adotamos neste trabalho, e que intentamos explicitar a seguir.

\subsection{Desenvolvimento como liberdade: uma tarefa de conceituação.}

Uma das contribuições mais importantes da obra de Amartya Sen foi encarar que o crescimento do Produto Interno Bruto, o aumento de rendas pessoais, a industrialização, o 
ão das sociedades representam meios de se expandir a liberdades das pessoas (SEN, 2009, p. 17). Não se trata de confundi-los com desenvolvimento, tampouco de classificá-los como consequência do desenvolvimento, mas percursos possíveis dessa trajetória.

Contudo, a expansão de liberdades (o desenvolvimento, nessa acepção de desenvolvimento como liberdade) depende também de outras influências. Sen admite que o crescimento econômico é algo importante para o exercício das liberdades, uma vez que é capaz de gerar oportunidades (SEN, 2009). Mas o exercício da liberdade não se restringe a essa condição. A carência de serviços públicos de assistência social, educação, instituições para manutenção da paz e ausência de participação política podem levar a severas violações da liberdade, e impedir o processo de desenvolvimento. A expansão das liberdades é, para Sen, portanto, a finalidade do desenvolvimento.

A teoria de desenvolvimento como liberdade advoga, de certo ponto de vista liberal, o caráter abrangente e complexo do processo de desenvolvimento. Não se trata de uma visão puramente econômica de desenvolvimento, mas de uma visão que atravessa questões sociais e políticas. Sob esse aspecto, Sen (2009, p. 23) ressalta:

(é ) faz diferença adotar a visão do desenvolvimento como um processo integrado de expansão de liberdades substantivas interligadas. É essa visão que apresentamos, esmiuçamos e utilizamos neste livro para investigar o processo de desenvolvimento integrando considerações econômicas, sociais e políticas. Uma abordagem ampla desse tipo permite a apreciação simultânea dos papéis vitais, no processo de desenvolvimento, de muitas instituições diferentes.

Para que possamos avançar em nossa análise, é preciso antes de tudo deixar claro que, ao apontarmos, no Capítulo I, a trajetória da modernização capitalista brasileira ao longo dos séculos XX e XXI, nossa intenção está longe de considerar o desenvolvimento em seu aspecto puramente econômico. Trata-se muito mais de apresentar as condições estruturantes, de formação de um novo modelo de Estado, com capacidades ampliadas, que guarda relação profunda de sua atuação com o passado, e que aposta suas fichas numa proposta de desenvolvimento para o presente. Veremos com mais atenção a formação e limites dessa proposta, sob a perspectiva dos direitos humanos, no próximo capítulo.

Feita essa ressalva, uma interessante e próxima definição de desenvolvimento à apresentada por Sen é concebida por Ignacy Sachs, que afirma que o desenvolvimento tem a pretensão de tornar cada ser humano apto a exercer suas potencialidades, talentos e imaginação, em busca de autorrealização e felicidade, através de ações individuais e coletivas, 
produtivas. Afirma ainda que a boa sociedade é aquela que maximiza essas oportunidades, enquanto cria, de forma simultânea, um ambiente de convivência e condições para produção de meios de existência que supram necessidades materiais básicas da vida. (SACHS, 2008). A perspectiva apresentada por Sachs encara o desenvolvimento como o exercício livre das potencialidades humanas, e ocupa-se de um projeto de ñboa sociedadeò. A liberdade tenderia, ao menos de modo abstrato, a garantir maior eficiência no exercício de ações individuais ou coletivas: sem restrições que tolham escolhas e ações voltadas a viabilizar o exercício das potencialidades e talentos de cada um.

É evidente que tais teorias propugnam o desenvolvimento com certo nível de abstração. A liberdade de que se ocupa Amartya Sen não se contenta com apenas a afirmação retórica de liberdades individuais, mas preocupa-se com afastar completamente as privações objetivas que impedem uma vida de qualidade. Preocupa-se com ños processos que permitem liberdade de ações e decisões como as oportunidades reais que as pessoas têm, dadas as suas circunstâncias pessoais e sociaisò. (SEN, 2009, p. 31). Oportunidades reais são aquelas que vão além da mera afirmação retórica de liberdade universal, que de fato se apresentam como condições concretas, para uma vida de qualidade. Não morrer de desnutrição infantil ou cólera, não morrer por não saber ler a bula de um medicamento, poder acessar comidas limpas e variadas para se alimentar, poder acessar formas de transporte para acessar a educação e a instrução, poder acessar a educação para poder acessar trabalhos de natureza mais complexa, que por sua vez permitam acessar outros bens e serviços de que se necessite ou se deseje.

A teoria seniana espelha, deste modo, uma preocupação com acessos sociais $̈$ ï os mais distintos, em que as pessoas possam de fato exercer suas escolhas e potencializar suas vidas: oportunidades produzem escolhas, e escolhas são feitas mediante acessos, nessa acepção.

O exercício de capacidades, desta maneira, depende de liberdades negativas, isto é, da ausência intervenções ou ingerências alheias na vida das pessoas que as impeçam de exercerem suas potencialidades ou impeçam sua ação positiva em seu ambiente; e depende também de liberdades positivas: afirmações concretas, traduzidas em condições de acesso, que lhes permitam realizar escolhas. As capacidades são, assim, o conjunto de combinações alternativas do que Sen chama de funcionamentos, que por seu turno são as várias coisas que uma pessoa pode considerar como valiosas (fazer ou ter). É claro que os funcionamentos variam de pessoa para pessoa, e de contexto para contexto: calefação pode ser um funcionamento essencial à sobrevivência de um habitante da Escandinávia, mas 
elementares e universalmente necessárias, como alimentação, ou se ver livre de doenças evitáveis, ou podem variar de pessoa para pessoa. (SEN, 2009) As capacidades são as combinações alternativas de funcionamentos: quanto mais se puder escolher entre um funcionamento ou outro, e quanto maior o número de alternativas e escolhas, maior o estado de liberdade dessa pessoa. Essas condições são indispensáveis a uma economia do bem-estar, cujo principal objetivo é reverter-se em bem-estar pessoal e coletivo.

Portanto, três conceitos são apresentados por Sen em sua teoria da economia do bemestar: liberdade, capacidade e funcionamentos.

A capacidade é principalmente um reflexo da liberdade para realizar funcionamentos valiosos. Ela se concentra diretamente sobre a liberdade como tal e não sobre os meios para realizar a liberdade, e identifica as alternativas reais que temos. Neste sentido, ela pode ser lida como um reflexo da liberdade substantiva. Na medida em que os funcionamentos são constitutivos do bem-estar, a capacidade representa a liberdade de uma pessoa para realizar bem-estar. (SEN, 2012, p. 89)

Ao dissecar esses conceitos, Sen preocupa-se fundamentalmente com uma aproximação entre ética e economia. Claramente influenciada pelo utilitarismo ${ }^{33}$, sua teoria tenta no entanto se afastar da concepção meramente utilitarista de economia, resultante da combinação entre welfarismo (ñondadeo ${ }^{34}$ de estado de coisas resultante de informações sobre utilidades relativas a tal estado), ranking pela soma (informações sobre utilidades relativas a qualquer estado consideram apenas o somatório de todas as utilidades desse estado) e consequencialismo (toda escolha é determinada pela ñondadeò de estados de coisas decorrentes). (SEN, 2012).

Ou seja, a crítica de Sen, em suma, é dirigida ao modelo welfarista de economia, que representa uma forte limitação de base de informações, na medida em que se importa apenas com as utilidades (o grau de satisfação de carências e desejos), que passam a ser o único

33 A escola utilitarista surgiu na Inglaterra em finais do século XVIII e início do século XIX, por meio da obra de Jeremy Bentham e John Stuart Mill. Com fundamento no ñgreatest happiness principleò, ou princípio da maior felicidade, o utilitarismo na economia advoga que o comportamento de agentes econômicos tentem a ser maximizadores de uma determinada função utilidade. Isto é, a produção e a circulação de bens numa economia estariam atrelados ao princípio de utilidade, de satisfação de necessidades e desejos para obtenção de um prazer, uma realização, ou em última análise, de felicidade. Assim, admite que, se uma mudança for vantajosa para cada pessoa, tende a ser uma mudança vantajosa para toda a sociedade. Tal tendência de maximização das utilidades levaria ao chamado teorema da optimalidade de Pareto, em que seria impossível aumentar a utilidade de uma pessoa sem reduzir a utilidade de outra pessoa. Seria um estágio máximo de eficiência econômica, ou máximo de bem-estar, em que utilidades, bens e serviços estariam eficientemente distribuídos entre as pessoas, satisfazendo seus desejos de forma satisfatória ï senão plena ï e no maior número possível.

34 Wellness, no texto original. Seria uma espécie de estado de coisas ou situações benéficas, favoráveis às pessoas. 
econômica, partindo de pressupostos universalmente válidos: algo como um padrão de bens, acessos e serviços universal e igualmente extensíveis a qualquer pessoa, como forma de alcance de um objetivo, um estado coletivo de bem-estar desejável a determinada sociedade.

Amartya Sen considera eminentemente questionável a perspectiva welfarista, para a qual parece existir algo como um consenso geral sobre a utilidade de coisas revertida em bemestar. Tal consenso tende a excluir diferenças informacionais (de condições pessoais subjetivas, locais, entre população economicamente ativa e inativa, entre velhos e crianças, p. ex.). O poder dessas exclusões de informações combinadas pode ser percebido no exercício de agregação dos interesses em conflito entre ricos e pobres. Tais exclusões tornam, com efeito, impossível priorizar o interesse dos pobres, já que somente utilidades e desejos, e não condições distintas, são o foco do welfarismo. Os pobres, nessa acepção, não podem ser distinguíveis dos ricos $\ddot{i}$ seja em termos de utilidade, seja em termos de renda ou outra informação sobre utilidades irrelevante. Há muitas formas de evitar o impasse: abrir mão do welfarismo é uma, fazer uso de informações mais ostensivas é outra. (SEN, 1982)

Para o autor, algumas outras variáveis explicariam uma economia do bem-estar para além do utilitarismo. Uma dessas variáveis seriam as comparações interpessoais de utilidade, ou seja, o juízo de valor que as pessoas fazem quanto à utilidade de determinado bem ou serviço, comparativamente a outras pessoas e situações. Sen admite que a realização de bemestar, assim, exige atenção às ñvárias coisas importantes que uma pessoa consegue fazer ou serò (SEN, 2012, p. 79). Ou seja, a pessoa, em sua condição de agente, atribui valor às coisas não somente através de um critério racional, mas muitas vezes em comparação a certas pessoas ou situações, e ordenando decisões e prioridades em detrimento de outras escolhas. Uma avaliação não apenas global e espontânea, mas também específica e conjuntural pode ser consistente tanto para uma decisão pessoal quanto coletiva.

Essa perspectiva é importante para que possamos compreender a economia do bemestar, proposta por Sen: a vantagem pode ser medida pelos instrumentos disponíveis para que uma pessoa avalie e faça aquilo que melhor pode ser traduzido como satisfatório, sem perder de vista a ordenação completa (e transitiva) acerca da pluralidade de bens. Em outras palavras, não basta apenas que um conjunto homogêneo de funcionamentos esteja garantido às pessoas, mas que as pessoas possam de fato compreender e avaliar qual funcionamento é melhor aproveitado e revertido em seu benefício e de sua condição transitória ou contextual. Citemos um exemplo: um adolescente negro, morador da periferia de uma grande cidade 
que sua casa não desabe por motivos de deslizamentos decorrentes de chuvas, que qualquer outro acesso (seja a ensino gratuito, seja a políticas de igualdade racial, seja a oportunidades reais de trabalho e capacitação profissional).

Por isso, há que se considerar a avaliação como um processo essencial às escolhas dos sujeitos (comparativamente a outros sujeitos, mas também a outros funcionamentos disponíveis ou pretendidos). Para o exemplo citado, a segurança protetora da defesa civil, num dado momento de risco aparente de outras habitações vizinhas em decorrência de chuvas, por exemplo, e a garantia de continuidade do acesso a moradia própria, são mais relevantes que outros funcionamentos. Essa ordem de prioridades é feita diariamente em nossas vidas, nas escolhas pessoais que nos movem, ou nas ações e escolhas de outros que nos possam ser úteis.

Retomaremos, no capítulo seguinte, a teoria proposta por Sen, aproximando-a do contexto recente de fortalecimento das capacidades estatais no Brasil, de erradicação da pobreza extrema, e avaliaremos parcialmente o modelo de desenvolvimento em curso.

Por ora, é necessário indagar: se a teoria de Sen se afasta do welfarismo e de seu critério de desconsideração de utilidades e vantagens pessoais, em detrimento de certa utilidade universalista, será possível entender um certo relativismo metodológico dessa teoria, que tenderia a enfraquecer o discurso de universalidade de acessos? Nestes termos, quão compatível seria a teoria do desenvolvimento como liberdade com a ideia de desenvolvimento enquanto direito humano?

Preliminarmente, é preciso lembrar que, para a teoria de desenvolvimento como liberdade, a avaliação subjetiva e intersubjetiva é essencial. Trata-se de priorizar acessos e capacidades específicos a agentes determinados, diante de certas informações disponíveis. A avaliação das condições e limitações específicas é uma ferramenta essencial não para o fim de realização de um bem-estar abstrata ou genericamente considerado, mas para a garantia do exercício da liberdade de alcançar o bem-estar concreto e mais adequado a cada condição. Trata-se de uma visão que não menospreza a importância do agente na condução de sua melhor escolha, revertida no resultado mais eficaz de satisfação de seu bem-estar. Noutras palavras, uma liberdade instrumental para o alcance do bem-estar. Assim: 
oferta a todos da oportunidade de levar uma vida minimamente essita ser unida à insistência de que todos façam uso de todas as oportunidades que o Estado oferece. Por exemplo, a garantia de todos do direito de dispor de uma quantidade adequada de alimento não necessita ser unida a uma proibição estatal do jejum. (SEN,2013, p. 322)

Não se trata de um liberalismo tradicional, que traduz liberdade sobretudo como ausência ou mínimo possível de ingerência estatal na vida dos cidadãos, mas de liberdade em seu aspecto mais substantivo: o de exercício amplo e efetivo de diferentes escolhas.

Nesse sentido, mesmo que a avaliação pessoal priorize o acesso a diferentes funcionamentos de acordo com as situações pessoais, Sen não estabelece um elogio irrestrito do relativismo liberal. Admite que a garantia do exercício de direitos está fortemente associada ao esforço estatal, à ação coordenada que assegure liberdades nos aspectos mais variados quanto necessários. Tais liberdades são o que Sen classifica como liberdades substantivas.

Liberdades substantivas são fundamentais ao processo de desenvolvimento. Significa dizer que, à medida que as pessoas se sentem cada vez mais livres para realizar as atividades de que gostam, sem obstruções ou constrangimentos que as impeçam de fazer o que valorizam, maior a chance de obterem resultados valiosos. Para isto, a noção de iniciativa individual e eficácia social são fundamentais: quanto mais iniciativa tiverem as pessoas, individualmente, mais eficazes serão suas ações, em busca de cuidar de si mesmas e do mundo que as cerca. (SEN, 2009) Algo como uma felicidade intrínseca a esse status libertatis faz parte da linha argumentativa de Sen, que considera, ciente dos riscos de sua simplificação explicativa, o aspecto da condição de agente do indivíduo. O agente, portanto, atua de acordo com seus próprios valores, membro do público e ator em ações em diversas transações econômicas, sociais e políticas.

De forma simplificada, poderíamos traduzir os principais conceitos da teoria seniana do desenvolvimento como liberdade conforme o quadro conceitual abaixo: 


\section{II0CTuatu.}

\begin{tabular}{|c|l|}
\hline Conceito & \multicolumn{1}{|c|}{ Definição } \\
\hline Funcionamentos & $\begin{array}{l}\text { Estados, atividades e coisas que as pessoas } \\
\text { valorizam em suas vidas }\end{array}$ \\
\hline Capacidades & $\begin{array}{l}\text { Combinaçães múltiplas de funcionamentos } \\
\text { atividades e modos de ser que uma pessoa } \\
\text { pode alcançar, que reflete a liberdade pessoal } \\
\text { de escolher entre vários modos de viver. }\end{array}$ \\
\hline Liberdades substantivas & $\begin{array}{l}\text { Processos e oportunidades constitutivos (senão } \\
\text { indispensáveis) ao exercício de outras } \\
\text { liberdades, como evitar a fome, a subnutrição, } \\
\text { ter liberdade de expressão } \\
\text { Processos e oportunidades obtidos por meio de } \\
\text { direitos e funcionamentos disponíveis para } \\
\text { expansão da liberdade humana em geral, que } \\
\text { podem variar em grau de obtenção e } \\
\text { reconhecimento: participação política, } \\
\text { oportunidades sociais e facilidades econômicas }\end{array}$ \\
\hline
\end{tabular}

Há uma linha fundamental na teoria do desenvolvimento como liberdade. Trata-se de certo equilíbrio do nível de responsabilidades sobre a qualidade de vida das pessoas: nem tanto ao Estado, nem exclusivamente ao indivíduo. Assumindo o pressuposto de que iniciativa, esforços pessoais e respeito próprio são elementos importantes para que as pessoas zelem por seus próprios interesses e problemas, Sen também admite que sem um contexto de circunstâncias sociais e ambientais favoráveis, em certa medida de responsabilidade do poder público, é impossível uma vida de qualidade. Esse argumento é central em sua obra (SEN, 2009, pp. 321-322):

Qualquer afirmação de responsabilidade social que substitua a responsabilidade individual só pode ser, em graus variados, contraproducente. Não existe substituto para a responsabilidade individual. $\mathrm{O}$ alcance e a plausibilidade de um apoio exclusivo na responsabilidade pessoal podem ser mais bem discutidos somente depois de seu papel essencial ter sido reconhecido. Contudo, as liberdades substantivas que desfrutamos para exercer nossas responsabilidades são extremamente dependentes das circunstâncias pessoais, sociais e ambientais. (é ) Assim, o argumento do apoio social para expandir a liberdade das pessoas pode ser 

substantiva e a capacidade para realizar alguma coisa, a pessoa não pode ser responsável por fazê-la. Mas ter efetivamente a liberdade e a capacidade para fazer alguma coisa impõe à pessoa o dever de refletir sobre fazê-la ou não, e isso envolve responsabilidade individual. Nesse sentido, a liberdade é necessária e suficiente para a responsabilidade.

Tais liberdades substantivas (liberdades essenciais que garantem o exercício de outras liberdades individuais) tendem a se reverter em benefícios para além do indivíduo. O desenho das liberdades individuais, nesse sentido, é traçado junto ao desenho institucional de políticas públicas. Isto é, uma política é eficaz na medida em que visa atender os interesses de um público-alvo que, diante do atendimento desses interesses, é capaz de estimular por sua vez outras pessoas a agirem e influenciarem suas vidas e contextos de forma positiva. Por isso mesmo, Sen atenta-se para ña expansão das capacidades das pessoas de levar o tipo de vida que valorizam [é ], que podem ser aumentadas pela política pública, mas também, por outro lado, a direção da política pública pode ser influenciada pelo uso das capacidades participativas do povoò. (SEN: 2009, p. 32).

\subsection{Direitos humanos econômicos e sociais: desenvolvimento como imperativo, retórica ou efetividade?}

O afastamento da ética universalista do welfarismo, de utilidades universais, resulta em certa relativização do conceito de desenvolvimento, conforme visto na seção anterior. Como será possível, então, aproximar o conceito de desenvolvimento ao conceito de direitos humanos, geralmente associado a um universalismo ético, que prega a existência de direitos extensíveis de forma objetiva a todo e qualquer ser humano? Como aproximar o desenvolvimento, que depende da avaliação circunstancial de bem-estar, transitiva, à ideia de que existam direitos universalmente reconhecidos, atribuídos a todo e qualquer ser humano? Algumas questões, formuladas por Amartya Sen em sua obra A ideia de justiça, podem nos ser bastante úteis para estendermos e aprofundarmos essas indagações: afinal, seriam os direitos humanos uma crença geral e atraente, uma espécie de retórica com alguma eficácia política? E mais: os direitos humanos existem? Sua existência decorre simplesmente da condição humana das pessoas? 
travadas nas sociedades ocidentais, e advém do reconhecimento que tais direitos passaram a ter, sobretudo a partir da segunda metade do século XVIII, com as revoluções liberais burguesas iluministas e as declarações que manifestavam certos direitos inalienáveis, como a vida, a liberdade de opinião, expressão e crença, o direito de eleger representantes e participar da vida política, o direito a um processo legal que ofereça recursos de defesa, e outros tantos. A partir de então, os processos de demandas sociais, por meio de reivindicações e lutas organizadas se complexificaram, trazendo à tona novas dinâmicas, novas pretensões e sujeitos de direito e, com isto, outros muitos direitos, reconhecidos como direitos humanos por meio de declarações e compromissos além das fronteiras dos estados nacionais.

Tais declarações, documentos formais que consubstanciam um protocolo de intenções escritas, como a Declaração Universal dos Direitos Humanos, de 1948, reconhecem a existência de direitos, tratando-se, portanto, de projetos esperados: de algo que deve ser feito. Tais declarações exigem o reconhecimento, por todas as pessoas, de que algo precisa ser feito para concretizar liberdades reconhecidas através desses direitos. Esse aspecto formal da existência dos direitos humanos é alvo de críticas, que geralmente enxergam nas declarações um belo protocolo de intenções, infelizmente não observado com a devida efetividade e sem realização concreta e efetiva em muitos contextos.

Amartya Sen rebate tais críticas, ao afirmar que os direitos humanos não pretendem ser o que já são os direitos previstos em leis, estatutos ou costumes, dotados de coercitividade para que tenham efetivo cumprimento, e correspondência imediata de dever de um agente (ou destinatário específico). Os direitos humanos são, em essência, revestidos de conteúdo ético e, além de servirem como certa dose de inspiração para a elaboração de leis nacionais, necessitam de adesão racional ampla e constante, mediante o reconhecimento de que é preciso fazer algo para concretizar as liberdades por eles proclamadas.

No que diz respeito ao aspecto das declarações, e também da defesa de direitos humanos, o autor ressalta:

As declarações éticas, com distinto conteúdo político e pertencentes a uma declaração de direitos humanos podem provir de pessoas ou instituições, e ser apresentadas como comentários individuais ou como enunciados sociais. Também podem ser feitas, com bastante destaque, por grupos específico encarregados de examinar essas questões; (...) As vias e as maneiras de defender a ética dos direitos humanos não precisam se restringir à elaboração de novas leis (embora muitas vezes a legislação possa se mostrar o caminho correto para se proceder); por exemplo, o monitoramento social e outras formas de apoio ativista, oferecidas por organizações como o Human Rights Watch, a Anistia Internacional, a Oxfam, os Médicos sem Fronteiras, Save the Children a Cruz Vermelha e a Action Aid (citando tipos muito 
Gs), podem contribuir para ampliar o alcance concreto dos direitos ecidos. Em muitos contextos, de fato, não há nenhum envolvimento na legislação. (SEN, 2013, pp. 394; 399- 400)

Deste modo, Sen admite em sua teoria que o conteúdo ético dos direitos humanos serve de motivação para diversas mobilizações, seja a de elaboração e aplicação de leis com conteúdo de direitos humanos, pelo Estado, seja a mobilização de pessoas, da sociedade civil organizada contra violações de direitos, em busca de conferir alcance concreto a prescrições sociais (SEN, 2013). Seu conteúdo não diz respeito a um único e determinado destinatário, mas serve de instrumento em prol da mobilização que visa assegurar liberdades fundamentais, e garantir às pessoas o exercício de uma vida com dignidade. Tratam-se de direitos que fornecem razões para que as pessoas lhes concedam séria atenção. Por isso mesmo, são direitos sujeitos a amplo debate público, com importância social suficiente para que, na esfera pública, possam ser debatidos pelo crivo da opinião pública.

As prescrições deontológicas dos direitos humanos constituem uma certa exigência ética, que se pretende universal: oferecem instrumentos razoáveis (submetidos ao crivo do debate em arenas públicas) para se admitir que, se uma pessoa (ou várias) tem condições de fazer algo para impedir a violação de um direito, ela tem boa razão para fazê-lo. A concretude e realização dos direitos humanos decorrem da combinação entre a avaliação subjetiva, e a prescrição ética que de fato mobiliza alguém a fazer algo por outra pessoa.

Portanto, a violação, ou a não realização de liberdades subjacentes a direitos significativos, a direitos humanos, compreende uma realização social geral ruim, indesejável. A avaliação subjetiva, das condições de violações de direitos humanos, depende de certo exame do que seria possível fazer racionalmente para ajudar a realização de uma liberdade de uma outra pessoa. Nesse sentido, Sen reafirma a importância da avaliação como instrumento de ação.

Para que fique mais claro, tomemos um exemplo: certo número de crianças morrendo de fome e inanição numa aldeia no sul da Etiópia. Para aquelas pessoas que ali vivem, a fome não é um acaso, mas ocorre com certa frequência, por problemas de abastecimento, plantio, estoques e extrema pobreza da população local. Nessas condições, certos direitos humanos são sucessivamente violados: direito a uma alimentação adequada, direito à vida, direito à saúde. Por mais que as autoridades locais e os habitantes daquela aldeia conheçam o problema frequente que ali se apresenta, sua capacidade de ação e mobilização contra tais violações de direitos é muito baixa: faltam recursos para investir em técnicas de plantio e manejo 
pplementação de uma política adequada de subsídios à agricultura familiar, falta uma saída para escoamento de produção, faltam estradas vicinais, faltam programas de estocagem de alimentos... Enfim, a carência é grande. A avaliação dessas pessoas sobre tal situação pode de fato ser no sentido de que ali há graves violações de direitos humanos básicos.

Qual seria a ação objetivamente esperável dessas pessoas, para reverter esse quadro, evidentemente grave? Podemos tentar indicar algumas ações que, pontuais, ou isoladas, não serão mais que esforços de baixo impacto, como a distribuição de alimentos. Por outro lado, governos de países ricos, ou organizações não governamentais com recursos podem, além de distribuir alimentos e fomentar investimentos regionais, estimular políticas em parceria com o governo nacional etíope que, por seu turno, podem fazer a diferença concreta contra tais violações. A avaliação depende, assim, de enxergar as condições em que o agente (e aquele que sofre as violações de direitos humanos) se encontra, com o objetivo de oferecer a melhor resposta a um determinado problema. Em ambos os casos, o imperativo ético das declarações de direitos humanos serve como instrumento de identificação de violações.

Não há deste modo que se identificar automaticamente ações prontas e acima de quaisquer exigências: os direitos humanos compreendem uma exigência ética universal, mas não uma única exigência, preestabelecida. Sua concretude depende de avaliação correta e precisa de determinados problemas, e da escolha de meios e instrumentos igualmente corretos para solucioná-los.

A discussão proposta por Sen também aborda o problema dos direitos sociais e econômicos, objeto de nosso estudo: o direito ao desenvolvimento é um direito que se encontra nessa categoria. Direitos sociais e econômicos são os direitos decorrentes do que o autor considera ser uma revolução dos direitos (SEN, 2013): alçados à condição de direitos humanos, além dos direitos civis e políticos ï tradicionalmente relacionados a liberdades fundamentais (como expressão, direito a eleger representantes e ser eleito, liberdade de crença, etc.), os direitos econômicos e sociais englobariam, por exemplo, o direito ao trabalho, à educação, à proteção contra o desemprego e pobreza, o direito à sindicalização e a remuneração justa e razoável.

Os direitos econômicos e sociais, ao alcançarem o status de direitos humanos, reconhecem em nível global a existência da pobreza econômica e da desigualdade sistêmica, decorrentes do processo de expansão capitalista. No momento em que são reconhecidos, há uma pressão para realização de reformas democráticas internas e necessidade de diretrizes 
ustas e eficazes, capazes de enfim conferir concretude e

efetividade a tais direitos.

É neste sentido que os Estados nacionais acabam por assumir certo compromisso com uma agenda de reformas institucionais, voltada ao aprimoramento de capacidades humanas (compreendidas na forma explicitada na seção anterior).

Tais direitos, por outro lado, sofrem duras críticas, que afirmam que o fato de serem declarados como direitos humanos (como pretensões com conteúdo ético universalmente exigíveis) evidencia o descompasso de sua exequibilidade. Enquanto algumas pessoas (sobretudo nos chamados países desenvolvidos) de fato gozam de uma série de benefícios de uma vida materialmente adequada, com empregos bem remunerados, proteção social, previdência, acesso à saúde e educação, outros milhões de pessoas, apesar de igualmente titulares de tais direitos, encontram-se desassistidos por eles. Nestes termos, tais direitos seriam, para tais críticos, mera retórica esvaziada de sentido, posto que inviabilizados pela própria lógica do sistema de produção capitalista.

Tal crítica, aponta Sen, parte do argumento de que, mesmo com os melhores esforços, talvez não seja possível concretizar muitos dos alegados direitos sociais e econômicos para todos. Trata-se de uma observação de dados da realidade, com certo nível de empiria: basta observar sociedades extremamente miseráveis. Se fossem tais direitos facilmente concretizados de forma simultânea à simples declaração de sua existência, nenhuma pobreza haveria. (SEN, 2013)

No entanto, tal crítica tem por base o pressuposto de que os direitos humanos somente podem ser coerentes se puderem ser inteiramente realizáveis para todos. Esse pressuposto é discutível. A pretensão dos direitos humanos, conforme apontamos, é de uma ética universal, e evidentemente há um desejo compartilhado de que todas as pessoas fruam de tais direitos de forma integral. Contudo, tal linha de raciocínio tende a se aproximar do que defendem os utilitaristas, e de sua lógica de maximização de utilidades preexistentes, aplicáveis e extensíveis a qualquer contexto.

Afinal, se exequibilidade fosse condição para que as pessoas tivessem algum direito, todos os direitos seriam absurdos: não seria coerente, por exemplo, reconhecer o direito à vida e sua proteção, já que diariamente pessoas são assassinadas em diferentes conflitos (sejam urbanos, rurais, em países ricos e pobres). A realidade nos diz ser impossível garantir todos os direitos ao mesmo tempo, mas a afirmação dos direitos humanos, antes que um rol de direitos 
social, e não depende parasitariamente de uma exequibilidade preexistente. (SEN, 2013)

Como pudemos ver, a avaliação é um elemento indispensável para a afirmação da defesa e promoção de direitos humanos. As declarações de direitos humanos oferecem elementos de relevante conteúdo ético, sujeitas à discussão pública, ao exame racional e ao debate de diferentes atores $\ddot{i}$ geralmente, no plano internacional, de representantes de governos de países, ou mesmo da sociedade civil ï para que sejam concretizados, pela ação e movimento de agentes que dispõem de razão suficiente para agir a fim de evitar uma violação de um direito humano, de modo adequado às exigências perceptíveis em determinado contexto. Nos dizeres de Joaquín Herrera Flores segundo Flávia Piovesan (2010, p. 96), ñais direitos compõem uma racionalidade de resistência, na medida em que traduzem processos que abrem e consolidam espaços de luta pela dignidade humana.ò

Por estas razões, o direito ao desenvolvimento, ligado estreitamente à noção de direitos econômicos e sociais (ou de iguais oportunidades a todos no acesso a recursos básicos, e um processo de assegurar uma melhoria constante das condições de bem-estar dos indivíduos, agentes participativos desse processo), foi também objeto de reconhecimento em plano internacional, no século XX. Sua efetividade, além de depender do caráter imperativo, da um projeto que deve ser concebido pela ação de diferentes atores, está muito além do plano da simples retórica, esvaziado de sentido. A avaliação concreta, específica, precisa, de contextos de violação de direitos humanos torna o conteúdo de suas declarações instrumentos de transformação da realidade. No caso dos países periféricos, isso fica ainda mais claro, onde a garantia de uma vida de maior qualidade e bem-estar a suas populações depende de esforços complexos, coordenados e atentos às realidades específicas nacionais.

Veremos a seguir em que medida e em quais instrumentos o desenvolvimento passou a fazer parte de uma agenda política de direitos humanos internacionais, a fim de que possamos, no próximo capítulo, aproximar tal agenda ao contexto brasileiro, objeto de nosso estudo.

\subsection{Um debate global. A agenda internacional do direito ao desenvolvimento.}

Os direitos humanos, como vimos, são direitos de natureza universal e indivisível. Seu reconhecimento no plano internacional, por meio de declarações, acompanhou processos históricos de lutas pela emancipação das sociedades modernas. Alicerçados no princípio 

informado, indispensável a seu processo de conquista, alcance, efetividade e reconhecimento. À medida que as pessoas, as organizações da sociedade civil e os próprios governos passaram a se informar sobre o conteúdo das declarações documentais, e a entender e avaliar os próprios contextos, passaram também a dispor de instrumentos formais para lutar pela garantia e concretização de seus conteúdos. As declarações, ao reconhecer direitos como pretensões de um projeto social, realizam um chamado à ação concreta, à participação e à ação para transformação. A história de reconhecimento dos direitos humanos está, assim, intimamente conectada à história de democratização da vida política das sociedades modernas.

Universais porque humanos, indivisíveis porque direitos. Isso traduz o que em essência são os direitos humanos: se apenas ser humano é o requisito fundamental da titularidade de um direito humano, a qualquer pessoa nascida viva tais direitos são reconhecíveis. Daí sua universalidade. Por outro lado, exatamente porque direitos, porque prescrições ou projeções sociais com a necessidade de garantias correspondentes, são indivisíveis e interdependentes. Não há direitos sem formas de garanti-los, e essa garantia decorre de um apoio mútuo, entre direitos civis e políticos e direitos econômicos, sociais e culturais. Em outras palavras, sem liberdades civis e políticas fundamentais que permitam a participação, a expressão, a manifestação, direitos sociais, econômicos e culturais não podem ser reivindicados. Em contrapartida, sem liberdades instrumentais e oportunidades fundamentais de natureza social, econômica e cultural, dificilmente será concebível o uso instrumental de liberdades civis e políticas de forma sistemática, como instrumentos de transformação social e exigência pela concretização de direitos. Nas palavras de Piovesan (2010, p. 98), ños direitos humanos compõem, assim, uma unidade indivisível, interdependente e interrelacionada, capaz de conjugar o catálogo de direitos civis e políticos com o catálogo de direitos sociais, econômicos e culturaisò.

O caráter de integralidade, indivisibilidade e universalidade dos direitos humanos foi trazido para o seio da Declaração Universal dos Direitos Humanos, de 1948. Essa declaração é o marco contemporâneo e internacional dos direitos humanos, destacadamente com visão integral e interdependente desses direitos. A Declaração de 1948 reconhece o ñdireito ao bem estar, à saúde e educação, e direitos sociais, econômicos e culturais indispensáveis à dignidade da pessoa humana e ao livre desenvolvimento de sua personalidadeò. (ORGANIZAÇÃO DAS NAÇÕES UNIDAS, 1948). O documento produzido em 1948 resultou de uma preocupação 
Europa, que desembocou na Segunda Guerra Mundial, alçando os direitos humanos a uma necessidade permanente e vigilante de sua concretização.

É a partir da Declaração de 1948 que diversos instrumentos de proteção dos direitos humanos, no plano internacional, passam a constituir uma agenda de um direito internacional dos direitos humanos, a partir de sistemas normativos de caráter global, alicerçada numa série de pactos, tratados e convenções firmados por diferentes países, que passam a assumir compromissos éticos mínimos de direitos (Convenção sobre os Direitos da Criança, Convenção sobre os Direitos das Pessoas com Deficiência, Pacto Internacional dos Direitos Civis e Políticos e o Pacto Internacional dos Direitos Econômicos, Sociais e Culturais, a título exemplificativo). Em 1993, o caráter de universalidade e indivisibilidade de direitos é reforçado também pela Declaração de Viena, estendendo-os a um conjunto de 171 Estados. (PIOVESAN, 2010).

Ao longo do século $\mathrm{XX}$, o plano internacional de reconhecimento dos direitos humanos foi instrumentalizado pela polarização ideológica entre os chamados primeiro e segundo mundo: os direitos civis e políticos, de primeira geração, herança liberal do chamado ocidente capitalista, e os direitos sociais, econômicos e culturais, que seriam uma espécie de legado defendido pelos países socialistas. Em resposta a esse cenário de polarização, como uma necessidade de disputa ideológica comum, os chamados países do ñterceiro mundoò, subdesenvolvidos, elegeram o direito ao desenvolvimento como elemento de agregação coletiva. É precisamente em 1986, quando a polarização entre primeiro e segundo mundo já se encontra em franca decadência, que a Organização das Nações Unidas adota uma Declaração sobre Direito ao Desenvolvimento, endossada por um conjunto de 146 Estados, e um voto contrário dos Estados Unidos da América. (Ibidem)

Do conteúdo dessa Declaração, pode-se perceber uma certa polarização de interesses entre países ricos e países pobres (ou em desenvolvimento). Os segundos, resolutos em conferir concretude e efetivo cumprimento de tal direito, e os primeiros, cientes das dificuldades concretas de sua efetivação. A noção concreta de desenvolvimento, ao evidenciar diferenças nos estágios das sociedades contemporâneas, acabou evidenciando também uma espécie de disputa concorrencial entre nações: países desenvolvidos não querem abrir mão de suas condições, governos de países em desenvolvimento desejam de alcançar condições concretas de desenvolvimento mais próximas àquelas do conjunto de países centrais. Ainda assim, é expressivo o número total de países aderentes à Declaração. 
de seu artigo $1^{\circ}$, que inaugura o corpo do texto com a premissa que constitui a tônica do próprio texto como um todo:

\begin{abstract}
o direito ao desenvolvimento é um direito humano inalienável do qual toda pessoa humana e todos os povos estão habilitados a participar do desenvolvimento econômico, social, cultural e político, a ele contribuir e dele desfrutar, no qual todos os direitos humanos e liberdades fundamentais possam ser plenamente realizados. (ORGANIZAÇÃO DAS NAÇÕES UNIDAS, 1986, p. 1)
\end{abstract}

O direito ao desenvolvimento é reconhecido a dois destinatários: tanto aos povos quanto aos indivíduos. Além disso, a participação é um aspecto fundamental da própria ideia de desenvolvimento: tomar parte é ser ao mesmo tempo agente e beneficiário, contribuir ao processo de desenvolvimento e dele desfrutar. Os múltiplos aspectos do desenvolvimento são desta forma objeto de apropriação e participação dos interessados: desenvolvimento econômico, social, cultural e político, e se traduzem no objetivo de realização plena de direitos humanos e liberdades fundamentais. Tal tradução aproxima-se da teoria de desenvolvimento como liberdade, conforme vimos anteriormente, ao admitir como objetivo a realização plena de liberdades fundamentais.

No que diz respeito à recíproca, aos deveres de implementação do direito ao desenvolvimento, tanto Estados quanto indivíduos são responsáveis por sua realização. Nos termos da Declaração:

§3. Os Estados têm o direito e o dever de formular políticas nacionais adequadas para o desenvolvimento, que visem ao constante aprimoramento do bem-estar de toda a população e de todos os indivíduos, com base em sua participação ativa, livre e significativa, e no desenvolvimento e na distribuição equitativa dos benefícios daí resultantes. (Ibidem, p. 3)

A importância do Estado na formulação de políticas públicas que viabilizem o desenvolvimento e também a participação dos indivíduos nesse processo fica evidente no texto da Declaração de 1986. Tal previsão é essencial para que possamos conceber uma política nacional de reconhecimento do direito ao desenvolvimento como direito humano.

É possível identificar três dimensões centrais no texto da Declaração sobre o Direito ao Desenvolvimento (PIOVESAN, 2010): justiça social com equidade, igual oportunidade de acessos a recursos básicos, como saúde, educação, alimentação e moradia; participação e accountability, com o dever estatal de favorecer e estimular a livre e significativa participação das pessoas na ñelaboração, implementação e monitoramento de políticas de 
cooperação internacional, assumindo que a realização do direito ao desenvolvimento depende tanto de ações nacionais quanto formas de cooperação internacional. Os Estados, nessa acepção, têm o dever de adotar medidas, de forma individual ou coletiva, voltadas a formular políticas de desenvolvimento internacional, a fim de facilitar a plena realização de direitos, essencial para que os países em desenvolvimento encontrem meios para alcançarem tal fim.

O cerne da declaração de 1986 aproxima-a de ñuma concepção estrutural ao processo de desenvolvimento, amparada normativamente nos parâmetros internacionais de direitos humanos e diretamente voltada à promoção e à proteção dos direitos humanosò (PIOVESAN: 2010, p. 105). Como veremos adiante, no próximo capítulo, essa aproximação entre padrões internacionais e concepção estrutural de desenvolvimento constitui marco da formulação de uma política doméstica, nacional, prevista no Eixo do Direito ao Desenvolvimento, no Terceiro Programa Nacional de Direitos Humanos (PNDH-3).

Em suma, o reconhecimento do direito ao desenvolvimento como direito humano alcançou a agenda política internacional de maneira simultânea à complexificação e oscilações do capitalismo em nível internacional. Não é fortuito o fato de a Declaração sobre o Direito ao Desenvolvimento datar do final da década de 80, sucedendo a crise internacional do petróleo (mencionada no Capítulo I), tampouco o fato de suceder o aprofundamento da crise de manutenção do regime soviético e do socialismo real, nos anos de abertura e reestruturação da Glasnost e Perestroika ${ }^{36}$. Esse contexto internacional demandava respostas, também em nível internacional, do sistema organizado das Nações Unidas, em torno de propósitos comuns, e de mobilizações que consolidassem um conteúdo inadiável: o direito de as pessoas ñdesfrutarem de condições favoráveis do desenvolvimento econômico, sem qualquer tipo de exclusãoò. (CALLEGARI, 2010, p. 495).

Com efeito, apesar de a Declaração sobre o Direito ao Desenvolvimento de 1986 expressar uma visão integrativa de desenvolvimento, assumindo a indivisibilidade e interdependência das diferentes dimensões desse direito (justiça social e igualdade de acessos, manutenção da paz, garantia e respeito de liberdades fundamentais, cooperação internacional

36 A Perestroika foi a completa reformulação da economia planejada soviética, que antecipava a produção e distribuição de bens conforme o planejamento estatal centralizado. Nas palavras de Octávio Ianni, a Perestroika ñpôs em prática mudanças profundas na estrutura do sistema econômico soviético, com a substituição dos mecanismos de economia centralmente planificada pelos mecanismos de economia de mercadoò(IANNI, 1995, p. 12). A Glasnost, por sua vez, foi a politica de abertura do Estado soviético ao maior controle pela sociedade, permitindo maior liberdade de organização e expressão por organizações da sociedade civil e por cidadãos, e maior transparência das atividades estatais, inaugurando certa democratização e o progressivo desmantelamento da União Soviética, rumo a sua fragmentação política. 
imprimir um conteúdo ético de garantias e direitos, simultâneo ao processo de expansão capitalista, que seria verificado com forte expressão já nos fins dos anos 80 e na década subsequente, conforme podemos extrair do gráfico a seguir:

\section{Figura 5: Expansão do Produto Interno Bruto Mundial, 1986-1999 ${ }^{37}$.}

Valor nominal do PIB mundial em trilhões de dólares

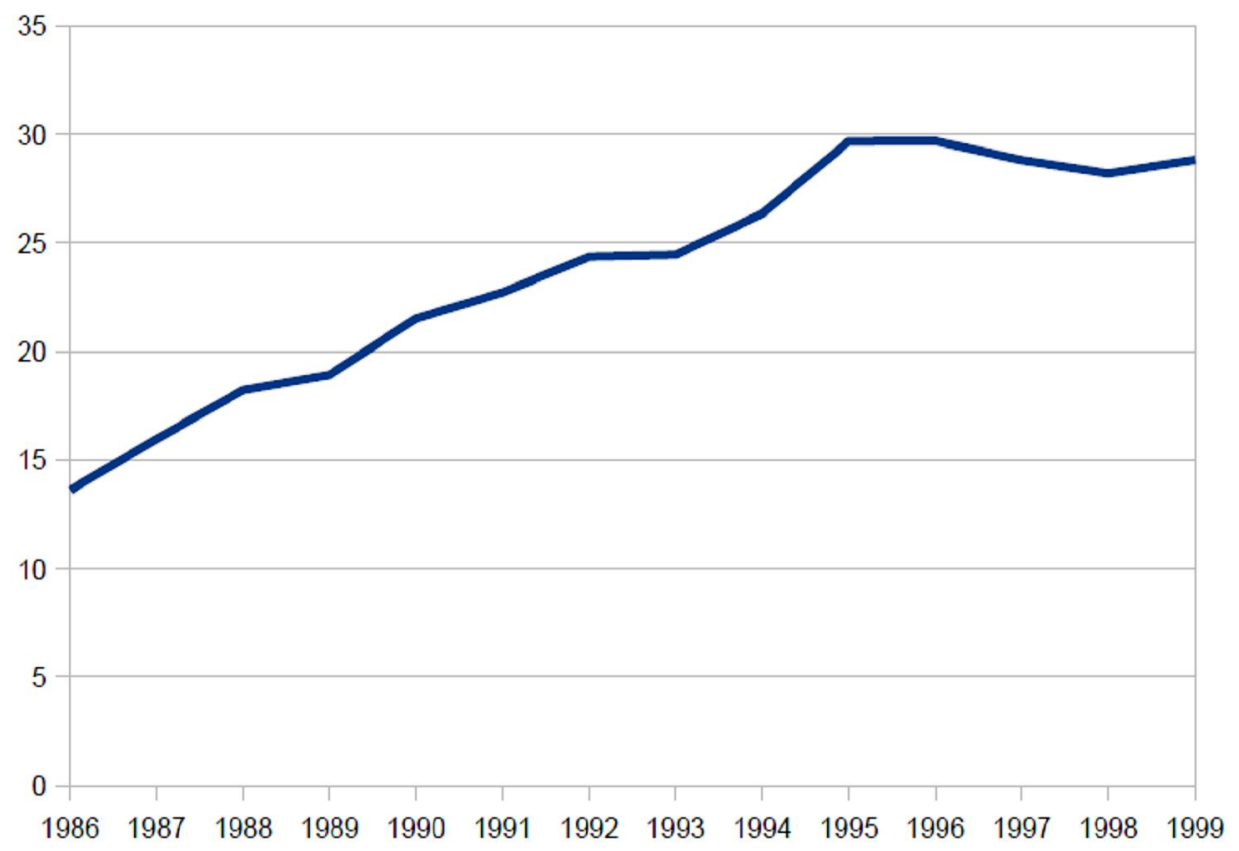

Anos

Podemos observar no gráfico certa tendência ao crescimento da produção mundial entre fins da década de oitenta e início da década de noventa. Essa tendência somente poderia revestir de esperança sobre uma melhoria geral das condições de vida das populações se se reconhecesse simultaneamente o direito a gozar do bem-estar, e de exercer liberdades fundamentais.

A necessidade de um projeto que anunciasse, com urgência, maior justiça social, distribuição e participação dos indivíduos no resultado do incremento da produção mundial se 
não poderia se processar sem que resultados concretos de melhoria das condições de vida das pessoas o acompanhassem. Diante do colapso do socialismo real e de certa hegemonia da liberalização dos mercados, a importância de assegurar direitos num contexto em que a humanidade anunciava o fim das divisões entre primeiro, segundo e terceiro mundo se fazia clara: a hegemonia capitalista não poderia assumir o curso de ignorar as desigualdades que a liberalização econômica reproduzia ou reforçava. $\mathrm{O}$ anseio do terceiro mundo em alcançar estágios de bem-estar e padrões de qualidade de vida foi alçado ao centro do debate internacional.

Nesse cenário, o direito ao desenvolvimento tornou-se um desafio contemporâneo, o que gerou demanda do conjunto de países que endossavam a Declaração de 1986 por instrumentos capazes de auferir seu cumprimento. Entram em cena a construção de indicadores e a adoção de outros instrumentos para mensurar e viabilizar a implementação do direito ao desenvolvimento. Entre eles, podemos destacar a adoção de um tratado internacional para sua efetiva proteção, com força jurídica vinculante, e a ratificação do Protocolo Facultativo ao Pacto Internacional dos Direitos Econômicos, Sociais e Culturais (PIDESC), o que permitiria a proteção e o acionamento judicial desses direitos em diferentes níveis (local, regional e global). Além disso, a mobilização e fomento à cooperação e assistência internacional, e a atuação de atores privados na promoção dos direitos humanos, seriam outros importantes instrumentos para viabilizar essa implementação (PIOVESAN, 2010).

Já dentre os indicadores concebidos para auferir concretamente a implementação do direito ao desenvolvimento, podemos apontar aqueles que compõem os Objetivos de Desenvolvimento do Milênio (ODM, assumidos como compromisso em 2000 e traduzidos em oito propostas concretas que devem ser atingidas até 2015: redução da pobreza, ensino básico universal, igualdade entre os sexos e a autonomia das mulheres, redução da mortalidade infantil, aprimoramento da saúde materna, combate ao HIV/AIDS, malária e outras doenças, garantir a sustentabilidade ambiental e estabelecer uma parceria mundial para o desenvolvimento), e os que compõem o Índice de Desenvolvimento Humano (IDH), ferramenta utilizada pelo Programa das Nações Unidas para o Desenvolvimento desde 1993 e criada pelos economistas Amartya Sen e Mahbub ul Haq em 1990, para medir com maior precisão e abrangência o bem estar e qualidade de vida das pessoas. 
a longevidade, o índice de educação e o PIB per capita como seus componentes. A partir de 2010, o IDH passa a compreender o índice de educação como anos médios de estudo e anos esperados de escolaridade, em substituição à taxa de alfabetização e taxa de escolarização da população. A construção de tais indicadores foi resultado de amplo estudo, e possibilitou que o conjunto de países das Nações Unidas dispusesse de instrumentos concretos para avaliar o desenvolvimento de suas populações, com indicadores que medissem, ainda que parcialmente (e com base em simplificações) o acesso e exercício de liberdades fundamentais: educação (pelo tempo médio de estudo e expectativa de permanência em estabelecimentos de ensino), longevidade (o que simplificaria as noções de acesso a condições básicas de saúde, como atendimento médico, nutrição adequada, acesso a esgoto e água tratados, etc.), e PIB per capita (o que simplificaria a noção de condições materiais de acesso a bens e serviços). Evidentemente, o IDH é apenas um instrumento que tenta mensurar condições de efetivação do desenvolvimento, sem contudo constituir em perfeito indicador de qualidade de vida das pessoas.

Os compromissos internacionais, ainda que constituam importantes marcos de reconhecimento, projeto e chamado à ação, dependem de outros instrumentos de implementação de direitos. O trabalho constante dos organismos internacionais no monitoramento e elaboração de mecanismos de controle e implementação do direito ao desenvolvimento foi respaldado pelo trabalho de Arjun Sengupta, economista indiano e especialista independente para o direito ao desenvolvimento de Grupo de Trabalho Aberto da Organização das Nações Unidas. Responsável por um estudo com o objetivo de viabilizar a implementação efetiva desse direito, sua sugestão foi no sentido de estabelecer um Pacto de Desenvolvimento entre determinado país em desenvolvimento, de um lado, e a comunidade internacional e as instituições financeiras internacionais de outro. Esse Pacto decantaria a compreensão da teoria do desenvolvimento enquanto liberdade, pois o autor assume que ño processo de desenvolvimento facilita e capacita a realização de todas as liberdades e de todos os direitos fundamentais, expandindo ainda a capacidade e a habilidade básicas das pessoas para usufruírem de seus direitosò (NWAUCHE et. NWOBIKE, 2005, p. 97) Contudo, parte da premissa de que o direito ao desenvolvimento é reconhecido aos indivíduos, mas o dever, sua contrapartida, é atribuído aos Estados, sendo que os países desenvolvidos teriam a obrigação de prover assistência, redução da pobreza e cooperação internacional com países subdesenvolvidos. 
nacional do direito ao desenvolvimento foi estabelecida com a finalidade de mobilizar não somente Estados, mas também indivíduos. $\mathrm{O}$ reconhecimento e concretização do direito ao desenvolvimento pretendem-se, assim, ocorrer simultaneamente em âmbitos nacional, internacional, individual e estatal. A responsabilidade dos Estados é de fato fundamental para garantir o exercício de liberdades fundamentais e instrumentais pelos indivíduos, mas tal responsabilidade não garante o pleno exercício desse direito. Por isso, estabelecer instrumentos que auxiliem sua implementação pode ser útil. Contudo, devem preocupar-se com a complexidade desse direito. É a partir dessa premissa multifacetada do direito ao desenvolvimento que analisamos, no capítulo seguinte, a formulação do Eixo a tal direito no Programa Nacional de Direitos Humanos 3.

\subsection{Conclusão}

Conforme pudemos verificar neste capítulo, o conceito de desenvolvimento foi construído à medida que as sociedades capitalistas modernas se tornaram mais complexas, com incrementos demográficos e tecnológicos. A interpretação da modernização ï e de suas consequências ï trouxe à tona o debate a respeito do uso, distribuição e circulação de riquezas, sobre a superação da pobreza, e em que medida a expansão da produção ï e da liberdade de produzir e fazer circular bens e mercadorias, estaria também associada a um processo de expansão das liberdades (substantivas e instrumentais) dos seres humanos. Em última instância, trouxe à tona o debate sobre o desenvolvimento, seus sentidos e percepções. Como vimos, essa última problematização sobre os aspectos do desenvolvimento foi aprofundada pelas contribuições teóricas de Amartya Sen, que tratou o problema do desenvolvimento de forma bastante aproximada à etimologia da própria palavra, associando tal ideia-força ao mais profundo sentido da liberdade humana $̈$ como sua finalidade, senão sua essência.

Fato é que essa visão de desenvolvimento, no entanto, é limitada por um contexto absolutamente criticável, sob muitos pontos de vista: o capitalismo de matiz liberal. Traduzido num sistema que favorece trocas desiguais, com concentração de meios de produção, acesso desigual a mercados, oligopólios de informações e tecnologias, acesso a recursos educacionais distintos, especulação em detrimento da própria produção, direitos de manutenção e reprodução da propriedade em patamares de desigualdade, é um tanto problemático pensar 
se assegurar uma vida de qualidade. Um modelo que favorece o reforço de tais desigualdades, repleto de enormes dificuldades de reversão dessas mesmas desigualdades, posto que ainda não se provou capaz de derrubar de vez a linha imaginária $̈$ e a distinção material real, concreta $\ddot{i}$ que divide o mundo rico, próspero e desenvolvido, do mundo pobre e subdesenvolvido.

O problema da liberdade acompanha o problema da desigualdade. Um dos críticos recentes das roupagens institucionais do capitalismo liberal, Thomas Piketty, assume haver duas principais razões para as desigualdades de renda das pessoas:

ñ desigualdade de renda do trabalho e desigualdade de renda do capital. Quanto mais desigualmente distribuído é cada um desses componentes, maior a desigualdade total. Em abstrato, é perfeitamente possível imaginar uma sociedade em que a desigualdade relacionada ao trabalho é alta e a desigualdade relacionada ao capital é baixa, ou vice-versa, assim como uma sociedade na qual ambos os componentes são altamente desiguais ou altamente igualitáriosò (PIKETTY: 2014, p. 224 , livre trad. do autor).

Não é tampouco o fato de haver a liberdade de mercado que as liberdades e capacidades sejam tolhidas, como alguns autores pregam. As oportunidades econômicas de realizar trocas vantajosas, encontrar o que melhor satisfaça desejos ou necessidades mediatas ou imediatas são garantidas no momento em que também se garante a liberdade de transações, de trocas justas. Nelas, o elemento monetário é revertido em bem ou serviço, a fim de pagar pelos custos de sua produção ou prestação. O valor que excede o custo da produção ou prestação de serviço, lucro que gera investimento para expansão produtiva, pode ser condenável do ponto de vista de reproduzir as próprias desigualdades da já existente concentração de meios de produção. Resolver esse dilema não é tarefa das mais simples, mas um dos pontos cruciais para tanto, estaria, em princípio, em se estabelecer regras de tributação justa, através das quais os que detivessem mais meios de produção pagassem mais por isso, enquanto os mais pobres devessem pagar proporcionalmente menos, em comparação a seu rendimento total e a sua capacidade de gerar rendimento com seu conjunto de bens disponíveis (riqueza).

Evidentemente, estabelecer um equilíbrio entre crescimento demográfico, substituição populacional, ingresso no mercado de trabalho e aposentadoria, entre expansão da atividade produtiva e tributação que a retarde não são cálculos simples, que possam se reverter em maior justiça social e gerar maiores oportunidades, bem-estar e qualidade de vida às populações. No entanto, ao apresentarmos a teoria de desenvolvimento como liberdade, 
tribui com um arsenal teórico essencial para que, no contexto em que tantas desigualdades se evidenciam, as pessoas e os Estados busquem, incansavelmente, concretizar o chamado dos direitos humanos, da realização de liberdades fundamentais, do esforço de cooperação, do rompimento de óbices ao pleno exercício das potencialidades individuais, mediante acesso a direitos e liberdades também fundamentais.

É, portanto, a partir dessa visão teórica que tentamos compreender, no capítulo seguinte, a elaboração do PNDH-3 como marco essencial de uma política de direitos humanos nacional. 


\section{VOLVIMENTO NUMA POLÍTICA DE DIREITOS}

\subsection{Introdução}

Nos dois primeiros capítulos, cuidamos de apresentar as origens e a trajetória do neodesenvolvimentismo brasileiro, e em que medida as contribuições teóricas de Amartya Sen tornaram a ideia de desenvolvimento tão cara à temática dos direitos humanos.

Nossa intenção, neste último capítulo, é estabelecer uma relação entre o conceito de desenvolvimento traçado por Sen e o modelo neodesenvolvimentista, tomando por objeto de análise o Eixo Desenvolvimento e Direitos Humanos, conjunto de objetivos estratégicos, diretrizes e ações programáticas previsto no Terceiro Programa Nacional de Direitos Humanos, o PNDHï 3, de 2009.

Conforme já explicitado na introdução deste trabalho, a reflexão aqui proposta transita por diferentes temáticas, o que torna imprescindível certo rigor metodológico: não se dispensa tal rigor neste capítulo, no qual se propõe a análise de uma política pública cuja concepção se reporta tanto a aspectos teóricos, quanto a desenhos e roupagens institucionais do Estado brasileiro. Daí se justificam os objetos de reflexão do primeiro e segundo capítulos.

Em que pese o fato de o PNDH-3 ser relativamente recente, sua escolha para a análise se justifica por se tratar de um Programa de caráter nacional, situado no final do segundo mandato do governo Lula $\ddot{i}$ no ano de 2009 - e que resgata o histórico de disposições dos Programas (Planos) de direitos humanos antecedentes (PNDH, de 1996 e o PNDH-2, de 2002). O contexto de sua concepção é, desta maneira, informado não apenas pela trajetória de políticas nacionais de direitos humanos, que trouxeram, para o debate das políticas públicas brasileiras, princípios fundamentais dos tratados e compromissos internacionais de que a República Federativa do Brasil é parte, mas também por uma política econômica e de inclusão social específica, concebida no âmbito do governo federal.

Este Capítulo elege, deste modo, a formulação do PNDH-3 como seu principal escopo geral e, especificamente, as discussões em torno do Eixo Desenvolvimento e Direitos Humanos. A análise restringe-se, portanto, às discussões envolvidas no processo de elaboração de política pública, ao resultado concreto dessas discussões, o texto propriamente dito do Programa, e à sua comparação com a opção econômica de matriz neodesenvolvimentista. 


\subsection{A agenda política dos Direitos Humanos: os Programas Nacionais de Direitos Humanos}

Certas áreas temáticas são comumente consideradas objetos de políticas públicas, como Educação, Saúde, Segurança Alimentar e Nutricional, Comércio Exterior, Previdência Social, Assistência Social, Trabalho e Emprego, Defesa ou mesmo Política Fiscal. Todas essas áreas temáticas são lembradas pela relevância que assumem na vida das pessoas. No entanto, quando se considera os direitos humanos como conteúdo de políticas públicas, não raramente se verifica uma certa visão de individuação ou segmentação de tal conteúdo, como se as políticas em direitos humanos fossem exclusivamente direcionadas a grupos vulneráveis e minorias: população de lésbicas, gays bissexuais e transexuais, crianças e adolescentes, negros, mulheres, população de rua ou em situação carcerária, etc. Essa visão restritiva olvida-se da universalidade dos direitos humanos, e acaba resultando em discursos simplificadores e nem sempre verdadeiros sobre o real conteúdo das ações voltadas à proteção e promoção de tais direitos.

Não se duvida da relevância das políticas seccionadas, voltadas a grupos vulneráveis e minorias como política de reconhecimento de diversidade e diferença, e empoderamento para o exercício, em condições de igualdade com as demais pessoas, de outros direitos. O que não é possível admitir é que o objeto das políticas em direitos humanos restrinja-se tão somente a tais parcelas: é preciso, não obstante, enxergar as ações voltadas à universalidade das pessoas, consideradas também em sua igual titularidade de direitos. Por isso mesmo, o direito ao desenvolvimento, a garantia de poder desobstruir amarras e obstáculos que impeçam o livre exercício das potencialidades e talentos individuais é, talvez, um dos mais universais desses direitos.

Nesse sentido, alguns questionamentos se fazem necessários: o que são políticas públicas? Qual a sua importância para os direitos humanos? E em que consistiria uma política pública em direitos humanos?

Segundo Colebatch, policy ${ }^{38}$ é um ñconceito na análise do processo de governoò (COLEBATCH apud HOWLETT et al., 2013, p. 3). Essa definição, um tanto abrangente,

38 Os estudos e análises mais relevantes sobre politicas públicas surgem nos Estados Unidos da América, no século XX, focados na ação dos governos. A principal premissa desses estudos é a de que, nas democracias estáveis, o que um governo faz ou deixa de fazer pode ser objeto de reflexão acadêmica independente. Isso 
pode ser decomposta a partir de suas atividades, dentre as quais estão as políticas públicas. Essa definição coaduna-se com a definição de Thomas Dye, que diz que políticas públicas são ñudo aquilo que um governo decide fazer ou deixar de fazerò(DYE, 1972, p. 2). Apesar de se tratar de uma definição um tanto simples, uma vez que as atividades governamentais vão muito além do conteúdo das políticas públicas, o fato de situar o governo como ator das políticas públicas significa reconhecê-lo como instância de decisão oficial a respeito de um determinado assunto, embora algumas atividades de atores não governamentais possam influenciar decisões de governo, e também auxiliá-lo na implementação de políticas públicas.

Outro conceito de políticas públicas é apresentado por Jenkins, que nos traz uma definição um pouco mais completa:

ñum conjunto de decisões inter-relacionadas, tomadas por um ator ou grupo de atores políticos, e que dizem respeito à seleção de objetivos e dos meios necessários para alcançá-los, dentro de uma situação específica em que o alvo dessas decisões estaria, em princípio, ao alcance desses atoresò (JENKINS apud HOWLETT et. Al, 2013, p. 8)

Tal noção perpassa portanto duas ideias: a de que políticas públicas são um conjunto de decisões, portanto, são complexas e demandam diferentes ações, simultâneas ou sucessivas, e estão voltadas a alcançar um determinado objetivo. A relação entre meios escolhidos para atingir determinado fim é portanto determinante para o campo de formulação de políticas públicas. Nessa definição, vemos que esse cálculo, a escolha entre fazeres (ações) e não fazeres (omissões) é feita por atores políticos, sejam eles estatais ou não, com capacidade de escolha, dentre um leque de opções disponíveis, entre fazer ou não fazer algo.

A língua inglesa possui duas palavras para distinguir esses conceitos: policy e politics, distinção que, em certa medida, denota a interpretação frequente de autores anglófonos, de que as políticas públicas são objetivamente mensuradas como produtos, isto é, resultados de um processo político, decisório. É o que Randall Ripley define serem as políticas públicas: um ñconjunto de atividades realizadas pelos atores, que resultam em produtos identificáveisò (RIPLEY: 1995, p. 158, trad. do autor). Não diferente é o conceito apresentado por Maria das Graças Rua: ñas políticas públicas (policies) são outputs (produtos), resultantes da atividade

teria permitido o desenvolvimento de estudos no campo multidisciplinar dessas políticas, analisadas sob o enfoque da sociologia, da ciência política, da administração, da economia e de outros conhecimentos das chamadas ciências sociais aplicadas. Autores como Guy Peters, Theodor Lowi, Thomas Dye, Laurence E. Lynn Jr. foram responsáveis por conduzir importantes estudos nesse campo. Introduzimos o conceito de políticas públicas pelo uso de policy no texto deste trabalho, a fim de remeter à origem do termo, apresentando a distinção entre policy e politics dois parágrafos adiante. 
imperativa de valores.ò(RUA, 1998, p. 14)

Essas definições apresentam em comum a noção de produto, o que representa uma certa lógica de justificação da existência dos Estados na modernidade capitalista: a de que os cidadãos são usuários, beneficiários desses produtos, e que o Estado (e seus parceiros) são os fabricantes, autores desses produtos. Essa lógica justifica ou reforça a existência do próprio Estado, uma vez que cria uma espécie de simbiose entre Estado e cidadania: imprime nas pessoas um conjunto de expectativas sobre a ação concreta do Estado para resolver problemas comuns, e estimula as pessoas a participarem de processos decisórios, a demandarem por mais resultados e políticas de qualidade, reforçando os mecanismos democráticos indutores de políticas e decisões na estrutura do Estado.

Chama também a atenção a noção de valor, de alocação imperativa de valores, expressa na definição de Rua. Os valores são escolhas, são expressões do que se considera importante num dado contexto espacial e temporal de uma sociedade, por ela mesma ou por grupos de poder a ela pertencentes: preservar o meio ambiente, impedir a mobilidade social, proteger a propriedade privada, educar as crianças para a participação política, garantir que mulheres usem o chador em público, ou garantir liberdades religiosas, de crença e culto, por exemplo. A alocação imperativa desses valores constitui uma exigência ética (um dever ser) da decisão por fazer ou não fazer algo e, comumente, o império da lei (rule of law) é o recurso que legitima essa ação estatal, sobretudo nas democracias ocidentais. Alocar valores é portanto decidir por algo com fundo ético, escolher tomar uma decisão e usar os meios disponíveis para cumprimento dessa decisão.

Nesse sentido, o que seriam políticas públicas em direitos humanos? Ora, como vimos, os direitos humanos são prescrições éticas importantes, que necessitam de adesão racional ampla e constante. Ao constituírem um chamado à mudança, seu fundo imperativo se constitui na medida em que exigem a participação e têm como pressuposto a democracia: em um debate amplo, racional, sobre que prescrições devem ser observadas. Nos dizeres de Sen:

As proclamações de direitos humanos, mesmo que sejam formuladas reconhecendo a existência de coisas chamadas direitos humanos, são declarações éticas realmente fortes sobre o que deve ser feito. Elas exigem que se reconheçam determinados imperativos e indicam que é preciso fazer alguma coisa para concretizar essas liberdades reconhecidas e identificadas por meio desses direitos.

Aqui cabe considerar que a força da afirmação sobre a existência dos direitos humanos se encontra no reconhecimento de algumas liberdades importantes que alegadamente devem ser respeitadas e, por conseguinte, da aceitação por parte da 
as obrigações de apoiar e promover essas liberdades, de uma forma N, 2013, pp. 398 ï 399)

A dificuldade em conceituar ou visualizar uma política pública em direitos humanos é evidente, pela amplitude de objetos a que tais direitos dizem respeito: se considerarmos a visão de Amartya Sen sobre os direitos humanos como proclamações revestidas de conteúdo ético, a fim de conferir concretude a liberdades, é necessário, antes de tudo, definir o conteúdo dessas proclamações, de modo que constituam um chamado à ação em defesa de liberdades fundamentais.

Nesse sentido, a teoria do desenvolvimento como liberdade consubstancia em profundidade o propósito mais caro dos direitos humanos: o de garantir que as pessoas possam exercer suas capacidades e potencialidades de forma livre, desimpedidas de obstáculos e amarras que dificultem seus acessos sociais. O chamado do direito ao desenvolvimento consiste na defesa de que as pessoas exerçam o poder de autodeterminação, e vivenciem essa experiência também em defesa da autodeterminação de seus semelhantes. Situando a liberdade como valor, Amartya Sen faz uma importante observação:

\begin{abstract}
A liberdade é um conceito complexo. Deparar-se com mais alternativas não necessita ser invariavelmente considerado como uma expansão da liberdade de uma pessoa para fazer coisas que gostaria de fazer. Se for dado valor a uma vida sem complicações (e a rotina apressada da constante tomada de decisões não for superestimada), a liberdade para realizar a forma preferida de vida não necessariamente aumentará com a multiplicação de escolhas triviais. (é ) A expansão das escolhas a serem feitas é tanto uma oportunidade (as escolhas podem ser feitas por nós mesmos) e um ônus (as escolhas têm de ser feitas por nós mesmos). (SEN, 2012, pp. 111-112)
\end{abstract}

Reconhecer a liberdade como poder de escolha, e não dever de escolha, é talvez a mais difícil tarefa do chamado ético dos direitos humanos. O poder de escolha é a forma de empoderamento de as pessoas exercerem a vida que mais desejam levar. Trata-se de criar oportunidades para a autodeterminação, e de reconhecer que alguns outros mundos possam caber neste mundo. Não é o fato de as economias capitalistas crescerem sua produção e as pessoas serem inseridas em seus mercados com maiores e mais amplas possibilidades de escolhas triviais que as garanta maior liberdade de poder exercer a vida que mais desejam: uma camponesa que queira uma vida simples, um indígena que queira viver sossegado e longe dos excessos de uma grande cidade, um quilombola que pretenda não mais que se realizar em sua comunidade, com seus semelhantes, não necessariamente são menos livres 
uma série de produtos ou bens para sua satisfação própria.

Esse alerta é importante porque constitui o fundamento ético de realização das pessoas, e constitui também o fundamento dos direitos humanos: situar liberdades enquanto oportunidades, enquanto instrumentos de poder exercer a vida da forma mais aprazível que se pretender, e não como mera multiplicação de escolhas sociais triviais. Trata-se de empoderar as pessoas para poderem se autodeterminar, realizarem-se e, em última instância serem felizes conforme a avaliação de seu contexto e a projeção ideal (e concretizável) de felicidade que pretenderem para si.

Uma política de direitos humanos, portanto, tem por escopo eleger liberdades indispensáveis para que as pessoas possam viver uma vida satisfatória, revertendo em seu benefício, em seu bem-estar, o exercício de tais liberdades, sejam elas instrumentais ou substantivas. Em decorrência dessa necessidade de eleger seus conteúdos éticos, quais liberdades devem ser observadas e garantidas, é que a chamada montagem de agenda das políticas públicas em direitos humanos é indispensável para sua elaboração e concretização.

Segundo John Kingdon,

\begin{abstract}
A agenda (é ) é a lista das questões ou problemas que recebem alguma atenção séria, em algum dado momento, por arte dos funcionários do governo e das pessoas de fora do governo que estão próximas a esses funcionários... Do conjunto de todas as questões ou problemas concebíveis, aos quais os funcionários poderiam estar voltando sua atenção, na realidade prestam séria atenção apenas a alguns, e não a outros. Assim, o processo da montagem da agenda limita esse conjunto de questões concebíveis ao conjunto que de fato se torna foco de atenção. (KINGDOM apud HOWLETT et. al., 2013, p. 103)
\end{abstract}

A agenda dos direitos humanos, ao menos no plano internacional, como vimos no capítulo anterior, remonta ao período pós-segunda guerra, a partir do qual as nações passaram a endereçar questões importantes relativas a direitos humanos, assumir compromissos e fortalecer fóruns multilaterais de compromissos recíprocos. Esse contexto certamente contribuiu para que cada país também concebesse políticas domésticas de proteção e promoção de direitos humanos. A montagem de agenda dos direitos humanos no Brasil, portanto, está intimamente relacionada aos compromissos assumidos pelo país no plano internacional, e as escolhas, princípios e diretrizes dos Programas Nacionais de Direitos Humanos refletem, em boa medida, tais compromissos. 
Áustria, no ano de 1993, que algumas resoluções passaram a impactar concepções de desenvolvimento humano. A Declaração de Viena constituiu-se marco para os direitos humanos, que passaram a ser considerados em seu caráter indivisível, além de ter enfatizado a importância dos direitos de solidariedade, do direito à paz, do direito ao desenvolvimento e dos direitos ambientais.

A participação do Brasil na Conferência de Viena, com a presidência da Comissão Final de Redação, garantiu importante respaldo nas negociações com o conjunto de demais países, e contribuiu decisivamente com o texto do Programa de Ação em seu tópico C (cooperação, desenvolvimento e fortalecimento dos direitos humanos). A partir da Conferência, o governo brasileiro admitiu, em 1995, a crítica situação dos direitos humanos no país e assumiu a necessidade de lançar um programa nesse sentido, que tratasse de temas e questões sensíveis, seguindo a recomendação final da Conferência, de que os Estados-Parte adotassem programas nacionais de direitos humanos. Conforme destaca Lourenço de Almeida:

\begin{abstract}
O Programa Nacional de Direitos Humanos (PNDH) foi lançado pelo Presidente da República, Fernando Henrique Cardoso, em 13 de maio de 1996, por meio do Decreto $\mathrm{n}^{\circ}$ 1.904/1996. Assim, o Brasil foi o terceiro país a cumprir as recomendações da Conferência de Viena (junho ï 93). (é ) O PNDH consolidou, no plano normativo e político, significativo consenso em torno de propostas debatidas entre o governo e diversas entidades da sociedade civil, impulsionadas pelo processo preparatório e seguimento da Conferência de Viena. (é ) A intensa participação nos seminários preparatórios para a elaboração do PNDH evidencia uma evolução positiva no debate entre governo e sociedade antes da elaboração final do PNDH. O programa foi concluído entre novembro de 1995 e abril de 1996, sob a coordenação do então chefe de gabinete do Ministério da Justiça, José Gregori, a partir de projeto básico elaborado pelo Núcleo de Estudos da Violência da Universidade de São Paulo (NEV ï SP). (é ) Sua gênese ode ser explicada a partir das modificações ocorridas, na primeira metade dos anos 90, em relação ao comportamento do Estado e da comunidade brasileira de direitos humanos diante da agenda doméstica e externa do tema. A partir do processo preparatório para a Conferência Mundial de Direitos Humanos das Nações Unidas, inicia-se diálogo entre o Estado e esses atores. Em certa medida, esse contato propicia uma aliança pontual no que diz respeito à estruturação da agenda brasileira de direitos humanos, retirando-a do estágio de mera denúncia das violações, buscando algum consenso para a definição de uma agenda positiva. (LOURENÇO DE ALMEIDA: 2002, pp. 131-132)
\end{abstract}

O diagnóstico sobre a situação dos direitos humanos, à época do governo de Fernando Henrique Cardoso, incentivou a criação de uma agenda de direitos humanos nacional, que encontra fortes características do chamado modelo de mobilização que ñdescreve o processo da construção da agenda em situações em que os líderes políticos iniciam uma política, mas exigem o apoio maciço do público para sua implementação.[..]o problema crucial é 
HOWLETT et. al, 2013, p. 114).

Em que pesem a mobilização da sociedade civil no período de transição entre a ditadura civil-militar e a democratização, sobretudo com a campanha das Diretas Já e o novo marco político inaugurado com Constituição de 1988, a agenda dos direitos humanos no Brasil ainda não contava com respaldo sistemático, articulado e suficientemente mobilizado entre os setores da sociedade civil brasileira no começo dos anos 90, para exigir do governo a formulação de políticas também em caráter sistemático, transversal e complexo de uma agenda inteiramente autônoma, iniciada exclusivamente entre tais setores. Esse diagnóstico demandava uma decisão dos próprios agentes governamentais, em consonância com os compromissos assumidos em Viena em 1993 para estimular e mobilizar a sociedade civil a construir a apresentar suas demandas nessa área. Foi o que aconteceu, num processo iniciado após a declaração do Presidente Fernando Henrique em 7 de setembro de 1995, de

mobilização das organizações da sociedade civil para discutir propostas preliminares
de ação governamental, elaboradas pelo NEV (Núcleo de Estudos sobre a Violência
da Universidade de São Paulo), para serem incluídas no pré-projeto do Plano
Nacional de Direitos Humanos. Ocorreu rápida resposta por parte da sociedade, e em
curto espaço de tempo foram viabilizados seis seminários regionais, reunindo as
organizaçôs mais representativas de direitos humanos, personalidades e
especialistas da área. (LOURENÇO DE ALMEIDA, 2002, p. 136)

Já o PNDH-2, constituído no ano de 2002, foi resultado de uma ampla revisão do Primeiro Programa (que na verdade foi concebido com o formato de Plano), atentando-se para as críticas e recomendações constantes da IV Conferência Nacional de Direitos Humanos, de 1999. Podemos observar que o PNDH 2 constitui-se de forma já distinta do PNDH, sob dois aspectos essenciais: o modelo de montagem de agenda pela via exclusiva de mobilização é relativizado, uma vez que as Conferências Nacionais de Direitos Humanos já se configuravam como experiências em curso (a primeira delas data de 1996), passando a uma maior proximidade ao modelo de iniciação externa de montagem de agenda (HOWLETT et. al, 2013, p. 114) e a própria nomenclatura se altera: deixa-se de lado a ideia de Plano de Direitos Humanos para passar a ser conhecido como Programa, em caráter sistemático, programático, transversal e estruturante, como política de Estado.

O modelo de montagem de agenda pela via de iniciação externa pressupõe que as questões tenham origem nos grupos não governamentais e em seguida expandam seu alcance para chegar à agenda pública e finalmente à agenda formal. Os grupos sociais exercem o papel protagonista de articular reivindicações e cobrar, do governo, ações concretas. 
sociedade civil, diante da trajetória precedente da primeira versão do PNDH, o papel das Conferências Nacionais, a ampliação dos debates internacionais cobre o tema, e o contexto da democracia brasileira. Sob esse aspecto, podemos dizer que a segunda versão do PNDH oscila entre um modelo e outro de formação de agenda (entre o modelo de mobilização e o de iniciação externa), já que tanto governo quanto sociedade civil atuam de forma complementar na construção e elaboração das propostas, tendo a segunda um papel fundamental, posto que a revisão e atualização do Primeiro Programa decorrem de uma demanda dela. Conforme se observa no texto de introdução ao PNDH-2:

O processo de revisão do PNDH constitui um novo marco na promoção e proteção dos direitos humanos no País, ao elevar os direitos econômicos, sociais e culturais ao mesmo patamar de importância dos direitos civis e políticos, atendendo a reivindicação formulada pela sociedade civil por ocasião da IV Conferência Nacional de Direitos Humanos, realizada em 13 e 14 de maio de 1999 na Câmara dos Deputados, em Brasília.

A atualização do Programa Nacional oferece ao governo e à sociedade brasileira a oportunidade de fazer um balanço dos progressos alcançados desde 1996, das propostas de ação que se tornaram programas governamentais e dos problemas identificados na implementação do PNDH.

As propostas de atualização foram discutidas em seminários regionais, com ampla participação de órgãos governamentais e de entidades da sociedade civil e, posteriormente, registradas e consolidadas pelo Núcleo de Estudos da Violência da Universidade de São Paulo ï NEV/USP. Após esforço de sistematização, aglutinação e consulta aos Ministérios e órgãos da área social, sob a coordenação da Casa Civil da Presidência da República, chegou-se a texto com 500 propostas, consideradas todas as categorias de direitos. A Secretaria de Estado dos Direitos Humanos realizou ainda, no período de 19 de dezembro de 2001 a 15 de março de 2002, consulta pública através da internet, dela resultando, após correções e ajustes finais, o texto do PNDH II com 518 propostas de ações governamentais. (BRASIL, 2002, p. 2-4) (grifo nosso)

O papel da sociedade civil como iniciador do processo, e o papel complementar do governo, como elemento de articulação e sistematização das propostas, foram fundamentais ao segundo Programa. Seu marco constitutivo é o Pacto Internacional dos Direitos Econômicos, Sociais e Culturais, também de 1999, sendo que a IV Conferência Nacional de Direitos Humanos que originou o Programa teve como subtítulo: sem direitos sociais não há direitos humanos.

A grande inovação do PNDH-2, além do caráter mais sistemático de suas propostas e a diferença de seu modelo de iniciação, é a de reconhecer a importância dos direitos econômicos, sociais e culturais. Essa inflexão contribuiu para que a agenda dos direitos humanos fosse tornada política de Estado: diferentemente do PNDH-1, em que tais direitos haviam sido eclipsados por razões políticas, o $\mathrm{PNDH}-2$ inova ao reconhecer tais direitos, 
ão esperável do governo fosse recuar em relação a esses temas. Afinal, como exposto no Capítulo 1, o primeiro mandato do governo de Fernando Henrique Cardoso foi marcado por um controle fiscal e cambial rígido, com o intuito de garantir estabilidade macroeconômica, e acabou por inviabilizar uma série de iniciativas que demandassem maior aplicação de recursos orçamentários e extraorçamentários (ADORNO, 2010), além de o segundo mandato ter sido marcado pela crise cambial e a consolidação do chamado tripé macroeconômico (câmbio flutuante, superávit primário e metas de inflação).

O Terceiro Programa Nacional de Direitos Humanos, PNDH ï 3, segue a tônica dos dois primeiros programas, inovando sob alguns aspectos. Sua abrangência é ainda maior, pois decorre do resultado de demandas nascidas em cinquenta conferências temáticas realizadas desde 2003 (educação, saúde, direitos da mulher, crianças e adolescentes, igualdade racial, segurança alimentar, habitação e outras), retomadas e ampliadas a partir do primeiro mandato do Presidente Lula. As demandas organizadas em torno de temáticas específicas permitiu um maior aprofundamento de ações, e se verificou um enraizamento ainda maior das demandas junto à sociedade civil, caracterizando ainda mais o modelo de iniciação externa da formação de agenda.

O PNDH-3, lançado em 2009, é mais extenso, e seu texto foi organizado de forma distinta, articulado em torno de seis eixos fundamentais: interação democrática entre Estado e sociedade civil; desenvolvimento e direitos humanos; universalização de direitos em contexto de desigualdades sociais; segurança pública, acesso à justiça e combate à violência; educação e cultura em direitos humanos; e direito à memória e à verdade. Apresenta 25 diretrizes, 82 objetivos estratégicos e 521 ações programáticas. O texto repete uma série de ações já previstas na Segunda versão do Programa, de 2002, e foi igualmente veiculado por meio de Decreto Presidencial, como já haviam sido as duas primeiras versões. A trajetória dos Programas segue um contínuo de não abandonar ações pregressas, mas adaptá-las ao tempo da edição do novo programa, dada a substituição do programa subsequente em relação ao antecessor. No ano de 2008 foi iniciada a atualização e revisão dos Programas Nacionais de Direitos Humanos I e II, a partir das contribuições feitas na ocasião da $11^{\text {a }}$ Conferência Nacional dos Direitos Humanos.

Para a elaboração do PNDH-3, foram realizados, nos 26 Estados e no Distrito Federal, um total de 137 encontros preparatórios (Conferências Livres, Regionais, Territoriais, PréConferências) às etapas estadual e distrital, que contaram com a participação de cerca de 14 
programa de uma relevante participação social.

Chama a atenção também o fato de o PNDH-3 constituir-se de forma apartidária, como foram os Programas anteriores, espelhando visões de direitos humanos originadas na sociedade organizada, nas recomendações do comitês de monitoramento de tratados da Organização das Nações Unidas e nos próprios Tratados e Convenções de que o Brasil faz parte, não privilegiando nenhum tipo de hegemonia partidária ou visões exclusivas de seus membros de qualquer partido, mas resultado de uma mediação de interesses distintos, expressos por meio de seus mecanismos de participação. Dentre tais mecanismos, além das etapas prévias e Conferências realizadas, o texto do PNDH-3 contou também com uma consulta pública na Internet no ano de 2009, em que a versão preliminar do Programa esteve disponível para sugestões de aperfeiçoamento no sítio virtual da Secretaria de Direitos Humanos da Presidência da República. (BRASIL, 2009)

Curiosamente, mesmo com todas essas características (ampla participação social, mediação de interesses, sistematização de propostas resultantes de diferentes conferências temáticas, consulta pública, apartidarismo), o Programa foi objeto de severas críticas por setores midiáticos, acadêmicos, jurídicos, e políticos, que afirmavam que a Proposta compreendia medida ñsemelhante ao modelo venezuelanoò, seguia o ñestilo da União Soviéticaò, o ñestilo de Hitler e Mussoliniò, e ainda previa uma ñreformulação completa da Constituiçãoo ${ }^{39}$, além de fazer entrar a ñvelha visão esquerdista e ideológicaò ${ }^{40}$

O completo desconhecimento sobre os históricos dos Programas de Direitos Humanos no Brasil e a agressividade retórica de que se valeram setores de opinião expuseram um ódio visceral ao Programa. Também partiram do próprio governo algumas críticas ao PNDH-3, como fez o Ministério da Defesa, que capitaneou a maior parte das retificações ao texto de 2009, consubstanciadas no Decreto $\mathrm{n}^{\mathrm{o}}$ 7.177, de 12 de maio de 2010 (BRASIL, 2010). O recuo com relação a temas como identificação de logradouros públicos com nomes de agentes da ditadura, e o acompanhamento de tramitação judicial de processos originados no período da ditadura civil-militar foram revistos no Decreto $\mathrm{n}^{\circ} 7.177$, em meio a um ano eleitoral.

\subsection{O governo Lula e o contexto de formulação do Programa}

39 Entrevista concedida ao Programa de Televisão Jô Soares, (Programa do Jô, transmitido pela Rede Globo de Televisão) pelo jurista Ives Gandra da Silva Martins em 27 de outubro de 2009, em que tais termos foram utilizados para se referir ao PNDH-3. (JÔ SOARES ENTREVISTA IVES GANDRA SOBRE O PNDH-3, 2009)

40 Reportagem publicada no Jornal Folha de São Paulo, em 12 de janeiro de 2010. (ABREU: 2010). 
Para que possamos analisar a concepção de desenvolvimento constante nas ações previstas no PNDH-3, é preciso, em primeiro lugar, resgatar o cenário em que o PNDH-3 foi formulado. O início das discussões em torno do Programa ocorreu no segundo mandato de Luiz Inácio Lula da Silva, no ano de 2008. O contexto econômico de formulação do Programa é marcado por um certo otimismo das condições gerais, favoráveis, da economia brasileira $і ̈$ apesar do anúncio de uma crise no plano internacional ï com expansão do nível de atividade produtiva, crescimento econômico, reaquecimento do mercado interno, manutenção de superávits no balanço de pagamentos, aumento do poder de compra e intensificação dos programas de transferência de renda.

A trajetória de recuperação do quadro econômico brasileiro, sobretudo no segundo mandato do governo Lula, já se caracterizava por resultados macroeconômicos favoráveis desde 2003. Entre os anos de 2003 e 2010, o Produto Interno Bruto cresceu em média 4,1\% ao ano (BRASIL, 2012). No mesmo período, as contas externas da economia brasileira apresentaram resultados bastante positivos, como é possível se verificar nos superávits do balanço de pagamentos, que perfizeram um total de US $\$ 231,8$ bilhões ao longo do período. (BRASIL, 2013). Tal saldo foi impulsionado em grande medida por um aumento de liquidez até a crise de 2008, e um consequente aquecimento de demanda internacional (sobretudo por parte da República Popular da China e dos Estados Unidos da América), que por sua vez fizeram elevar os preços internacionais de commodities da pauta de exportações do Pais (soja, minério de ferro, laranja, carne, celulose, etc.), e também foi impulsionado por um câmbio favorável, que permitiu reduzir o nível de endividamento público e aumentar as reservas cambiais do país.

Isso assegurou certa resistência do setor das contas externas ao contexto da crise internacional de 2008, somado às taxas de juros (Selic) comparativamente atraentes à entrada de capitais de curto prazo no país (em média 14,8\% ao ano, no período entre 2003 e 2010). (BRASIL, 2010). Some-se ainda a expansão do mercado interno, com recuperação da atividade econômica, o que tornou o país ainda mais atrativo para investidores externos.

É também entre os anos de 2003 e 2010 que os investimentos públicos e privados e o consumo das famílias, que compõem a chamada Formação Bruta de Capital Fixo ï FBKF, sofreram um acréscimo de uma média de 4,5\% e 7,5\% ao ano, respectivamente. Isso impactou a elevação da FBKF, que saltou de 15,3\% do PIB em 2003 para 19,5\% no ano de 2010. (TEIXEIRA et. PINTO, 2012) 
período. Houve melhoria considerável no segundo mandato, em que a dívida líquida total do setor público seguiu tendência de queda a partir de 2003 (54,9\% PIB em dezembro de 2003) até 2010 (39,2\% PIB em dezembro de 2010). (Ibidem)

Também ocorreu uma diminuição importante das taxas médias de desemprego nas principais regiões metropolitanas do país (de 9,3\% em 2007 para 6,7\% em 2010) e um considerável aumento da massa real de rendimentos dos ocupados (um crescimento de cerca de 20\%). Houve também um aumento da mão-de-obra com vínculo formal de emprego, que saltou de 29,5 milhões de empregados em 2003 para 44,1 milhões de empregados em 2010. (BRASIL, Ipeadata, 2012) E vale ressaltar ainda os reajustes frequentes do salário mínimo ao longo do governo Lula (com aumento médio de 5,9\% a.a.), o que provocou um aquecimento de demanda do mercado consumidor interno e uma leve redução da distribuição de renda. (Ibidem, IbIbidem)

Não são desprezíveis os dados sobre a evolução do Produto Interno Bruto per capita, que apontam uma variação de R \$20.913,67, no ano de 2003, para R 23.875,38, em 2010. (BRASIL, IBGE, 2014) Também importa ressaltar a variação da renda domiciliar per capita, que varia de $\mathrm{R} \$$ 640,40 em 2003 para R \$ 838,60 em 2009 (BRASIL, Ipeadata, 2012). Para essa variação positiva, além dos dados de expansão do emprego formal e aumento da atividade produtiva e diminuição das taxas de desemprego, contribuiu também a forte expansão dos Programas Sociais de Transferência de Renda, sobretudo do Bolsa-Família, que saiu de um total de 3,6 milhões de famílias atendidas em 2003, (com transferência de recursos da ordem de $\mathrm{R} \$ 3,4$ bi) para um total de 12,9 milhões de famílias, em 2010 (e transferências que perfizeram $\mathrm{R} \$ 14,6 \mathrm{bi}$ ). (BRASIL, Ipeadata, 2012). Isso contribuiu para uma expressiva redução do percentual de pessoas pobres da população geral, que caiu de 35,8\%, em 2003, para 21,4\% da população, em 2009. (BRASIL, Ipeadata, 2012).

Merece destaque, ainda, a reorganização e expansão do serviço público brasileiro, que no período Lula (2003-2010), contou com o ingresso de 155.334 novos servidores por meio de concurso público, para exercerem cargos na administração pública federal, o que aumentou o número de servidores civis da ativa em 17,9\%. (BRASIL, Ipeadata, 2012) Essa reorganização do serviço público representou a ampliação das chamadas capacidades estatais, para a qual a expansão de força de trabalho qualificada para a prestação de serviços públicos é uma cara ferramenta. 
de dependência de trajetória, como apontamos no Capitulo 1, foi responsável pelo aumento não desprezível da dívida interna do setor público, mesmo num contexto em que os superávits primários chegaram a um total de $\mathrm{R} \$ 758,8$ bilhões entre 2003 e 2010 (BRASIL, 2010). Isso contribuiu fortemente aos ganhos do setor financeiro.

A manutenção de uma taxa de juros em níveis elevados, sobretudo no primeiro mandato, em um contexto de câmbio flexível, provocou a valorização do real. Essa valorização por sua vez resultou em certa redução de preços de produtos importados e também uma redução das receitas dos exportadores, o que impactou o poder econômico e político de segmentos da grande burguesia industrial, fazendo-a voltar sua produção ao mercado interno (TEIXEIRA et. PINTO, 2012). Houve também variação no câmbio, com certa desvalorização do Real no segundo mandato de Lula, o que provocou redução das importações de máquinas e tecnologias para o setor industrial. A política cambial do governo Lula, apesar de ter sofrido com essa desvalorização sobretudo a partir da crise internacional de 2008, assegurou um aumento das reservas internacionais do país.

Em contrapartida, os setores da burguesia financeira foram importantemente beneficiados nesse período, com taxas de juros, ainda que reduzidas ao longo do tempo, ainda comparativamente atraentes ao setor financeiro. O governo Lula reconhecidamente reduziu a taxa de juros oficial Selic, de 25,5\% em 23 de janeiro de 2003, para um patamar de 10,75\% em 9 de dezembro de 2010. (BACEN, 2014), e também promoveu significativa queda das taxas de juros reais (aquela que desconta o percentual de inflação) no período entre 2003 e 2010, saindo de $12,5 \%$ ao ano para uma taxa de $4,8 \%$ ao ano. No entanto, mesmo com a diminuição, o Brasil liderava nesse período o ranking de países com maiores taxas reais de juros do mundo, o que certamente favorecia os setores financeiros. (CURADO, 2011)

A partir de 2006, com o crescimento da economia puxado também pela dinâmica interna, verificou-se um leve fortalecimento de fatias da indústria e do comércio nacionais, que passaram a exercer maior influência sobre os núcleos de poder do Estado brasileiro.

Ao ampliar as capacidades estatais, o governo Lula possibilitou também a sedimentação de segmentos específicos da burguesia no poder, tendo a burguesia financeira permanecido forte e em papel privilegiado, e as burguesias dos setores produtivos ora ou outra beneficiadas por politicas cambiais, tarifárias e fiscais (industrial e sobretudo agrícola). Por outro lado, promoveu a inserção, ainda que superficial, de pobres, que passaram a 
O governo Lula conseguiu, ao longo de oito anos, a façanha de um reformismo que, ainda que classificado como ñfracoò (SINGER, 2012) por não alterar as desigualdades socioeconômicas de forma estrutural, conseguiu beneficiar fatias nada desprezíveis da sociedade brasileira, compondo uma verdadeira coalizão de forças sociais no cerne de uma economia emergente. Fez, ainda que marginalmente (e, como vimos, herdando práticas e visões predecessoras, sem alteração estrutural de questões como os grupos e segmentos no exercício do poder), o que Bresser-Pereira defende como proposta de seu novodesenvolvimentismo:

desde o começo deste século, comecei a desenvolver um sistema novo de pensamento que hoje já é uma coisa bastante estruturada: uma economia política e uma macroeconomia novo-desenvolvimentistas. A economia política está baseada na idéia de uma coalizão de classes desenvolvimentista e portanto em um Estado desenvolvimentista que é essa coalizão formada por empresários, trabalhadores e a burocracia pública ï para se opor à coalizão de classes liberal ou neoliberal, formada fundamentalmente por capitalistas rentistas, por financistas, que administram a riqueza dos primeiros, e por uma classe média também rentista bastante grande. A meu ver este é o conflito que existe nas sociedades capitalistas, que existe no Brasil, nos EUA ou na França. Então, o que procuro é primeiro entender a lógica dessa coalizão de classes, suas contradições, dificuldades etc.. Sobre isso eu tenho todo um conjunto de trabalhos. E depois tenho a teoria econômica, que vai ser uma microeconomia e uma macro. (BRESSER-PEREIRA, 2014)

Com efeito, a coalizão de forças dos governos Lula (2003-2010) apresentou um forte componente de atendimento simultâneo de interesses, que atravessou desde setores mais pobres da sociedade às camadas do setor financeiro e rentista. Em grande medida, o conjunto de reformas e expansão de capacidades estatais promovido nesse período foi favorecido por um contexto internacional extremamente favorável à entrada de divisas, e por um saneamento fiscal do Estado, o que permitiu também o financiamento das políticas de interesse desses diferentes setores.

Por outro lado, apesar do otimismo que marcou esse período, com relação às perspectivas econômicas e a possibilidade de financiamento de políticas especificas, o que o neodesenvolvimentismo produziu foi uma concertação conjuntural de classes, sem tocar com profundidade em consequências históricas do processo de acumulação capitalista brasileiro, dentre as quais se sobressai, de forma relevante, a imensa desigualdade social. O que acontece no período, de fato, foi uma inclusão importante, porém marginal da população mais pobre nos mercados de trabalho e consumo, e uma expansão não desprezível de sua renda. No 
que sua participação na renda nacional permanece muito superior a qualquer estrato da população, e que sua renda não foi profunda nem significativamente alterada nos anos Lula, conforme podemos observar no gráfico a seguir:

\section{Figura 6: Distribuição do rendimento. Participação do quintil dos $10 \%$ superior no total da renda nacional $(1995-2009)^{41}$}

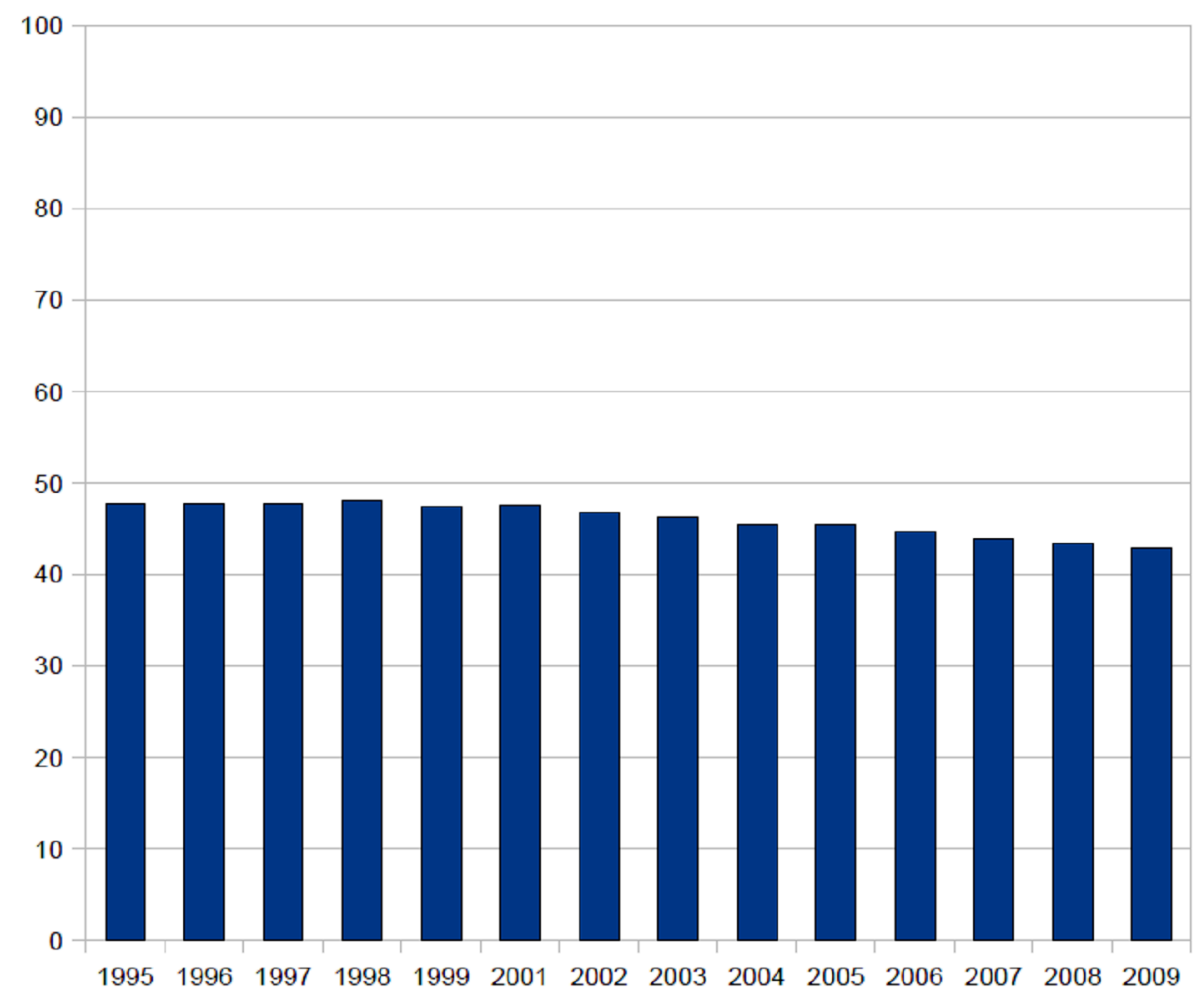

Como é possível se verificar, os dez porcento mais ricos da população respondiam, até 2009 , por mais de quarenta porcento de todos os rendimentos nacionais. Isso revela o quão concentrada é a renda nacional e, em grande medida, também a enorme desigualdade social que separa a população mais rica da população mais pobre do Brasil. Certamente, a renda não é o único fator responsável pela desigualdade social, mas tem um importante peso relativo para a manutenção desse quadro.

Um estudo inédito, divulgado recentemente por Medeiros, Souza e Castro (2014) cruzou os dados da Pesquisa Nacional por Amostra de Domicílios, realizada pelo IBGE, com os dados da Declaração do Imposto de Renda de Pessoa Física. O resultado do estudo revela 
sil permanece muito alta e estabilizada entre os anos de 2006 e 2012. Revela também que quase metade de toda a renda produzida no Brasil está concentrada nos $5 \%$ mais ricos, e um quarto dessa renda, no $1 \%$ mais rico, e ainda que o milésimo mais rico da população brasileira acumula mais renda que o total da metade mais pobre da população (MEDEIROS, SOUZA e CASTRO, 2014). Segundo os autores,

\begin{abstract}
isso reflete um perfil que já é bem conhecido: o Brasil é marcado por uma grande massa de população de baixa renda que se distingue de uma pequena, porém muito rica, elite. Esse perfil não se altera significativamente ao longo do tempo. Há mudanças no longo trecho da base da distribuição que vai do $0 \%$ ao $90 \%$ mais pobres, mas a concentração no topo é bastante estável, especialmente acima do $1 \%$ mais rico. (Ibidem, p. 27)
\end{abstract}

O modelo de perda da legitimidade política da agenda do Consenso de Washington, que caracterizou em alguma medida o neodesenvolvimentismo brasileiro e que, segundo Gomide e Pires r̃recolocou um papel central para o Estado no processo de desenvolvimentoò (2014, p. 15), e resgatou um ativismo estatal sem estatismo (ARBIX e MARTIN, 2010), por meio de ferramentas que estimulam o mercado ao mesmo tempo que também investiu em políticas sociais de combate à miséria. No entanto, esse modelo não tocou com intensidade e profundidade na apropriação da renda nacional, o que proporcionou a continuidade de ganhos comparativamente muito distantes entre pobres e ricos, reforçando as desigualdades sociais já existentes.

Em última análise, o neodesenvolvimentismo pode ser caracterizado por uma forma de gestão do sistema capitalista no Brasil, constituído na era Lula, que conseguiu beneficiar diferentes segmentos da sociedade brasileira, por meio da diversificação da atuação e participação do Estado em uma ampla gama de políticas públicas, com programas de estímulo e expansão do crédito com taxas subsidiadas por bancos públicos, investimentos em infraestrutura, ampliação de programas de transferência de renda e mesmo de outras políticas, como as de acesso ao ensino superior sem, contudo, deixar de possibilitar o enriquecimento dos setores financeiros e rentistas, beneficiados por taxas de juros ainda comparativamente vantajosas em relação ao resto do mundo (ainda que tenham sido objeto de algumas importantes reduções).

Essa forma de gestão do capitalismo e de suas crises no país atentou-se a uma expansão do emprego e da renda de classes trabalhadoras, sem desatentar-se, em contrapartida, com os ganhos de investimento de capital financeiro, e os ganhos de renda historicamente díspares entre capitalistas e trabalhadores. Márcio Pochmann reconhece que, 
ser registradas alterações substanciais na estrutura dos postos de trabalho concentrados fundamentalmente na base da pirâmide social do país.ò(2014, p. 139), o que produziu um aquecimento de demanda interna, um aumento da mobilidade social e uma inclusão pela via do consumo, de pessoas à margem de acessos os mais simples das economias de mercado (como produtos da cesta básica).

Outro dado do período, o índice de Gini, que mede a intensidade da desigualdade social nos países, decresceu de 0,58, no ano de 2002, para 0,53, no ano de 2010. Apesar de uma queda semelhante não ter sido observada em outros momentos históricos, conforme pontua Singer (2012), pode-se afirmar que essa variação ainda é pequena, não tendo sido alteradas, de forma estrutural, as condições principais da desigualdade social brasileira. Um dos pontos nevrálgicos dessa desigualdade está exatamente na estrutura da tributação, que comparativamente à renda, tributa proporcionalmente muito mais dos ganhos de trabalhadores com menores faixas salariais que os segmentos mais ricos da população, no que comumente é chamado de sistema regressivo de tributação, inalterado no período Lula.

Portanto, o que o contexto de práticas neodesenvolvimentistas na política econômica conseguiu, em linhas gerais, foi disponibilizar uma não menosprezível expansão da renda do trabalho e do emprego no período, aliado à expansão de políticas sociais de transferência de renda (com a expansão de previdência a trabalhadores rurais, aprimoramento do cadastro único de assistência social, integração de benefício sociais no Bolsa-Família), favorecido sobretudo por ajustes fiscais e um contexto favorável a setores exportadores, sem alterar os ganhos dos segmentos mais ricos da população, e sem alterar algumas razões que reforçam desigualdades. Manteve os pressupostos macroeconômicos de funcionamento da economia: câmbio flutuante, superávit primário e metas de inflação, ao mesmo tempo em que conseguiu gerar empregos formais no mercado de trabalho e expandir os ganhos salariais.

\subsection{O PNDH-3 e uma inovação: o direito ao desenvolvimento}



ações em linhas de atuação claras, estruturantes, o que constitui um fator de facilitação do monitoramento da implementação de iniciativas. Apesar de o PNDH-2 ter sido elaborado no contexto em que o Pacto Internacional dos Direitos Sociais, Econômicos e Culturais já havia sido objeto de mobilização da Própria Conferência Nacional que delineou as diretrizes do Programa, ele não contempla, de forma sistemática, os direitos econômicos, mas sobretudo os direitos sociais (como direito à assistência e previdência social, ao trabalho, moradia, acesso à terra, saúde, alimentação). Tais direitos são igualmente contemplados pelo PNDH-3, que agrega, além destes, também ações voltadas à promoção de direitos de natureza econômica, como o incentivo à produção local, a técnicas de manejo sustentável, políticas de geração de renda, fomento a tecnologias com redução de danos à saúde, fortalecimento da agricultura familiar, a defesa da concorrência, dentre outras questões.

As duas primeiras versões dos Programas Nacionais de Direitos Humanos mencionam apoio à formulação e implementação de politicas e ações sociais para reduzir desigualdades econômicas, sociais e culturais, com vistas à plena realização do direito ao desenvolvimento. O Subsídio para Revisão e Atualização do Programa Nacional de Direitos Humanos ï PNDH, documento elaborado em 2008 pela então Secretaria Especial de Direitos Humanos da Presidência da República, para auxiliar processo de revisão e sistematização dos Programas anteriores, reconhece a dispersão do tema do direito ao desenvolvimento (o que talvez tenha também contribuído para sua organização posterior em um Eixo temático específico). Vejamos:

Como se trata de uma meta que abrange diversas temáticas e ações em direitos humanos, as informações pertinentes estão demonstradas em outros itens mais específicos do PNDH, como por exemplo, na garantia do direito à igualdade (mulheres, povos indigenas, afrodescendentes, idosos, pessoas com deficiência, LGBT) e garantia do direito ao trabalho e acesso à terra. (BRASIL, 2008, p. 1)

Essa preocupação foi estruturada em torno do Eixo Desenvolvimento e Direitos Humanos, que trouxe uma série de ações, em princípio muito distintas entre si, mas agregadas a partir de um ponto de sustentação comum: a visão do desenvolvimento como conceito complexo e multidisciplinar. A Introdução a tal eixo torna ainda mais clara essa visão:

O tema desenvolvimento tem sido amplamente debatido por ser um conceito complexo e multidisciplinar. Não existe modelo único e preestabelecido de desenvolvimento (...)

A teoria predominante de desenvolvimento econômico o define como um processo que faz aumentar as possibilidades de acesso das pessoas a bens e serviços, 

de um país, refletindo transições de estágios mais baixos para estágios mais altos, por meio da adoção de novas tecnologias que permitem e favorecem essa transição. Cresce nos últimos anos a assimilação das ideias desenvolvidas por Amartya Sen, que abordam o desenvolvimento como liberdade e seus resultados centrados no bem estar social e, por conseguinte, nos direitos do ser humano. (BRASIL, 2009, p. 41) (grifos nossos)

O acesso a bens e serviços, a expansão qualitativa por meio da expansão das capacidades e do âmbito das atividades econômicas endossa o ponto de vista apresentado por Celso Furtado, conforme pudemos expor brevemente no Capítulo 2, do aspecto distributivo do desenvolvimento. Mas não apenas: reconhece como meio para a promoção do desenvolvimento humano a questão do desenvolvimento econômico, e que o simples crescimento econômico não garante, de forma automática, bem-estar:

acreditava-se que, uma vez garantido o aumento de bens e serviços, sua distribuição ocorreria de forma a satisfazer a necessidade de todas as pessoas. Constatou-se, porém, que, embora importante, o crescimento do PIB não é suficiente para causar, automaticamente, melhoria do bem-estar de todas as camadas sociais. (Ibidem)

Além do desenvolvimento econômico, por meio da garantia de medida qualitativa de progresso de um país, o Programa reconhece expressamente a importância da teoria de desenvolvimento como liberdade, sendo o Eixo Desenvolvimento e Direitos Humanos o único dentre os seis Eixos do PNDH-3 a mencionar expressamente um autor, Amartya Sen, como referência teórica e conceitual.

É possível observar, a partir da análise mais geral das ações previstas no Eixo Desenvolvimento e Direitos Humanos, um esforço de agregar, a partir da experiência pregressa de governos democráticos, a transformação dessas experiências de governo, em princípio desconexas, em uma política de Estado de direitos humanos. A sistematização de propostas ï concretas ou de conteúdo concretizável, possível de serem mensuradas se implementadas ou não ï na área de desenvolvimento parte do know-how precedente, da trajetória de uma crescente ampliação de capacidades estatais, espelhada na criação e inovação no campo das políticas públicas. Como vimos no Capítulo 1, essa ampliação de capacidades estatais fica ainda mais mais clara com a matriz neodesenvolvimentista, e os governos que a promoveram (e não somente eles, pois é possível identificar iniciativas de outros governos que auxiliaram as propostas), que inovaram numa série de políticas em diversas áreas. Essa experiência foi aproveitada na articulação de uma política mais geral de direitos humanos. O quadro a seguir espelha certa correlação entre programas de governo 
Humanos:

Figura 7: Correlação de Ações do Eixo Desenvolvimento e Direitos Humanos do PNDH3 e Programas de Governo instituídos em governos antecessores

\section{Ações}

a) Ampliar e fortalecer as políticas de desenvolvimento social e de combate à fome, visando a inclusão e a promoção da cidadania, garantindo a segurança alimentar e nutricional, renda minima e assistência integral às famílias.

b) Expandir politicas públicas de geração e transferência de renda para erradicação da extrema pobreza e redução da pobreza.

e) Incentivar as politicas públicas de economia solidária, de cooperativismo e associativismo e de fomento a pequenas e microempresas

h) Erradicar o trabalho infantil, bem como todas as formas de violência e exploração sexual de crianças e adolescentes nas cadeias produtivas, com base em Códigos de Conduta e no Estatuto da Criança e do Adolescente.

b) Fortalecer a agricultura familiar camponesa e a pesca artesanal com ampliação do crédito, do seguro, da assistência técnica, da extensão rural e da infraestrutura para comercialização.

c) Fomentar tecnologias alternativas para substituir o uso de substâncias danosas à saúde e ao meio ambiente, como poluentes orgânicos persistentes, metais pesados e outros poluentes inorgânicos.

b) Fortalecer o sistema brasileiro de defesa da
Programas e Experiências antecedentes

Programa Bolsa-Familia, Programa Fome Zero, Programa Nacional de renda mínima vinculado à Saúde - Bolsa-Alimentação, Programa Nacional de Acesso à Alimentação - PNAA

Beneficio de Prestação Continuada (BPC), Programas de Transferência de Renda (BolsaEscola, Vale-Gás, unificados no Bolsa-Família), Programa de Transferência Condicionada,

Programa Economia Solidária em

Desenvolvimento, instituição do Simples Nacional (regime simplificado de tributação reduzida de micro e pequena empresas), instituição da figura jurídica nova, Microempreendedor Individual (MEI), Programa Nacional de Microcrédito Produtivo Orientado (PNMPO)

Programa de Erradicação do Trabalho Infantil (PETI), de 1996.

Programa Nacional de Fortalecimento da Agricultura Familiar (PRONAF), de 1996.

Programa Nacional de Produção e Uso do Biodiesel, de 2004.

Estruturação e definição de competências do 
A organização do Eixo Desenvolvimento e Direitos Humanos partiu assim de dois pressupostos: (1) complexidade e multidisciplinaridade conceitual, o que demanda ações em diversas áreas e valoriza as experiências pregressas de programas de governo em diversos campos de políticas públicas, e (2) o pressuposto teórico do desenvolvimento como liberdade. Enquanto o primeiro se apoia no conjunto de experiências de capacidades estatais ampliadas, conforme apresentamos brevemente no primeiro Capítulo, o segundo demanda a seguinte reflexão: em que medida ele se apresenta nessa política, se aproximando ou se distanciando do próprio modelo neodesenvolvimentista, vigente à época da formulação do PNDH-3?

Como pudemos observar no Capítulo 2, a teoria do desenvolvimento como liberdade não tem como escopo afirmar uma igual liberdade dos seres humanos sem se ocupar com a avaliação das condições objetivas que os impedem de exercer plenamente suas potencialidades e se realizar. A avaliação de que processos permitem maior liberdade de escolha, conforme condições sociais e pessoais, fica, em certa medida, transparecida nas ações previstas no Eixo Desenvolvimento e Direitos Humanos do PNDH-3.

De forma geral, as ações previstas no Eixo Desenvolvimento e Direitos Humanos do PNDH-3 estão organizadas em torno de três diretrizes: (1) efetivação de um modelo de desenvolvimento com inclusão econômica e social, ambientalmente equilibrado e tecnologicamente responsável, cultural e regionalmente diverso, participativo e não discriminatório; (2) valorização da pessoa humana como sujeito central do desenvolvimento; e (3) promover e proteger direitos ambientais como Direitos Humanos, incluindo as gerações futuras como sujeitos de direitos. (BRASIL, 2009).

As ações previstas na diretriz de número (1) são bastantes distintas entre si. É possível observar em seu conjunto uma atenção especial à erradicação e redução da pobreza, garantia de renda mínima e assistência integral a famílias, assim como geração de emprego e renda para a população rural, o combate à pobreza urbana e rural, o avanço na implementação da reforma agrária como política de inclusão social, ações de incentivo ao cooperativismo e à economia solidária, o fortalecimento da agricultura familiar camponesa e a pesca artesanal (BRASIL, 2009). Esse conjunto de ações de inclusão são bastante adequados à decisão resoluta que o neodesenvolvimentismo assumiu ao longo do governo Lula, de erradicação da pobreza extrema no país. 
da pobreza recentemente implementada com relativo sucesso no Brasil parte de um conceito monetarista de pobreza, cuja premissa é de que a principal privação das pessoas pode ser traduzida na ausência de liberdade de adquirir bens e serviços (essenciais ou não) num mercado de consumo, em razão da privação objetiva de acesso a uma quantia monetária para realizar essas trocas. Essa visão da pobreza não é a mais sistemática ou aprofundada, mas traduz uma importante política ampliada e estruturada no governo Lula, que serviu de base à expansão do mercado interno brasileiro e à criação do já apresentado ñcírculo virtuosoò de superação da pobreza: o Bolsa-Família e os demais programas sociais de transferência de renda (como o Benefício de Prestação Continuada).

A universalização dessas políticas sociais, cujo resultado é traduzido no chamado crescimento com inclusão social, permite duas visões: a de que, ao considerar universalidade de um bem, um benefício igualmente concedido (um valor monetário), tenderia a se aproximar de uma perspectiva welfarista, que ignora os aspectos mais específicos da pobreza, pessoais e circunstanciais dos quais decorrem privações dos mais diversos tipos; ou estaria voltada à perspectiva do desenvolvimento como liberdade, uma vez que permitiriam o exercício de capacidades, isto é, de condições externas, objetivas, para realizar funcionamentos relevantes enquanto componentes de maiores capacidades das pessoas; permitindo as chamadas liberdades substantivas (alguém é capaz de fazer algo, dada a oportunidade de fazer esse algo, podendo também escolher não fazê-lo).

A primeira perspectiva somente seria correta se o valor do benefício concedido estivesse vinculado à compra de um ou outro produto ou serviço. Com efeito, não é o que ocorre. A liberdade de avaliar suas próprias condições e reverter o valor desses benefícios recebidos na forma que a pessoa beneficiária, geralmente responsável pela unidade familiar, considerar mais adequada para suprir suas necessidades e de seu grupo familiar, é pressuposto da concessão de benefício, o que se dá em espécie monetária, sem vinculação ou restrição. A liberdade de escolha por meio da abstração monetária, que permite realizar trocas nos mercados das economias capitalistas, é assim pressuposto dessa política, e um importante alicerce de expansão do mercado interno e de inclusão, ainda que periférica, dos pobres nessa economia de mercado. Entretanto, a simples transferência de renda não necessariamente ataca outras causas e consequências da pobreza.

Por outro lado, o Eixo Desenvolvimento e Direitos Humanos externa uma preocupação que vai além da perspectiva monetarista, ao entender a pobreza em seu aspecto multidimensional, que varia conforme espaço, comunidade, forma e natureza de privação. 
aduna com o que Amartya Sen considera indispensável à elaboração de política de redução de desigualdades sociais:

uma recomendação de política está condicionada à exequibilidade, mas o reconhecimento da pobreza tem de ir além disso. Pode-se argumentar que o primeiro passo consiste em diagnosticar a privação, e relacionado com ele, determinar o que devemos fazer se tivermos os meios. E então o próximo passo é fazer escolhas de políticas reas em conformidade com nossos meios. Neste sentido a análise descritiva da pobreza tem de ser anterior à escolha de políticas. (SEN, 2012, p. 171)

A importância da avaliação é central ao sucesso, à exequibilidade de uma política de direitos humanos. As diferentes expressões da pobreza, assim como os diferentes contextos e meios de sua superação revelam-se ter precedido a elaboração das ações previstas no Eixo Desenvolvimento e Direitos Humanos do PNDH-3. Uma descrição atenta das condições diversas de pobreza no Brasil foi necessária para estruturar ações mais concretas para erradicação da pobreza. Apesar do caráter parcialmente generalista das ações, dado que a agenda ali contida é de expressão nacional, observa-se também um conteúdo mais ocupado com o desenvolvimento de forma regionalizada, especificada conforme o contexto de superação.

Essa preocupação com as diferentes expressões da pobreza é indicada no texto das ações do Programa, que se voltam, por exemplo, a comunidades tradicionais, quilombolas e indígenas, e às possibilidades de enfrentamento da pobreza, inclusão produtiva e fomento à produção nos meios urbanos e rurais, sem descuidar de uma lógica regionalizada dessa proposta de desenvolvimento. Ações de estímulo à economia solidária, ao associativismo e cooperativismo sustentáveis, à agricultura familiar e atividades econômicas agroecológicas também refletem essa preocupação.

Dentre as ações previstas previstas na diretriz de número 5 do Eixo Desenvolvimento e Direitos Humanos, voltadas à valorização da pessoa humana como sujeito central do processo de desenvolvimento, uma ação bastante sensível ao projeto neodesenvolvimentista diz respeito à participação e controle social em políticas públicas de desenvolvimento com grande impacto socioambiental. Afinal, o modelo neodesenvolvimentista, ao retomar capacidades do Estado para oferecer uma estrutura que viabilize e estimule a produção ï por meio da viabilização de construção de estradas, aeroportos, hidrovias e ferrovias, ou a produção de energia ï , acaba também entrando em choque com interesses e visões de mundo diversos, sobretudo de povos e comunidades não diretamente estabelecidos na lógica de 
essas condições, seria o desenvolvimento um empecilho à diversidade, à existência humana contrassistêmica? Resultaria o desenvolvimento num processo com a tendência de esmagar a diferença local, em prol de um projeto supostamente universal de bem-estar?

As ações previstas no Programa apontam certa mitigação desse conflito: afirmam a importância de consultas prévias, diálogos, transparência de execução de grandes obras e projetos e capacitação qualificada e participativa de comunidade afetadas por tais obras e projetos (BRASIL, 2009). Há uma intenção de mediar o possível conflito entre as ações de grandes obras e empreendimentos e comunidades tradicionais, estimulando o debate e prevendo consultas em atenção à previsão da Convenção no. 169, da Organização Internacional do Trabalho, a qual o Brasil é signatário.

A proposta de mediar os eventuais conflitos adequa-se à ideia de garantia de liberdades propostas por Amartya Sen, uma vez que os funcionamentos úteis a uma vida de qualidade, como acesso a água encanada, energia elétrica, rede coletora de esgoto e outros serviços públicos devem estar disponíveis para aqueles que os considerem úteis, para que possam ser revertidos em seu próprio benefício. Tratam-se de funcionamentos, ou seja, de alternativas com acesso disponível. Nos dias atuais, dificilmente uma comunidade conseguiria se manter isolada por muito tempo e não sujeita às lógicas de integração de sua região à economia global. O movimento expansivo das economias capitalistas implicou o uso de recursos em diferentes partes do planeta e a integração de economias locais e regionais às oscilações internacionais. A demanda pela construção de obras e projetos que atendam interesses mais gerais da população - ou mais específicos, de setores produtivos - trouxe ao cerne do debate a noção de preservação, transformação, de desenvolvimento e universalização de acessos, entre autodeterminação e liberdade de escolha.

Sobre esse possível conflito, entrevistamos um dos gestores (aqui chamado de Entrevistado 1) responsáveis pela sistematização das propostas das Conferências regionais do PNDH-3, para a conclusão do texto final do Programa, sobre esse suposto conflito entre desenvolvimento e povos tradicionais. Sua avaliação sobre a inclusão desse assunto no texto do Programa é a seguinte:

ñEu acho que tem uma...No Brasil tem umas tensões, uns debates que demonizam muito. Acho que uma visão que é pouco correta é essa. Não é que o desenvolvimento é violador dos direitos humanos. Empreendimentos que são pra avançar nossa estrutura, nossa capacidade produtiva, hoje são vistos como requisitos mínimos para uma vida civilizada. Quando a ONU diz que banda larga é um direito humano, você incorpora a lógica de universalidade de acessos. Os avanços 

possibilidade de aumentar o acesso. E também o seu ônus: há casos em que é a transformação da localidade, de espaços geográficos, não raro, sobretudo no Brasil, onde comunidades com características especificas que muitos querem ver preservadas. O debate sobre isso é muito importante. Nossa legislação é bastante avançada nesse sentido. Você tem discussões feitas entre empreendedores e comunidades afetadas, num processo de negociação e construção, sobre o que pode ser feito. A ideia é buscar qual o senso comum, o meio termo, o que é razoável, o que dá pra fazer e o que adiante tem de trabalhar em medidas compensatórias.

Trata-se de um processo naturalmente desequilibrado, por isso você precisa de transparência, (é ) em que é difícil de ter uma clareza de onde se vai chegar, e chega a uma discussão maniqueísta em que um demoniza um e canoniza o outro.(...) Você tem um processo naturalmente desequilibrado, que precisa saber se foi válido ou não. Essa multiplicidade de interesses, de atores, cria uma constelação de pessoas que se organizam conforme tal. (...) A transparência é uma das melhores medidas para coibir os abusos. (ENTREVISTADO 1, 2014)

Perguntado se enxerga a criação de grandes obras e projetos de infraestrutura como uma forma de opressão do Estado a povos que não necessariamente compartilham da lógica de crescimento econômico das sociedades capitalista, o entrevistado avaliou:

Sobre essa questão de ver o Estado como rolo compressor..Embora eu ache que o Estado já fez por merecer esse tipo de qualificação, eu não entendo que quando o Estado faz investimentos para garantir o acesso a tecnologias que já são dadas, básicas, e que são base para acesso a outras melhorias de vida, você está movendo nessa direção. Questionar essa lógica significa rediscutir o modelo econômico. Você pode até fazer isso, mas isso é uma questão muito mais ampla. Até que você consiga produzir efeito do diálogo [sobre mudança do modelo econômico] você vai ter muitas pessoas que precisam daquele investimento. Aí você entra num debate principiológico e que pode ser absolutamente pertinente. $\mathrm{O}$ debate pertence a essa esfera. Mas (é ) dentro do que você trabalha nesse documento, ele incorpora um debate histórico, os pleitos e anseios daquele momento. Vamos em frente, mas não atropelem os pequenos, a medida aqui é de garantir que haja sempre essa discussão. Acredito que o Programa não segue uma lógica de rolo compressor. Até porque não é uma logica contrária aos interesses da população. Você trabalha para que as pessoas não sejam privadas. Até que seja criada uma outra alternativa, é preciso garantir direitos.ò(ENTREVISTADO 1, 2014) (grifo nosso)

A fala do entrevistado 1 corrobora a noção de que os resultados do desenvolvimento são de propriedade comum, de todos os seres humanos, o que demanda a maximização de seu acesso a todas as pessoas. Novamente, a noção de que há um projeto que requer certa urgência $і ̈$ o projeto, o chamado dos direitos humanos, requer também a disponibilização de funcionamentos importantes para a qualidade de vida de comunidades e de sociedades como um todo. Evidentemente, ouvir as diferentes partes, considerar suas formas de vida social e pontos de vista sobre a realidade, e garantir sua liberdade $\ddot{i}$ o direito de escolha $\ddot{i}$ entre usufruir ou não usufruir de avanços tecnológicos é um direito garantido pelas ações previstas no PNDH-3. 
uma antevisão simplista de algumas ações previstas no Eixo Desenvolvimento e Direitos Humanos, no que diz respeito à erradicação da pobreza em comunidades tradicionais, ao transpor um conceito de pobreza de políticas baseadas no pressuposto monetarista, a algumas populações que vivem sem partilhar desses princípios, o Entrevistado 1 respondeu:

\begin{abstract}
Aqui você fala em igualdade de acesso [referindo-se às ações de erradicação da pobreza em comunidades tradicionais, quilombolas e indígenas] com o mesmo grau, e também de igual oportunidade. Idealmente essas politicas todas são para se atingir um certo patamar. É como aprender a andar de bicicleta. Primeiro você oferece uma bicicleta com rodinhas, para aquele que tem dificuldade, até não precisar mais das rodinhas. Você tem de trabalhar politicas de geração de renda com as ferramentas que tem hoje a sua disposição para que a população possa atingir esse patamar.

A proposta é isso. Constata que um grupo precisa de atenção especifica. Olha, talvez ferramentas possam ajudar essa população também. (é ) Às vezes o que você está precisando construir é uma adaptação de uma ferramenta específica. O problema é não fazer o debate, pois esses direitos você não conseguiria suprir de maneira imediata. (...) Você, trabalhando algum tipo de proteção com melhoria de acessos e garantias, pode produzir um efeito prático. Ao grupo que você disponibiliza ferramentas, você tem de fazer uma escolha de se envolver ou não, e estabelecer relação com os seus princípios, com suas visões de mundo: você propõe o diálogo, e vê se tem adesão. De fato, quem tem que trazer soluções é o Estado. Fica muito mais fácil o Estado trabalhar se há uma proposta. $\mathrm{O}$ debate de direitos humanos é muito pouco propositivo, muito mais reativo, ele propõe muito pouco. O grau de anuência ao principiológico. (ENTREVISTADO 1, 2014)
\end{abstract}

As políticas de geração de renda que possibilitam diferentes acessos (e aqui importa frisar, são diferentes no sentido quantitativo e relativamente à renda e propriedade pessoal, e iguais no sentido de que dez reais, excetuadas as diferenças de preços regionais, possibilitam a qualquer pessoa comprar a mesma quantidade de feijão, por exemplo) em economias capitalistas partem de um ponto de vista liberal, que visa permitir a inclusão pela via da adesão às regras de operação das economias de mercado.

Numa segunda entrevista, indagamos a outra pessoa entrevistada $̈$ aqui chamada de Entrevistado 2 - à época da elaboração do PNDH-3 gestora na Secretaria Especial de Direitos Humanos da Presidência da República, sobre as razões de Amartya Sen ser o único autor nominalmente citado no texto do Programa, e também como ela enxergava essa proposta de erradicação da pobreza em populações tradicionais. As respostas apontaram para a seguinte direção:

Foi uma exigência [referindo-se à citação de Amartya Sen no texto do PNDH-3] do Ministro [Paulo Vannuchi], uma escolha de que a teoria do desenvolvimento como liberdade aparecesse.

Vale lembrar que como slogan do governo anterior era Brasil um pais de todos. A gente sempre teve uma reflexão de que isso se ligava ao fato de que o Brasil era o pais também dos banqueiros e grandes empresários e que o Lula não faria 
om isso e tal. Mas um olhar para o pequeno produtor, que se ombolas, pro desenvolvimento que incluísse essas pessoas era um..Era não, né, ñéò a grande prioridade do governo. Então isso é direitos humanos. O que traz de novidade nesse eixo é dizer que o desenvolvimento como liberdade é direitos humanos. Mas eu vejo isso daqui como reflexo da política que é adotada e das prioridades desses dois governos. Não sei se há reflexão pra além disso.

De fato tem uma ruptura do modelo neoliberal de desenvolvimento que não considerava a redução da desigualdade como elemento fundamental do desenvolvimento do pais. Acho que essa era a grande diretriz desse eixo, de que precisavam ficar muito bem refletidos os direitos humanos e a redução de desigualdades como elementos fundantes da revolução democrática e $\mathrm{o}$ desenvolvimento do pais. Acho que isso ficou muito bem refletido.

A sensação que me dá é que sim é possível ter desenvolvimento do país e crescimento do país com respeito a autodeterminação dos povos, diversidade cultural, território em que se encontram. Um conflito com os próprios povos indígenas, olha o desenvolvimento vai tirar a gente daqui. Então é uma tensão, tem uma aparente contradição mas não é impossível coexistir. As ações tomadas e o diálogo feito (é ) a gente vê que de fato é possível produzir um diálogo e ter um modelo de desenvolvimento de projeto de infraestrutura que respeite as especificidades de cada povo, apesar de ser bastante criticado. (ENTREVISTADO 2, 2014) (grifo nosso)

A partir da fala do Entrevistado 2, é possível compreender que as próprias autoridades gestoras responsáveis pela articulação da agenda de direito ao desenvolvimento em nível nacional partem da premissa teórica do desenvolvimento como liberdade, e consideram as regras de inclusão de renda ( como forma de inclusão nos mercados capitalistas de trabalho e consumo) para promoção de liberdades substantivas e para a superação da pobreza. $O$ forte caráter de inclusão de toda a população pobre na dinâmica dos mercados (afinal, a renda nada mais é que a remuneração dos fatores de produção, cuja utilidade pode ser revertida na demanda da própria produção, pelo consumo) é marca dessa visão: a inclusão pelo consumo.

Outra visão que fica clara na fala do entrevistado aponta para o reconhecimento de interpretações mais gerais de que o governo Lula teria beneficiado também os setores financeiros, mais ricos, e também os grandes empresários, mas que também foi capaz de voltar as atenções a pequenos produtores, a populações quilombolas, a sujeitos historicamente menosprezados da história social brasileira. O mesmo entrevistado aponta como grande diferencial do governo Lula, contrastando-o em comparação com o modelo neoliberal de desenvolvimento, a questão da redução da desigualdade, afirmando-a como elemento fundante de uma ñevolução democrática.ò A marca de inclusão de pobres nos mercados segue a lógica das economias liberais no capitalismo, e é uma característica importante da política neodesenvolvimentista. 
estratégico II de sua diretriz 5, expressa ações voltadas a conferir uma nova roupagem para o Estado brasileiro: estabelece o reforço do papel do Plano Plurianual (PPA) como instrumento de consolidação dos Direitos Humanos e enfrentamento de concentração de renda e riqueza e promoção da inclusão da população de baixa renda, o reforço dos critérios de equidade e prevalência dos direitos humanos como prioritários na avaliação da programação de orçamentária, a instituição de um código de conduta em direitos humanos como critério para contratação e financiamento de empresas, a regulamentação da taxação do imposto sobre grandes fortunas previsto na Constituição e a ampliação de adesão de empresas ao compromisso de responsabilidade social e direitos humanos. (BRASIL, 2009)

Desse conjunto de ações, é possível perceber uma intenção de readequação do Estado ï e das ferramentas disponíveis para a implementação de suas políticas $i ̈$ no sentido de promover direitos humanos. As ações se voltam a um dever de observar e priorizar direitos humanos mesmo nos gastos do Estado, e as questões de concentração de renda e riqueza, e inclusão da população de baixa renda ganham destaque. Essas ações privilegiam a redução de desigualdades que, se não ocorreu de forma sistemática ou aprofundada como a pesquisa de Medeiros, Souza e Castro (2014) indica, foi uma âncora discursiva da proposta neodesenvolvimentista.

Outro ponto que merece destaque é a regulamentação do imposto sobre grandes fortunas. Previsto pelo texto da Constituição de 1988, jamais foi sancionada lei que dispusesse sobre o assunto, e que desafiasse a estrutura desigual da distribuição de riquezas no país. As dificuldades de aprovação de propostas nesse sentido permaneceram evidentes, tendo tal assunto permanecido inalterado nos anos Lula, assim como uma estrutura tributária menos regressiva, o que pode ser explicado pela sensibilidade do tema junto aos setores mais ricos da sociedade brasileira, grande empresariado e detentores dos meios de produção e de grandes fortunas, retardando anda mais reformas de cunho tributário que pudessem enfraquecer a contínuo reforço de desigualdades sistêmicas no país.

Por fim, as ações previstas na diretriz 6 do Eixo Desenvolvimento e Direitos Humanos ocupam-se da questão da sustentabilidade: recuperação de áreas degradadas e de desmatamento, inclusão de direitos ambientais em relatórios de direitos humanos, proteção de direitos ambientais e humanos no Código Florestal, acesso à informação sobre degradação e riscos ambientais e ampliação de base de informações. A preservação ambiental evidentemente não é plenamente realizável em um modo de produção que visa ampliar, 
do uso de recursos para os processos de transformações

industriais: o dilema do crescimento para ampliação desses acessos encontra as restrições evidentes do esgotamento de certos recursos. Por isso mesmo, o conjunto de ações previstas na diretriz 6, apesar de importantes, são um tanto quanto modestas, e se realizadas não garantem que uso predatório de recursos ou a degradação de áreas ambientais deixem de ocorrer no país. Trata-se muito mais de um protocolo consoante aos compromissos do país com uma agenda ambiental que de fato uma preocupação mais profunda com a necessidade de preservação ambiental, não raramente entendida como obstáculo à própria realização do desenvolvimento.

\subsection{Conclusão}

Neste capítulo, observamos que o processo de formulação da agenda política do direito ao desenvolvimento, prevista no Eixo Desenvolvimento e Direitos Humanos do PNDH-3, ao privilegiar uma forma mais aproximada ao modelo de iniciação externa ï com forte participação e mobilização social $̈$ não foi capaz de retirar o caráter neodesenvolvimentista das ações propostas. Pudemos verificar que o governo Lula, contexto de elaboração do Programa, ao colher indicadores otimistas com relação a redução da pobreza e aumento da renda do trabalho, conseguiu criar uma composição de forças sociais diversas, com ganhos evidentes aos setores mais ricos e mais pobres do país, apesar de incapaz de alterar com maior profundidade na estrutura produtiva (permanecendo os ganhos de setores primários da economia) e na desigualdade social brasileira (permanecendo a estrutura tributária desigual e regressiva, e a forte participação social dos setores mais ricos na renda nacional).

Essa correlação de forças, em um ambiente otimista, com ganhos diversificados, garantiu certa hegemonia de acerto do modelo em curso, reforçando a visão de que as reformas empreendidas pelo neodesenvolvimentismo estivessem acertadas à gestão do capitalismo brasileiro, proporcionando ganhos para diferentes setores. Deste modo, as ações previstas na agenda do direito ao desenvolvimento foram adequadas a essa visão.

Temas como a inclusão produtiva, o aumento de renda e a erradicação da pobreza monetária, seguindo uma lógica de expansão de funcionamentos, ganharam destaque no Eixo Desenvolvimento e Direitos Humanos do Programa. A tônica de inclusão liberal, das 
Sen, fica ainda mais clara, assim como a especificação dos contextos de pobreza que se pretende superar, para os quais a avaliação é um instrumento necessário.

As entrevistas realizadas contribuíram para entender o ponto de vista dos gestores responsáveis pela sistematização das propostas, e que participaram efetivamente de encontros em nível regional e nacional para a conclusão do texto do Programa. Tais pontos de vista puderam revelar ainda mais os projetos em disputa na formulação da agenda de direitos humanos ao desenvolvimento do PNDH-3, com predomínio da convenção neodesenvolvimentista em seu texto.

\section{CONCLUSÃO. CONSIDERAÇÕES FINAIS}


Lula (2003-2010), foi o resultado de uma certa mixagem - ou composição pragmática ï dos alicerces de políticas econômicas monetaristas implementadas em períodos de maior vigor de ajustamentos neoliberais, e de políticas de caráter mais ativista do Estado, com a participação e fomento de atividades produtivas, expansão do crédito por meio de bancos públicos e incentivo à indústria e agricultura, redesenhando algumas medidas já experienciadas no período de modernização capitalista e industrial, com base no desenvolvimentismo de matriz estruturalista.

Essa mixagem de políticas produziu uma forma de gestão do capitalismo brasileiro que, apesar de incapaz de registrar alteração no modelo de crescimento instável de baixo dinamismo observado nas décadas de 1990 e 2000 ï oscilando entre significativas expansões do Produto Interno Bruto em alguns anos, e fraco desempenho do mesmo crescimento em outros; foi ao mesmo tempo capaz de resgatar certo ativismo estatal, universalizando o acesso a algumas políticas públicas, de expandir a renda e ganhos salariais da classe trabalhadora, além de promover políticas de transferência de renda indispensáveis para a erradicação da pobreza extrema, sob o ponto de vista monetário.

Se por um lado o neodesenvolvimentismo foi incapaz de produzir alterações de fundo no cenário das desigualdades sociais brasileiras, com reformas mais profundas do sistema tributário ou que de fato transferissem renda dos mais ricos aos mais pobres, por outro lado conseguiu promover maiores acessos por meio de políticas de transferência de renda e universalização de políticas públicas. Sob essa perspectiva, o crescimento econômico tem uma finalidade clara, de garantir a capacidade do Estado de financiar políticas para promoção de bem-estar.

O dilema deste modelo pode ser traduzido na permanente lógica de recondução ou realocação do crescimento econômico (que permanece como máxima perseguida pelo neodesenvolvimentismo), com o intuito de compensar o crescimento econômico dinâmico do período de modernização industrial no século XX, marcado por forte concentração de renda. Essa contemporaneidade do discurso do crescimento econômico esbarra em desafios concretos da própria lógica de funcionamento do capitalismo: será possível crescer em um contexto de recursos naturais limitados? Afinal, qual a finalidade do crescimento econômico?

Ainda que a expansão produtiva pretenda promover a universalização de acessos a funcionamentos úteis ou relevantes em economias de mercado $̈$ conforme propõe Amartya Sen, os dilemas da economia brasileira são enormes. A baixa capacidade de investimento do 

de produção ï e consequentemente da renda por meio deles gerada ï e a sujeição aos fluxos, rupturas e continuidades do sistema global de produção e trocas tornam o projeto de crescimento com a finalidade de expandir a garantia de acessos cada vez mais dificultada.

O dilema desse projeto está em sua natureza constitutiva. O crescimento como imperativo não seguirá seu fluxo constante, uma vez que há uma tendência à diminuição do crescimento demográfico nacional, e um consequente desaquecimento de demanda. E mesmo que se criem novos desejos e se objetive uma expansão constante, é impossível assegurar a permanência de crescimento econômico em um planeta com recursos naturais limitados. A correção dos desvios de um projeto tão concentrador de renda como foi a modernização capitalista brasileira por meio da fórmula de acessos marginais, garantidos à base da pirâmide social por meio da expansão da produção ï que atualmente já sinaliza uma importante desaceleração ï e manutenção dos pressupostos macroeconômicos é inviável.

Esses dilemas são importantes para a construção de um projeto de desenvolvimento que vá além do ganho marginal por setores mais pobres, que considere a distribuição mais profunda da renda nacional, da riqueza produzida (e existente) no país. Isto depende não apenas de um resgate das capacidades estatais, fortalecidas para criar políticas de universalização de acessos e desobstrução de amarras e impedimentos que inviabilizam o bem-estar das pessoas, conforme os diferentes contextos e necessidades transitivas. Depende também de esforços no sentido de reverter as já existentes desigualdades na produção da renda, para a qual a uma política tributária pode ser um importante instrumento.

Conforme pudemos observar, a agenda do direito ao desenvolvimento, no contexto de vigência do neodesenvolvimentismo, foi construída de forma contida, encerrada nas próprias exigências contextuais, sem apresentar grandes inflexões no que diz respeito à preservação ambiental, à própria superação da pobreza não monetária e em questões tributárias ï com exceção da proposta de regulamentação do imposto sobre grandes fortunas ï sem previsão de alteração da estrutura de tributação como um todo do país, para citarmos alguns exemplos.

A agenda política do direito humano ao desenvolvimento, se quiser apontar em direção à afirmação concreta do desenvolvimento como liberdade, afastando de vez as privações objetivas que impedem uma vida de qualidade das pessoas, e que garanta os processos que permitem liberdade de ações e decisões, terá de promover inflexões de fundo, voltadas tanto à alteração da estrutura produtiva do país, fazendo com que a apropriação dos resultados do crescimento econômicos sejam maiores, beneficiando o maior número de pessoas quanto 
agroexportadores), que frequentemente não demonstram com expressividade o efeito cascata (trickle down) de multiplicação de seus ganhos a mais pessoas. Terá também de desconcentrar a riqueza nacional, de modo a permitir a superação mais eficiente e melhor alocada dos ganhos de diferentes setores da população.

Tais tarefas, por poucas que pareçam, são desafios imensos, sujeitos às dificuldades de governança e exercício do poder. Elas apontam caminhos para investigações futuras, que demandam diagnósticos mais precisos sobre a dificuldade de implementação de uma agenda política de reformas mais profundas, capazes de distribuir de fato a renda nacional. É por meio delas que poderemos ver com maior vigor uma concretização do direito ao desenvolvimento que, em última análise, é a concretização do mais humano dos direitos. O direito ao desenvolvimento diz respeito, enfim, a garantir o acesso, as escolhas, a participação dos processos de decisão, e a evitar privações objetivas nas existências de cada ser humano: trata-se, afinal, do direito a ter direitos.

\section{REFERÊNCIAS}

ABREU, Kátia. Direitos humanos ou gato por lebre?. In: Folha de S. Paulo, Opinião, 12 de 
ADORNO, Sérgio. História e desventura: o $3^{\circ}$. Programa Nacional de Direitos Humanos. Novos Estudos: CEBRAP. São Paulo, n. 86, março de 2010. Disponível em: $<$ http://www.scielo.br/scielo.php?script=sci_arttext\&pid=S0101-33002010000100001\&lng= en\&nrm=iso>. Data de acesso: 30 de setembro de 2014.

AFSA et. al. Survey of Existing Approaches to Measuring Socio-Economic Progress. Pesquisa preparada para a Comissão de Medição de Desempenho Econômico e Progresso Social. Instituto Nacional de Estudos Estatísticos e Econômicos da França. Organização para a Cooperação e Desenvolvimento Econômico ï OCDE, 2008. Disponível em: $<$ http://www.stiglitz-senfitoussi.fr/documents/Survey_of_Existing_Approaches_to_Measuring _Socio-Economic_Progress.pdf>. Data de acesso: 11 de maio de 2014.

AMITRANO, Claudio Roberto. O modelo de crescimento da economia brasileira no período recente: condicionantes, características e limites. In: CARNEIRO, Ricardo (org.). A supremacia dos mercados e a política econômica do governo Lula. São Paulo: Ed. Unesp, 2006.

ANDERSON, Perry. Balanço do neoliberalismo. In: SADER, Emir et. GENTILI, Pablo (orgs.) Pós-neoliberalismo: as políticas sociais e o Estado democrático. Rio de Janeiro: Paz e Terra, 1995, pp. 09-23.

ARBIX, Glauco et. MARTIN, Scott B. Beyond developmentalism and market fundamentalism in Brazil: inclusionary state activism without statism. Workshop on States Development and Global Governance. In: Anais de Global Legal Studies Center and the Center for World Affairs and the Global Economy (WAGE). Universidade MadisonWisconsin, Estados Unidos, 2010. Disponível em: <http://keats.kcl.ac.uk/pluginfile.php 1734782/mod_resource/content/1/Arbix\%20\%20Martin\%20Liberal\%20neodevelopmentalism . Pdf $>$

BAN, Cornell. Brazil liberal neodevelopmentalism: new paradigm or edited ortodoxy? Review of international political economy. V. 20, Ed. 2, abril 2013, pp. 298-331. Routledge, Reino Unido.

BANCO MUNDIAL. Indicadores do desenvolvimento mundial (2013). Disponível em: $<$ http://www.google.com/publicdata/explore?ds=d5bncppjof8f9_\&hl=pt-PT\&dl=pt-PT\#!ctyp_

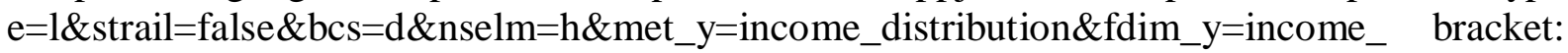
$7 \&$ scale_y=lin\&ind_y $=$ false\&rdim $=$ country\&idim $=$ country:BRA\&ifdim=country\&hl=pt_PT $\& d l=p t \_P T \& i n d=f a l s e>$. Data de acesso: 26 de julho de 2014.

BATISTA, Paulo Nogueira. O Consenso de Washington: a visão neoliberal dos problemas latino-americanos. In: LIMA SOBRINHO, Barbosa. Em defesa do interesse nacional: desinformação e alienação do patrimônio público. Rio de Janeiro: Paz e Terra, 1994.

BIELSCHOWSKY, Ricardo. O desenvolvimentismo do pós-guerra até meados dos anos 


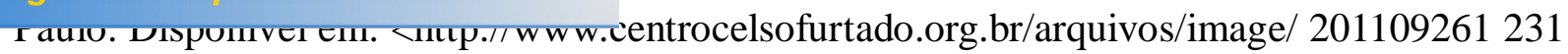
420.LivroCAIXA_C_0_15.pdf>

BOITO JR., Armando. As bases políticas do neodesenvolvimentismo. São Paulo: Fundação Getúlio Vargas, 2003.

BRASIL. Fundação Instituto Brasileiro de Geografia e Estatística. Pesquisa Mensal de emprego. 2002.

Pesquisa Nacional por Amostra de Domicílios ï PNAD. 2003-2011.

. Produto Interno Bruto. Variação em Volume (1995-2012). SCN 53. Disponível em: <http://seriesestatisticas.ibge.gov.br/series.aspx $?$ no=1\&op=1\&vcodigo=SCN53\&t=produtointerno-brutobrvariacao-volume>. Data de acesso: 22 de abril de 2014.

. Anuário estatístico do Brasil. 1993.

BRASIL. Ipeadata. Base de dados macroeconômicos, financeiros e regionais do Brasil mantida pelo Ipea. Disponível em: <http://www.ipeadata.gov.br/>. Data de acesso: 08 de setembro de 2014.

BRASIL. Tribunal Superior Eleitoral (TSE). Eleições 2002. Prestação de contas Eleitorais. Disponível em: <http://www.tse.jus.br/eleicoes/eleicoes-anteriores/eleicoes-2002/contas-decampanha-eleitoral-eleicoes-2002>. Data de acesso: 05 de abril de 2014.

BRASIL. Programa Nacional de Direitos Humanos 2. 2002. Disponível em: <http://dhnet.org.br/dados/pp/edh/pndh_2_integral.pdf>. Data de acesso: 29 de setembro de 2014.

. Programa Nacional de Direitos Humanos 3. 2009. Disponivel em: $\overline{<\mathrm{http}: / / w w w . s d h . g o v . b r / a s s u n t o s / d i r e i t o-p a r a-t o d o s / p r o g r a m a s / p d f s / p r o g r a m a-n a c i o n a l-d e-~}$ direitos-humanos-pndh-3>. Data de acesso: 5 de março de 2014.

. Subsídio para revisão e atualização do programa nacional de direitos humanos ï PNDH. Secretaria Especial de Direitos Humanos da Presidência da República. Brasília: 2010.

- Ministério do Trabalho e Emprego. Relação Anual de Informações Sociais ï RAIS. 2010. Disponível em: <http://www3.mte.gov.br/rais/2010/>. Data de acesso: 14 de outubro de 2014.

- Decreto $\mathrm{n}^{\mathrm{o}}$. 7.177, de 12 de maio de 2010. Disponível em: acesso: 7 de outubro de 2014 .

. Banco Central do Brasil. Série histórica do balanço de pagamentos. Disponível em: <http://www.bcb.gov.br/?SERIEBALPAG>. Data de acesso: 12 de setembro de 2014.

Banco Central do Brasil. Histórico das taxas de juros. Disponível em: 
ROS>. Data de acesso: 23 de outubro de 2014.

BRESSER-PEREIRA, Luís Carlos. Desenvolvimento e Crise no Brasil: História, Economia e Política de Getúlio Vargas a Lula. São Paulo: Brasiliense, 2003.

Não consigo fazer diferença entre as ideias de Marina e Aécio: entrevista. [25 setembro de 2014]. São Paulo: Blog Socialista Morena. Disponível em: $<$ http://socialistamorena.cartacapital.com.br/bresser-pereira-nao-consigo-fazer-diferencaentre-as-ideias-de-marina-e-as-de-aecio/>. Data de acesso: 15 de outubro de 2014.

CALLEGARI, José Carlos. Desenvolvimento econômico, direito do trabalho e direitos sociais. Uma análise das convenções da Organização Internacional do Trabalho. In: PIOVESAN, Flávia et. SOARES, Inês Virgínia Prado.(orgs). In: Direito ao desenvolvimento. Belo Horizonte: Ed. Fórum, 2010.

CARDOSO, Fernando Henrique. O regime político brasileiro. In: Estudos Cebrap, $\mathrm{n}^{\mathrm{o}}$ 2, out. 1972, pp. 84-118.

. Mãos à obra. Programa de governo, 1994.

Notas sobre a reforma do Estado. Novos Estudos Cebrap nº. 50: 1998, p. 5-12.

COUTINHO, Carlos Nelson. Gramsci. Um estudo sobre seu pensamento político. Rio de Janeiro: Ed. Civilização Brasileira, edição revisada e ampliada, 1999.

CUNHA, Antônio Geraldo da. Dicionário etimológico da língua portuguesa. 4. ed. Rio de Janeiro: Lexikon, 2010.

CURADO, Marcelo. Uma avaliação da economia brasileira no governo Lula. In: Economia \& Tecnologia. Curitiba, Ano 07, volume Especial. 2011. Disponível em: <http://www.economiaetecnologia.ufpr.br/revista/Especial\%20Capa/Marcelo\%20Curado.pdf> . Data de acesso: 20de setembro de 2014.

DIAS, Reginaldo Benedito. Ação popular marxista-leninista e a formação do PT. Fundação Perseu Abramo. n. 3, Ano 3, 2009. Disponível em: <http://www.fpabramo.org.br/sites/default/files/3-ReginaldoP3.pdf $>$. Data de acesso: $20 \mathrm{de}$ janeiro de 2014.

DINIZ, Eli. Depois do neoliberalismo. Rediscutindo a articulação Estado e desenvolvimento no novo milênio. In: BOSCHI, Renato (org.) Variedades de capitalismo, política e desenvolvimento na América Latina. Belo Horizonte: Ed. UFMG, 2011.

DYE, Thomas. Understanding public policy. New Jersey: Prentice-Hall, 1972.

EPSTEIN, Lee et. KING, Gary. Pesquisa empírica em direito: as regras de inferência. São Paulo: Fundação FGV, 2013. Disponível em: <http://bibliotecadigital.fgv.br/dspace/handle/ 10438/11444> . Data de acesso: 05 outubro de 2014.

ERBER, Fábio Stefano. As convenções de desenvolvimento no governo Lula: um ensaio de 
nia Política, v. 31, nº 1 (121), 2011, pp. 31-55.

EVANS, Peter. Autonomia e parceria: Estados e transformação industrial. Rio de Janeiro: Ed. UFRJ, 2004.

FILGUEIRAS, Luiz. O neoliberalismo no Brasil: estrutura, dinâmica e ajuste do modelo econômico. p. 179-206. In: BASUALDO, Eduardo M.; ARCEO, Enrique (orgs). Neoliberalismo y sectores dominantes. Tendencias globales y experiencias nacionales. CLACSO, Buenos Aires. Agosto de 2006.

FIORI, José Luis. 60 lições dos 90: uma década de neoliberalismo. 2. Ed. Rio de Janeiro: Record, 2002.

FRIEDMAN, Milton. Capitalismo e liberdade. Coleção os economistas. São Paulo: Ed. Abril, 1984.

FUKUDA-PARR, Sakiko et. al. Assessing state compliance with obligations to fulfill economic and social rights $\ddot{i}$ a methodology and application to the states of Brazil. In: PIOVESAN, Flavia et. SOARES, Inês Virgínia Prado. (org.). Direito ao desenvolvimento. Belo Horizonte: Fórum, 2010.

FUNDAÇÃO GETÚLIO VARGAS e IBGE - Instituto Brasileiro de Geografia e Estatística. Centro de Contas Nacionais - diversas publicações, período 1947 a 1989; IBGE. Diretoria de Pesquisas. Coordenação de Contas Nacionais. Disponível em: <http://seriesestatisticas. ibge.gov.br/series.asp $\mathrm{x}$.no $=1 \& \mathrm{op}=1 \&$ vcodigo $=\mathrm{SCN} 52 \& \mathrm{t}=$ produto-interno-bruto-br-valorescorrentes>. Data de acesso: 06 abril de 2014.

FURTADO, Celso. Economia do desenvolvimento. Curso ministrado na PUC-SP em 1975. Rio de Janeiro: Contraponto e Centro Internacional Celso Furtado de Políticas para o Desenvolvimento, 2008.

GOMIDE, Alexandre de Ávila et. PIRES, Roberto Rocha C. Capacidades estatais e democracia: a abordagem dos arranjos institucionais para a análise de políticas públicas. In: GOMIDE, Alexandre de Ávila et. PIRES, Roberto Rocha C (ed.). Capacidades estatais e democracia: arranjos institucionais de políticas públicas. Brasília: Ipea, 2014.

GIAMBIAGI, Fábio et. al. Economia brasileira contemporânea (1945-2004). Rio de Janeiro: Elsevier, 2005.

GREMAUD, Amaury Patrick et. al. Economia brasileira contemporânea. 7. ed. São Paulo: Atlas, 2011.

HARVEY, David. O enigma do capital e as crises do capitalismo. Trad. de João Alexandre Peschanski. São Paulo: Ed. Boitempo, 2011.

HOBSBAWM, Eric. A era do capital, 1848-1857. Trad. de Luciano Costa Neto. 15. ed. Rio de Janeiro: Paz e Terra, 2011.

HOWLETT, Michael at. al. Política pública. Seus ciclos e subsistemas. Uma abordagem integral. Trad. de Francisco G. HeIbidemann. Rio de Janeiro: Elsevier, 2013. 


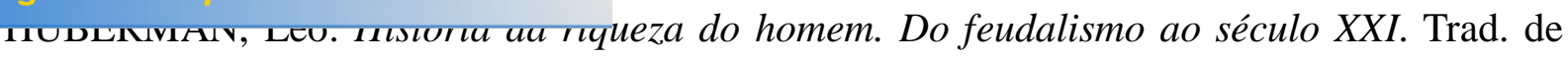
Waltensir Dutra. 22. Ed. Rio de Janeiro: LTC, 2010.

IANNI, Octavio. A sociedade global. Rio de Janeiro: Civilização Brasileira, 1995.

LE GOFF, Jacques. A história nova. Trad. de Eduardo Brandão. 5. ed. São Paulo: Martins Fontes, 2005.

LOURENÇO DE ALMEIDA, Wellington. Direitos humanos no Brasil (1988-1998): um desafio à consolidação democrática. 2002. 321 páginas. Tese (Doutorado em Ciência Política) ï Departamento de Ciência Política da Faculdade de Filosofia, Letras e Ciências Humanas da Universidade de São Paulo. São Paulo, 2002.

LULA DA SILVA, Luiz Inácio. Discurso de posse em $1^{\circ}$ de janeiro de 2003. Disponível em: <http://www.biblioteca.presidencia.gov.br/ex-presidentes/luiz-inacio-lula-da-silva/discursosde-poss e/discurso-de-posse-1o-mandato/view >

. Discurso de posse em $1^{\circ}$ de janeiro de 2007. Disponível em: <http://www.biblioteca.presidencia.gov.br/ex-presidentes/luiz-inacio-lula-da-silva/discursosde-poss e/discurso-de-posse-2o-mandato/view>

- Carta ao povo brasileiro. São Paulo, 2002. Disponível em: <http://www.iisg.nl/collections/carta_ao_povo_brasileiro.pdf $>$. Data de acesso: 21 de janeiro de 2014.

MAHONEY, James. Explaining political development in Central America. In the legacies of liberalism: path dependence and political regimes in Central America. Baltimore: The Johns Hopkins University Press, 2002, pp. 3-28.

MANKIW, Nicholas Gregory. Introdução à economia. Trad. de Allan Vidigal Hastings. São Paulo: Cengage Learning, 2009.

MANTEGA, Guido et. MORAES, Maria. Acumulação Monopolista e Crises no Brasil. 2a ed. Rio de Janeiro: Paz e Terra, 1991.

MEDEIROS, C. et alii. Relações de trabalho, educação e mecanismos de proteção social. Série Seminários, n. 15/93, Ipea, jul. 1993.

MEDEIROS, Marcelo; SOUZA, Pedro HGF; CASTRO, Fábio Ávila. A estabilidade da desigualdade de renda no Brasil, 2006 a 2012: estimativa com dados do imposto de renda e pesquisas domiciliares. 9 de setembro de 2014. Disponível em: <http://papers.ssrn.com/sol3/papers.cfm?abstract_id=2493877>. Data de acesso: 23 de outubro de 2014.

NWAUCHE, E.S.; NWOBIKE, J.C. Implementação do direito ao desenvolvimento. In: Sur Revista internacional de direitos humanos. v. 2., n. 2, São Paulo: 2005, pp. 96-117.

ORGANIZAÇÃO DAS NAÇÕES UNIDAS. Declaração sobre o direito ao desenvolvimento de 1986. Disponível em: <http://www.direitoshumanos.usp.br/index.php/Direito-ao- 
PARTIDO DOS TRABALHADORES. Resoluções de encontros e congressos, 1979-1998. São Paulo: Ed. Fundação Perseu Abramo, 1998.

PAULANI, Leda. A hegemonia neoliberal. Palestra realizada em 27 de agosto de 2010 no Instituto Celso Furtado. Disponível em: <http://www.centrocelsofurtado.org.br/arquivos/ image/201109261233410.Livro CAIXA_C_0_35.pdf>

. Brasil delivery: servidão financeira e estado de emergência econômico. São Paulo: Boitempo, 2008.

PIANIGIANI, Pietro Ottorino. Vocabolario etimologico della lingua italiana. Florença, 1907. Disponível em: <http://www.etimo.it/?pag=hom>. Data de acesso: 11 de maio de 2014.

PIERSON, Paul. Positive feedback and path dependence. Politics in time: history, institutions and social analysis. Princeton: Princeton University Press, 2004, pp. 17-53.

PIKETTY, Thomas. Capital in the twenty-first century. Trad. para o inglês de Arthur Goldhammer. Cambridge: Harvard University Press, 2014.

PIOVESAN, Flávia. Direito ao desenvolvimento: desafios contemporâneos. In: PIOVESAN, Flávia et. SOARES, Inês Virgínia Prado.(orgs). Direito ao desenvolvimento. Belo Horizonte: Ed. Fórum, 2010.

POCHMANN, Marcio. O mito da grande classe média: capitalismo e estrutura social. São Paulo: Boitempo, 2014.

PRESTON, Peter. Development theory: an introduction to the analysis of complex change. Indianapolis: Wiley-Blackwell, 1996.

PROGRAMA DAS NAÇÕES UNIDAS PARA O DESENVOLVIMENTO (PNUD). Human development report 2013. The rise of the south: human progress in a diverse world. Disponível em: <http://hdr.undp.org/sites/default/files/reports/14/hdr2013_en_complete.pdf>. Data de acesso: 19 mai 2014.

REIS, José Carlos. História e teoria. Historicismo, Modernidade, Temporalidade e Verdade. Rio de Janeiro: FGV, 2007.

RIPLEY, Randall. Stages of the policy process. In: MCCOOL, Daniel C. Public policies theories, models, and concepts: an anthology. New Jersey: Prentice Hall, 1995.

ROCHAU, August Ludwig von. Grundsätze der Realpolitik angewendet auf die staatlichen Zustände Deutschlands. Stuttgart: Verlag von Karl Göpel, 1853. 
políticas públicas: conceitos básicos. In: RUA, Maria das

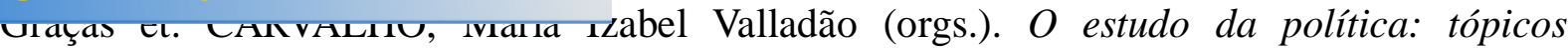
selecionados. Brasília: Paralelo 15, 1998.

SACHS, Ignacy. Desenvolvimento: includente, sustentável, sustentado. Rio de Janeiro: Garamond, 2008.

SACHS, Jeffrey. O fim da pobreza: como acabar com a miséria mundial nos próximos 20 anos. Trad. de Pedro Maia Soares. São Paulo: Cia. das Letras, 2011.

SEN, Amartya. Social choice, welfare and measurement. Oxford: Blackwell, 1982. Harvard University Press, 1999.

SEN, Amartya. Sobre ética e economia. Trad. de Laura Teixeira Motta. São Paulo: Cia das Letras, 1999.

Desenvolvimento como liberdade. Trad. de Laura Teixeira Motta. São Paulo: Companhia das Letras, 2009.

Desigualdade reexaminada. 3. ed. Trad. de Ricardo Doninelli Mendes. Rio de Janeiro: Record, 2012.

. A ideia de justiça. Trad. de Denise Bottmann e Ricado Doninelli Mendes. São Paulo: Companhia das Letras, 2013.

SICSÚ, João. Introdução. In: SICSÚ, João; PAULA, Luiz Fernando e Michel, Renaut. (orgs.) Novo-desenvolvimentismo: um projeto nacional de crescimento com equidade social. Rio de Janeiro: Fundação Konrad Adenauer, 2005.

SILVA, Leandro Ribeiro. Os ciclos desenvolvimentistas brasileiros (1930-2010): do nacional desenvolvimentismo ao novo desenvolvimentismo. Tese de Doutoramento (Doutorado em Ciências Sociais) na Unicamp. Campinas: 2013.

SINGER, André. Os sentidos do lulismo. Reforma gradual e pacto conservador. São Paulo: Companhia das Letras, 2012.

SKIDMORE, Thomas. Brasil: de Getúlio a Castello(1930-64). Trad. de Berilo Vargas. São Paulo: Cia das Letras, 2010.

SOUZA, Jessé. A ralé brasileira. Belo Horizonte: Ed. UFMG, 2011.

TEIXEIRA, Rodrigo Alves et PINTO, Eduardo Costa. A economia política dos governos FHC, Lula e Dilma.: dominância financeira, bloco no poder e desenvolvimento econômico. In: Economia e sociedade, Campinas, v. 21, Número Especial, p. 909 ï 941, dez 2012.

THELEN, Kathleen. Historical institutionalism in comparative politics. Annual review of political science. Los Angeles: 1999, pp. 369-404.

VEBLEN, Thorstein. A teoria da classe ociosa: um estudo econômico das instituições. São Paulo: Abril Cultural, 1983. 
WALLERSTEIN, Immanuel. Capitalismo histórico e civilização capitalista. Trad. de Renato Aguiar. Rio de Janeiro: Contraponto, 2001.

Rio de Janeiro: Editora Revan, 2002.

O fim do mundo como o concebemos: ciência social para o século XXI.

\section{Programa de Televisão}

ENTREVISTA COM IVES GANDRA SOBRE O PNDH-3, 2009. Programa do Jô. São Paulo: Rede Globo, 27 de outubro de 2009.

\section{APÊNDICES}


O tema ñdesenvolvimentoò tem sido amplamente debatido por ser um conceito complexo e multidisciplinar. Não existe modelo único e preestabelecido de desenvolvimento, porém, pressupõe-se que ele deva garantir a livre determinação dos povos, o reconhecimento de soberania sobre seus recursos e riquezas naturais, respeito pleno à sua identidade cultural e a busca de equidade na distribuição das riquezas.

Durante muitos anos, o crescimento econômico, medido pela variação anual do Produto Interno Bruto (PIB), foi usado como indicador relevante para medir o avanço de um país. Acreditava-se que, uma vez garantido o aumento de bens e serviços, sua distribuição ocorreria de forma a satisfazer as necessidades de todas as pessoas. Constatou-se, porém, que, embora importante, o crescimento do PIB não é suficiente para causar, automaticamente, melhoria do bem-estar para todas as camadas sociais. Por isso, o conceito de desenvolvimento foi adotado por ser mais abrangente e refletir, de fato, melhorias nas condições de vida dos indivíduos.

A teoria predominante de desenvolvimento econômico o define como um processo que faz aumentar as possibilidades de acesso das pessoas a bens e serviços, propiciadas pela expansão da capacidade e do âmbito das atividades econômicas. O desenvolvimento seria medida qualitativa do progresso da economia de um país, refletindo transições de estágios mais baixos para estágios mais altos, por meio da adoção de novas tecnologias que permitem e favorecem essa transição. Cresce nos últimos anos a assimilação das ideias desenvolvidas por Amartya Sen, que abordam o desenvolvimento como liberdade e seus resultados centrados no bem estar social e, por conseguinte, nos direitos do ser humano.

São essenciais para o desenvolvimento as liberdades e os direitos básicos como alimentação, saúde e educação. As privações das liberdades não são apenas resultantes da escassez de recursos, mas sim das desigualdades inerentes aos mecanismos de distribuição, da ausência de serviços públicos e de assistência do Estado para a expansão das escolhas individuais. Este conceito de desenvolvimento reconhece seu caráter pluralista e a tese de que a expansão das liberdades não representa somente um fim, mas também o meio para seu alcance. Em consequência, a sociedade deve pactuar as políticas sociais e os direitos coletivos de acesso e uso dos recursos. A partir daí, a medição de um índice de desenvolvimento humano veio substituir a medição de aumento do PIB, uma vez que o Índice de Desenvolvimento Humano (IDH) combina a riqueza per capita dada pelo PIB aos aspectos 
ermitindo, pela primeira vez, uma avaliação de aspectos sociais não mensurados pelos padrões econométricos.

No caso do Brasil, por muitos anos o crescimento econômico não levou à distribuição justa de renda eriqueza, mantendo-se elevados índices de desigualdade. As ações de Estado voltadas para a conquista da igualdade socioeconômica requerem ainda políticas permanentes, de longa duração, para que se verifique a plena proteção e promoção dos Direitos Humanos. É necessário que o modelo de desenvolvimento econômico tenha a preocupação de aperfeiçoar os mecanismos de distribuição de renda e de oportunidades para todos os brasileiros, bem como incorpore os valores de preservação ambiental. Os debates sobre as mudanças climáticas e o aquecimento global, gerados pela preocupação com a maneira com que os países vêm explorando os recursos naturais e direcionando o progresso civilizatório, está na agenda do dia. Esta discussão coloca em questão os investimentos em infraestrutura e modelos de desenvolvimento econômico na área rural, baseados, em grande parte, no agronegócio, sem a preocupação com a potencial violação dos direitos de pequenos e médios agricultores e das populações tradicionais.

O desenvolvimento pode ser garantido se as pessoas forem protagonistas do processo, pressupondo a garantia de acesso de todos os indivíduos aos direitos econômicos, sociais, culturais e ambientais, e incorporando a preocupação com a preservação e a sustentabilidade como eixos estruturantes de proposta renovada de progresso. Esses direitos têm como foco a distribuição da riqueza, dos bens e serviços.

Todo esse debate traz desafios para a conceituação sobre os Direitos Humanos no sentido de incorporar o desenvolvimento como exigência fundamental. A perspectiva dos Direitos Humanos contribui para redimensionar o desenvolvimento. Motiva a passar da consideração de problemas individuais a questões de interesse comum, de bem-estar coletivo, o que alude novamente o Estado e o chama à corresponsabilidade social e à solidariedade.

Ressaltamos que a noção de desenvolvimento está sendo amadurecida como parte de um debate em curso na sociedade e no governo, incorporando a relação entre os direitos econômicos, sociais, culturais e ambientais, buscando garantia do acesso ao trabalho, à saúde, à educação, à alimentação, à vida cultural, à moradia adequada, à previdência, à assistência social e a um meio ambiente sustentável. A inclusão do tema Desenvolvimento e Direitos Humanos na $11^{\mathrm{a}}$ Conferência Nacional reforçou as estratégias governamentais em sua proposta de desenvolvimento. 
para políticas públicas de redução das desigualdades sociais concretizadas por meio de ações de transferência de renda, incentivo à economia solidária e ao cooperativismo, à expansão da reforma agrária, ao fomento da aquicultura, da pesca e do extrativismo e da promoção do turismo sustentável.

O PNDH-3 inova ao incorporar o meio ambiente saudável e as cidades sustentáveis como DireitosHumanos, propõe a inclusão do item ñdireitos ambientaisò nos relatórios de monitoramento sobre Direitos Humanos e do item ñDireitos Humanosò nos relatórios ambientais, assim como fomenta pesquisas de tecnologias socialmente inclusivas.

Nos projetos e empreendimentos com grande impacto socioambiental, o PNDH-3 garante a participação efetiva das populações atingidas, assim como prevê ações mitigatórias e compensatórias. Considera fundamental fiscalizar o respeito aos Direitos Humanos nos projetos implementados pelas empresas transnacionais, bem como seus impactos na manipulação das políticas de desenvolvimento. Nesse sentido, avalia como importante mensurar o impacto da biotecnologia aplicada aos alimentos, da nanotecnologia, dos poluentes orgânicos persistentes, metais pesados e outros poluentes inorgânicos em relação aos Direitos Humanos.

Alcançar o desenvolvimento com Direitos Humanos é capacitar as pessoas e as comunidades a exercerem a cidadania, com direitos e responsabilidades. É incorporar, nos projetos, a própria população brasileira, por meio de participação ativa nas decisões que afetam diretamente suas vidas. É assegurar a transparência dos grandes projetos de desenvolvimento econômico e mecanismos de compensação para a garantia dos Direitos Humanos das populações diretamente atingidas.

Por fim, este Programa reforça o papel da equidade no Plano Plurianual (PPA), como instrumento degarantia de priorização orçamentária de programas sociais.

\section{Diretriz 4:}

Efetivação de modelo de desenvolvimento sustentável, com inclusão social e econômica, ambientalmente equilibrado e tecnologicamente responsável, cultural e regionalmente diverso, participativo e não discriminatório.

\section{Objetivo estratégico I:}

Implementação de políticas públicas de desenvolvimento com inclusão social. 
a) Ampliar e fortalecer as políticas de desenvolvimento social e de combate à fome, visando a inclusão e a promoção da cidadania, garantindo a segurança alimentar e nutricional, renda mínima e assistência integral às famílias.

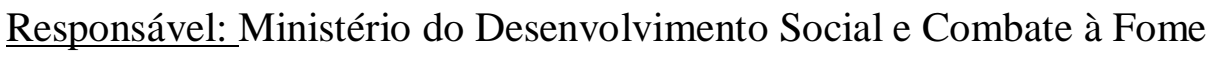

b) Expandir políticas públicas de geração e transferência de renda para erradicação da extrema pobreza e redução da pobreza.

Responsável: Ministério do Desenvolvimento Social e Combate à Fome

Parceiros: Ministério do Desenvolvimento Agrário; Ministério do Trabalho e Emprego; Ministério do Planejamento, Orçamento e Gestão; Ministério da Fazenda

c) Apoiar projetos de desenvolvimento sustentável local para redução das desigualdades inter e intrarregionais e o aumento da autonomia e sustentabilidade de espaços sub-regionais.

Responsáveis: Secretaria Especial dos Direitos Humanos da Presidência da República; Ministério do Desenvolvimento Agrário

Parceiros: Ministério do Desenvolvimento Social e Combate à Fome; Ministério do Trabalho e Emprego; Ministério do Meio Ambiente; Ministério da Integração Nacional; Ministério da Cultura; Ministério da Pesca e Aquicultura; Ministério do Desenvolvimento, Indústria e Comércio Exterior

d) Avançar na implantação da reforma agrária, como forma de inclusão social e acesso aos direitos básicos, de forma articulada com as políticas de saúde, educação, meio ambiente e fomento à produção alimentar.

Responsável: Ministério do Desenvolvimento Agrário

Parceiros:Ministério do Desenvolvimento Social e Combate à Fome; Instituto Nacional de Colonização e Reforma Agrária (INCRA); Ministério da Saúde; Ministério da Educação; Ministério do Meio Ambiente; Empresa Brasileira de Pesquisa Agropecuária (Embrapa)

e) Incentivar as políticas públicas de economia solidária, de cooperativismo e associativismo e de fomento a pequenas e micro empresas.

Responsáveis:Ministério do Trabalho e Emprego; Ministério do Desenvolvimento Agrário; Ministério das Cidades; Ministério do Desenvolvimento Social e Combate à Fome

Parceiros:Ministério do Desenvolvimento, Indústria e Comércio Exterior; Ministério da Pesca 
mbiente; Ministério da Cultura

f) Fortalecer políticas públicas de apoio ao extrativismo e ao manejo florestal comunitário ambientalmente sustentáveis.

Responsáveis:Ministério do Meio Ambiente; Ministério do Desenvolvimento Agrário; Ministério do Desenvolvimento, Indústria e Comércio Exterior

Parceiro:Instituto Nacional de Metrologia, Normalização e Qualidade Industrial (Inmetro)

g) Fomentar o debate sobre a expansão de plantios de monoculturas que geram impacto no meio ambiente e na cultura dos povos e comunidades tradicionais, tais como eucalipto, canade-açúcar, soja, e sobre o manejo florestal, a grande pecuária, mineração, turismo e pesca.

Responsável: Secretaria Especial dos Direitos Humanos da Presidência da República

Parceiros: Ministério do Meio Ambiente; Ministério do Desenvolvimento Agrário; Fundação Nacional do Índio (Funai); Instituto Brasileiro do Meio Ambiente e dos Recursos Naturais Renováveis (IBAMA); Ministério da Agricultura, Pecuária e Abastecimento; Ministério da Ciência e Tecnologia; Ministério de Minas e Energia; Ministério do Turismo; Ministério da Pesca e Aquicultura

h) Erradicar o trabalho infantil, bem como todas as formas de violência e exploração sexual de crianças e adolescentes nas cadeias produtivas, com base em códigos de conduta e no Estatuto da Criança e do Adolescente.

Responsáveis: Secretaria Especial dos Direitos Humanos da Presidência da República; Ministério

do Turismo

Parceiros:Ministério do Desenvolvimento Social e Combate à Fome; Ministério da Educação; Ministério da Justiça; Ministério do Desenvolvimento, Indústria e Comércio Exterior; Secretaria-Geral da Presidência da República/Secretaria Nacional de Juventude; Secretaria Especial de Políticas para as Mulheres da Presidência da República

Recomendação: Recomenda-se aos estados, Distrito Federal e municípios ações de combate da exploração sexual de mulheres no turismo sexual.

i) Garantir que os grandes empreendimentos e os projetos de infraestrutura resguardem os direitos dos povos indígenas e de comunidades quilombolas e tradicionais, conforme previsto na Constituição e nos tratados e convenções internacionais. 
Nacional; Ministério de Minas e Energia; Secretaria Especial de Políticas de Promoção da Igualdade Racial da Presidência da República; Ministério do Meio Ambiente; Ministério do Desenvolvimento Social e Combate à Fome; Ministério da Pesca e Aquicultura; Secretaria Especial de Portos da Presidência da República

j) Integrar políticas de geração de emprego e renda e políticas sociais para o combate à pobreza rural dos agricultores familiares, assentados da reforma agrária, quilombolas, indígenas, famílias de pescadores e comunidades tradicionais.

Responsáveis: Ministério do Desenvolvimento Social e Combate à Fome; Ministério da IntegraçãoNacional; Ministério do Desenvolvimento Agrário; Ministério do Trabalho e Emprego; Ministério daJustiça, Secretaria Especial de Políticas de Promoção da Igualdade Racial da Presidência da República; Ministério da Cultura; Ministério da Pesca e Aquicultura Parceiros: Ministério da Ciência e Tecnologia; Ministério do Meio Ambiente; Empresa Brasileira de Pesquisa Agropecuária (Embrapa)

k) Integrar políticas sociais e de geração de emprego e renda para o combate à pobreza urbana, em especial de catadores de materiais recicláveis e população em situação de rua.

Responsáveis: Ministério do Trabalho e Emprego; Ministério do Meio Ambiente; Ministério do Desenvolvimento Social e Combate à Fome; Ministério das Cidades; Secretaria Especial dos Direitos Humanos da Presidência da República

Parceiros: Ministério da Ciência e Tecnologia; Ministério do Desenvolvimento, Indústria e Comércio

Exterior

1) Fortalecer políticas públicas de fomento à aquicultura e à pesca sustentáveis, com foco nos povos e comunidades tradicionais de baixa renda, contribuindo para a segurança alimentar e a inclusão social, mediante a criação e geração de trabalho e renda alternativos e inserção no mercado de trabalho.

Responsáveis: Ministério da Pesca e Aquicultura; Ministério do Trabalho e Emprego; Ministério do Desenvolvimento Social e Combate à Fome

Parceiros: Ministério da Ciência e Tecnologia; Ministério do Desenvolvimento Agrário; Ministério do Meio Ambiente

m) Promover o turismo sustentável com geração de trabalho e renda, respeito à cultura local, 
das comunidades nos benefícios advindos da atividade

turística.

Responsáveis: Ministério do Turismo; Ministério do Desenvolvimento, Indústria e Comércio Exterior

Parceiros: Secretaria Especial dos Direitos Humanos da Presidência da República; Ministério do Meio Ambiente; Ministério da Cultura; Ministério do Desenvolvimento Social e Combate à Fome; Secretaria-Geral da Presidência da República/Secretaria Nacional de Juventude; Instituto Nacional de Metrologia, Normalização e Qualidade Industrial (Inmetro)

Objetivo estratégico II:

Fortalecimento de modelos de agricultura familiar e agroecológica.

Ações programáticas:

a) Garantir que nos projetos de reforma agrária e agricultura familiar sejam incentivados os modelos de produção agroecológica e a inserção produtiva nos mercados formais.

Responsáveis: Ministério do Desenvolvimento Agrário; Ministério do Desenvolvimento, Indústria eComércio Exterior

Parceiros: Ministério do Meio Ambiente; Ministério da Ciência e Tecnologia; Empresa Brasileira de Pesquisa Agropecuária (Embrapa); Instituto Nacional de Metrologia, Normalização e Qualidade Industrial (Inmetro)

b) Fortalecer a agricultura familiar camponesa e a pesca artesanal, com ampliação do crédito, do seguro, da assistência técnica, extensão rural e da infraestrutura para a comercialização.

Responsáveis: Ministério do Desenvolvimento Agrário; Ministério da Pesca e Aquicultura

Parceiros: Ministério do Desenvolvimento Social e Combate à Fome; Ministério do Planejamento, Orçamento e Gestão; Ministério da Fazenda; Ministério do Desenvolvimento, Indústria e Comércio Exterior

c) Garantir pesquisa e programas voltados à agricultura familiar e pesca artesanal, com base nos princípios da agroecologia.

Responsáveis: Ministério do Desenvolvimento Agrário; Ministério do Meio Ambiente; Ministério da Agricultura, Pecuária e Abastecimento; Ministério da Pesca e Aquicultura; Ministério do Desenvolvimento, Indústria e Comércio Exterior

Parceiros: Ministério do Desenvolvimento Social e Combate à Fome; Ministério da Ciência e 
Metrologia, Normalização e Qualidade Industrial (Inmetro)

d) Fortalecer a legislação e a fiscalização para evitar a contaminação dos alimentos e danos à saúde e ao meio ambiente causados pelos agrotóxicos.

Responsáveis: Ministério da Agricultura, Pecuária e Abastecimento; Ministério do Meio Ambiente; Ministério da Saúde; Ministério do Desenvolvimento Agrário

e) Promover o debate com as instituições de ensino superior e a sociedade civil para a implementação de cursos e realização de pesquisas tecnológicas voltados à temática socioambiental, agroecologia e produção orgânica, respeitando as especificidades de cada região.

Responsáveis: Ministério da Educação; Ministério do Desenvolvimento Agrário Desenvolvimento e Direitos Humanos

Objetivo estratégico III:

Fomento à pesquisa e à implementação de políticas para o desenvolvimento de tecnologias socialmente inclusivas, emancipatórias e ambientalmente sustentáveis.

Ações programáticas:

a) Adotar tecnologias sociais de baixo custo e fácil aplicabilidade nas políticas e ações públicas para a geração de renda e para a solução de problemas socioambientais e de saúde pública.

Responsáveis: Ministério do Trabalho e Emprego; Ministério do Desenvolvimento Social e Combate à Fome; Ministério do Meio Ambiente; Ministério do Desenvolvimento Agrário; Ministério da Saúde

Parceiros: Ministério da Ciência e Tecnologia; Ministério do Desenvolvimento, Indústria e Comércio Exterior

b) Garantir a aplicação do princípio da precaução na proteção da agrobiodiversidade e da saúde, realizando pesquisas que avaliem os impactos dos transgênicos no meio ambiente e na saúde.

Responsáveis: Ministério da Saúde; Ministério do Meio Ambiente; Ministério de Ciência e Tecnologia

c) Fomentar tecnologias alternativas para substituir o uso de substâncias danosas à saúde e ao 
gânicos persistentes, metais pesados e outros poluentes inorgânicos.

Responsáveis: Ministério de Ciência e Tecnologia; Ministério do Meio Ambiente; Ministério da Saúde; Ministério da Agricultura, Pecuária e Abastecimento; Ministério do Desenvolvimento, Indústria e Comércio Exterior

Parceiros: Ministério do Desenvolvimento Agrário; Financiadora de Estudos e Projetos (Finep)

d) Fomentar tecnologias de gerenciamento de resíduos sólidos e emissões atmosféricas para minimizar impactos à saúde e ao meio ambiente.

Responsáveis: Ministério de Ciência e Tecnologia; Ministério do Meio Ambiente; Ministério da Saúde; Ministério das Cidades

Parceiros: Coordenação de Aperfeiçoamento de Pessoal de Nível Superior (Capes); Financiadora de Estudos e Projetos (Finep)

e) Desenvolver e divulgar pesquisas públicas para diagnosticar os impactos da biotecnologia e da nanotecnologia em temas de Direitos Humanos.

Responsáveis: Secretaria Especial dos Direitos Humanos da Presidência da República; Ministério da Saúde; Ministério do Meio Ambiente; Ministério da Agricultura, Pecuária e Abastecimento; Ministério de Ciência e Tecnologia

Parceiros: Ministério do Desenvolvimento, Indústria e Comércio Exterior; Financiadora de Estudos e Projetos (Finep)

f) Produzir, sistematizar e divulgar pesquisas econômicas e metodologias de cálculo de custos socioambientais de projetos de infraestrutura, de energia e de mineração que sirvam como parâmetro para o controle dos impactos de grandes projetos.

Responsáveis: Ministério de Ciência e Tecnologia; Ministério das Minas e Energia; Ministério do Meio Ambiente; Secretaria de Assuntos Estratégicos da Presidência da República; Ministério da Integração Nacional

Parceiros: Coordenação de Aperfeiçoamento de Pessoal de Nível Superior (Capes); Conselho Nacional de Desenvolvimento Científico e Tecnológico (CNPq); Instituto de Pesquisa Econômica Aplicada (Ipea); Financiadora de Estudos e Projetos (Finep)

Objetivo estratégico IV: 
as e sustentáveis.

Ações programáticas:

a) Apoiar ações que tenham como princípio o direito a cidades inclusivas e acessíveis como elemento fundamental da implementação de políticas urbanas.

Responsáveis: Ministério das Cidades; Secretaria Especial dos Direitos Humanos da Presidência da República; Ministério do Desenvolvimento, Indústria e Comércio Exterior

Parceiros: Secretaria de Relações Institucionais da Presidência da República; Secretaria Especial de Políticas para as Mulheres da Presidência da República; Instituto Nacional de Metrologia, Normalização e Qualidade Industrial (Inmetro)

b) Fortalecer espaços institucionais democráticos, participativos e de apoio aos municípios para a implementação de planos diretores que atendam aos preceitos da política urbana estabelecidos no Estatuto da Cidade.

Responsável: Ministério das Cidades

Recomendação: Recomenda-se ao Poder Judiciário a aplicação do conceito constitucional da função social da propriedade.

c) Fomentar políticas públicas de apoio aos estados, Distrito Federal e municípios em ações sustentáveis de urbanização e regularização fundiária dos assentamentos de população de baixa renda, comunidades pesqueiras e de provisão habitacional de interesse social, materializando a função social da propriedade.

Responsáveis: Ministério das Cidades; Ministério do Meio Ambiente; Ministério da Pesca e Aquicultura

Parceiros: Ministério do Desenvolvimento Agrário; Secretaria de Relações Institucionais da Presidência da República

d) Fortalecer a articulação entre os órgãos de governo e os consórcios municipais para atuar na política de saneamento ambiental, com participação da sociedade civil.

Responsáveis: Ministério das Cidades; Ministério do Meio Ambiente; Secretaria de Relações Institucionais da Presidência da República

e) Fortalecer a política de coleta, reaproveitamento, triagem, reciclagem e a destinação seletiva de resíduos sólidos e líquidos, com a organização de cooperativas de reciclagem,que beneficiem as famílias dos catadores. 
es; Ministério do Trabalho e Emprego; Ministério do Desenvolvimento Social e Combate à Fome; Ministério do Meio Ambiente

Parceiros: Secretaria de Relações Institucionais da Presidência da República; Ministério do Desenvolvimento, Indústria e Comércio Exterior

Recomendação: Recomenda-se aos estados a assinatura de convênios para implementação dos planos estaduais de gestão integrada de resíduos sólidos.

f) Fomentar políticas e ações públicas voltadas à mobilidade urbana sustentável.

\section{Responsável: Ministério das Cidades}

Parceiros: Secretaria Especial dos Direitos Humanos da Presidência da República; Secretaria de Relações Institucionais da Presidência da República; Ministério do Desenvolvimento, Indústria e Comércio Exterior

g) Considerar na elaboração de políticas públicas de desenvolvimento urbano os impactos na saúde pública.

Responsáveis: Ministério da Saúde; Ministério das Cidades

h) Fomentar políticas públicas de apoio às organizações de catadores de materiais recicláveis, visando à disponibilização de áreas e prédios desocupados pertencentes à União, a fim de serem transformados em infraestrutura produtiva para essas organizações.

Responsáveis: Ministério do Planejamento, Orçamento e Gestão; Ministério das Cidades; Ministériodo Trabalho e Emprego; Ministério do Desenvolvimento Social e Combate à Fome

i) Estimular a produção de alimentos de forma comunitária, com uso de tecnologias de bases agroecológicas, em espaços urbanos e periurbanos ociosos e fomentar a mobilização comunitária para a implementação de hortas, viveiros, pomares, canteiros de ervas medicinais, criação de pequenos animais, unidades de processamento e beneficiamento agroalimentar, feiras e mercados públicos populares.

Responsáveis: Ministério do Desenvolvimento Social e Combate à Fome; Ministério da Agricultura,

Pecuária e Abastecimento

Parceiro: Empresa Brasileira de Pesquisa Agropecuária (Embrapa)

\section{Diretriz 5:}

Valorização da pessoa humana como sujeito central do processo de desenvolvimento. 
Garantia da participação e do controle social nas políticas públicas de desenvolvimento com grande impacto socioambiental.

Ações programáticas:

a) Fortalecer ações que valorizem a pessoa humana como sujeito central do desenvolvimento, enfrentando o quadro atual de injustiça ambiental que atinge principalmente as populações mais pobres.

Responsáveis: Secretaria Especial dos Direitos Humanos da Presidência da República; Ministério do Meio Ambiente

b) Assegurar participação efetiva da população na elaboração dos instrumentos de gestão territorial e na análise e controle dos processos de licenciamento urbanístico e ambiental de empreendimentos de impacto, especialmente na definição das ações mitigadoras e compensatórias por impactos sociais e ambientais.

Responsáveis: Ministério do Meio Ambiente; Ministério das Cidades

Parceiros: Ministério de Minas e Energia; Casa Civil da Presidência da República; Ministério dos Transportes; Secretaria-Geral da Presidência da República

c) Fomentar a elaboração do Zoneamento Econômico Ecológico (ZEE), incorporando o sócio e etnozoneamento.

Responsáveis: Ministério das Cidades; Ministério do Meio Ambiente

Parceiros: Ministério da Integração Nacional; Ministério do Desenvolvimento Agrário

d) Assegurar a transparência dos projetos realizados, em todas as suas etapas, e dos recursos utilizados nos grandes projetos econômicos, para viabilizar o controle social.

Responsáveis: Ministério dos Transportes; Ministério da Integração Nacional; Ministério de Minas e Energia; Secretaria Especial dos Direitos Humanos da Presidência da República

Parceiros: Casa Civil da Presidência da República; Controladoria-Geral da União

e) Garantir a exigência de capacitação qualificada e participativa das comunidades afetadas nos projetos básicos de obras e empreendimentos com impactos sociais e ambientais.

Responsáveis: Ministério da Integração Nacional; Ministério de Minas e Energia; Secretaria Especial dos Direitos Humanos da Presidência da República 
República

f) Definir mecanismos para a garantia dos Direitos Humanos das populações diretamente atingidas e vizinhas aos empreendimentos de impactos sociais e ambientais.

Responsável: Secretaria Especial dos Direitos Humanos da Presidência da República

Parceiros: Ministério do Desenvolvimento Social e Combate à Fome; Casa Civil da Presidência da República; Secretaria-Geral da Presidência da República; Ministério de Minas e Energia; Ministério dos Transportes; Secretaria Especial de Portos da Presidência da República

g) Apoiar a incorporação dos sindicatos de trabalhadores e centrais sindicais nos processos de licenciamento ambiental de empresas, de forma a garantir o direito à saúde do trabalhador.

Responsáveis: Ministério do Meio Ambiente; Ministério do Trabalho e Emprego; Ministério da Saúde

h) Promover e fortalecer ações de proteção às populações mais pobres da convivência com áreas contaminadas, resguardando-as contra essa ameaça e assegurando-lhes seus direitos fundamentais.

Responsáveis: Ministério do Meio Ambiente; Ministério das Cidades; Ministério do Desenvolvimento Social e Combate à Fome; Ministério da Saúde

Objetivo estratégico II:

Afirmação dos princípios da dignidade humana e da equidade como fundamentos do processo de desenvolvimento nacional.

Ações programáticas:

a) Reforçar o papel do Plano Plurianual (PPA) como instrumento de consolidação dos Direitos Humanos e de enfrentamento da concentração de renda e riqueza e de promoção da inclusão da população de baixa renda.

Responsável: Ministério do Planejamento, Orçamento e Gestão

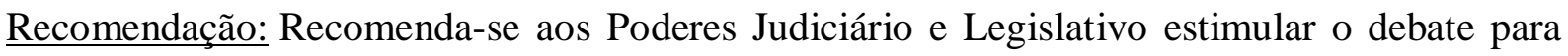
revisão dos procedimentos adotados na etapa legislativa do processo orçamentário, possibilitando maior envolvimento da sociedade nas discussões sobre as prioridades de uso dos recursos públicos. 
na avaliação da programação orçamentária de ação ou autorização de gastos.

Responsável: Ministério do Planejamento, Orçamento e Gestão

c) Instituir um código de conduta em Direitos Humanos para ser considerado no âmbito do poder público como critério para a contratação e financiamento de empresas.

Responsável: Secretaria Especial dos Direitos Humanos da Presidência da República

Parceiro: Casa Civil da Presidência da República

d) Regulamentar a taxação do imposto sobre grandes fortunas previsto na Constituição.

Responsáveis: Ministério da Fazenda; Secretaria Especial dos Direitos Humanos da Presidência da República

Parceiros: Ministério do Desenvolvimento Social e Combate à Fome; Secretaria de Relações Institucionais da Presidência da República

Recomendação: Recomenda-se ao Poder Legislativo que legisle sobre o imposto sobre grandes fortunas.

e) Ampliar a adesão de empresas ao compromisso de responsabilidade social e Direitos Humanos.

Responsável: Secretaria Especial dos Direitos Humanos da Presidência da República; Ministério do Desenvolvimento, Indústria e Comércio Exterior

Parceiros: Ministério do Turismo; Ministério do Desenvolvimento Social e Combate à Fome;

Objetivo estratégico III:

Fortalecimento dos direitos econômicos por meio de políticas públicas de defesa da concorrência e de proteção do consumidor.

Ações programáticas:

a) Garantir o acesso universal a serviços públicos essenciais de qualidade.

Responsáveis: Ministério da Saúde; Ministério da Educação; Ministério de Minas e Energia; Ministério do Desenvolvimento Social e Combate à Fome; Ministério das Cidades

Recomendação: Recomenda-se aos estados e municípios a ampliação da garantia ao acesso universal a serviços públicos essenciais de qualidade. 
anticompetitivas e concentradoras de renda.

Responsáveis: Ministério da Justiça; Ministério da Fazenda

c) Garantir o direito à informação do consumidor, fortalecendo as ações de acompanhamento de mercado, inclusive a rotulagem dos transgênicos.

Responsáveis: Ministério da Justiça; Ministério do Desenvolvimento, Indústria e Comércio Exterior; Ministério da Agricultura, Pecuária e Abastecimento

Parceiros: Ministério das Comunicações; Agências reguladoras

Recomendação: Recomenda-se aos estados, por meio dos Procons, garantir o direito à informação do consumidor, fortalecendo as ações de fiscalização de especificações técnicas, inclusive a rotulagem dos transgênicos.

d) Fortalecer o combate à fraude e a avaliação da conformidade dos produtos e serviços no mercado.

Responsáveis: Ministério da Justiça; Ministério do Desenvolvimento, Indústria e Comércio Exterior

Parceiros: Agências reguladoras

Recomendação: Recomenda-se aos estados, por meio dos Procons, o fortalecimento do combate à fraude e o controle de qualidade dos produtos e serviços no mercado.

Diretriz 6:

Promover e proteger os direitos ambientais como Direitos Humanos, incluindo as gerações futuras como sujeitos de direitos.

Objetivo estratégico I:

Afirmação dos direitos ambientais como Direitos Humanos.

Ações programáticas:

a) Incluir o item Direito Ambiental nos relatórios de monitoramento dos Direitos Humanos.

Responsáveis: Secretaria Especial dos Direitos Humanos da Presidência da República; Ministério do Meio Ambiente

b) Incluir o tema dos Direitos Humanos nos instrumentos e relatórios dos órgãos ambientais. 
Ministério do Meio Ambiente

c) Assegurar a proteção dos direitos ambientais e dos Direitos Humanos no Código Florestal.

Responsável: Ministério do Meio Ambiente

d) Implementar e ampliar políticas públicas voltadas para a recuperação de áreas degradadas e áreas de desmatamento nas zonas urbanas e rurais.

Responsáveis: Ministério do Meio Ambiente; Ministério das Cidades

Parceiro: Ministério da Agricultura, Pecuária e Abastecimento

Recomendação: Recomendam-se aos estados a implementação e a ampliação de políticas públicas voltadas para a recuperação de áreas degradadas e de desmatamento nas zonas urbanas e rurais.

e) Fortalecer ações que estabilizem a concentração de gases de efeito estufa em um nível que permita a adaptação dos ecossistemas à mudança do clima, controlando a interferência das atividades humanas (antrópicas) no sistema climático.

Responsável: Ministério do Meio Ambiente

f) Garantir o efetivo acesso à informação sobre a degradação e os riscos ambientais, e ampliar e articular as bases de informações dos entes federados e produzir informativos em linguagem acessível.

\section{Responsável: Ministério do Meio Ambiente}

Parceiro: Secretaria de Relações Institucionais da Presidência da República

Recomendação: Recomenda-se ao Ministério Público garantir o efetivo acesso à informação sobre degradação e riscos ambientais, ampliando e articulando as bases de informações de todos os entes federados e produzindo informativos em linguagem acessível.

g) Integrar os atores envolvidos no combate ao trabalho escravo nas operações correntes de fiscalização ao desmatamento e ao corte ilegal de madeira.

Responsáveis: Secretaria Especial dos Direitos Humanos da Presidência da República; Ministério do Trabalho e Emprego; Ministério do Meio Ambiente 


\section{intas realizadas nas entrevistas}

Pergunta 1: Você participou da formulação do PNDH-3. Você poderia dizer em que medida participou, que cargo exercia e onde trabalhava? Poderia também descrever como os eixos e ações foram elaborados e como você contribuiu a esse processo?

Pergunta 2: Especificamente com relação ao Eixo 2 do Programa, Desenvolvimento e Direitos Humanos, você poderia relatar algo que se lembre da formulação desse Eixo?

Pergunta 3: Como é sabido, o PNDH-3 sofreu diversas críticas, de setores políticos, jornalísticos, de juristas e partidas do próprio Estado. Questões de gênero, participação social, laicidade do Estado, igualdade racial foram duramente atacadas. Contudo, não se viu com a mesma expressão críticas específicas, dirigidas ao direito ao desenvolvimento. Você poderia apontar possíveis razões para isso?

Pergunta 4: O nome de Amartya Sen aparece na introdução do Eixo Desenvolvimento e Direitos Humanos. Ele é o único autor nominalmente citado no texto do Programa. Você sabe apontar alguma razão para esse reconhecimento?

Pergunta 5: Nas ações (d) a (f) do Objetivo Estratégico 1 da Diretriz 5 do Eixo Desenvolvimento e direitos Humanos, aparecem algumas questões relativas a consulta, participação e transparência de consulta a populações atingidas por grandes obras. Saberia dizer as razões dessas ações constarem do texto?

Pergunta 6: Como você avalia a inclusão no texto de políticas de inclusão de renda e políticas de erradicação de pobreza rural em comunidades tradicionais, quilombolas e indígenas?

Pergunta 7: Houve alguma divergência dentro do governo com relação a esse Eixo, Desenvolvimento e Direitos Humanos?

Pergunta 8: Uma das ações previstas na Diretriz 5, objetivo estratégico 2, há a previsão de considerar critérios de equidade e prevalência de direitos humanos da avaliação orçamentária e previsão de gastos. O que se imaginou ao inserir tal ação?

Pergunta 9: Esteja à vontade para tecer comentários, impressões e reflexões sobre o processo de formulação e o texto do Programa. 